\title{
Risk Assessment for the Off-Site Transportation of High-Level Waste for the U.S. Department of Energy Waste Management Programmatic Environmental Impact Statement
}

by F.A. Monette, B.M. Biwer, D.J. LePoire, and S.Y. Chen

Environmental Assessment Division,

Argonne National Laboratory, 9700 South Cass Avenue, Argonne, Illinois 60439

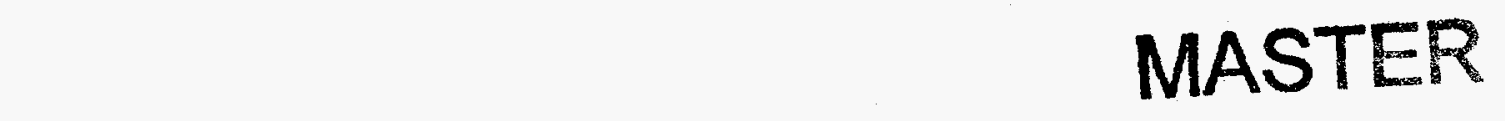

December 1996

Work sponsored by United States Department of Energy, Assistant Secretary for Environmental Management 


\section{DISCLAIMER}

This report was prepared as an account of work sponsored by an agency of the United States Government. Neither the United States Government nor any agency thereof, nor any of their employees, make any warranty, express or implied, or assumes any legal liabiitty or responsibility for the accuracy, completeness, or usefulness of any information, appa. ratus, product, or process disclosed, or represents that its use would not iniringe privately owned rights. Reference herein to any specific commercial product, process, or service by trade name, trademark, manufacturer, or otherwise does not necessarily constitute or imply its endorsement, recommendation, or favoring by the United States Government or any agency thereof. The views and opinions of authors expressed herein do not necescarily state or reflect those of the United States Government or any agency thereof. 


\section{DISCLAIMER}

Portions of this document may be illegible electronic image products. Images are produced from the best available original document. 


\section{CONTENTS}

NOTATION

ABSTRACT

1 INTRODUCTION

2 SCOPE OF ASSESSMENT

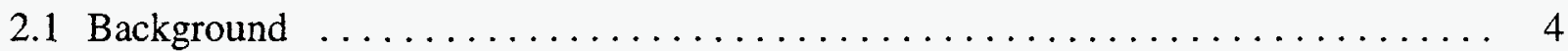

2.2 High-Level Waste Inventory and Characteristics $\ldots \ldots \ldots \ldots \ldots \ldots \ldots \ldots \ldots$

2.2.1 Hanford Site ................................ 5

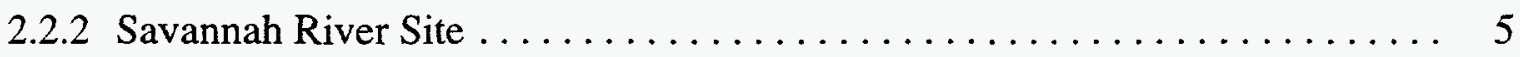

2.2.3 Idaho National Engineering Laboratory $\ldots \ldots \ldots \ldots \ldots \ldots \ldots \ldots \ldots$

2.2.4 West Valley Demonstration Project ..................... 6

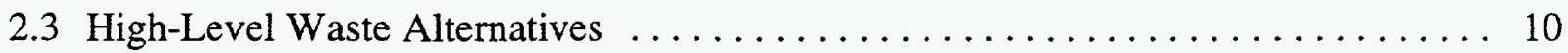

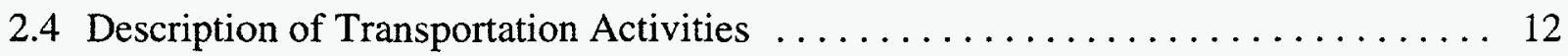

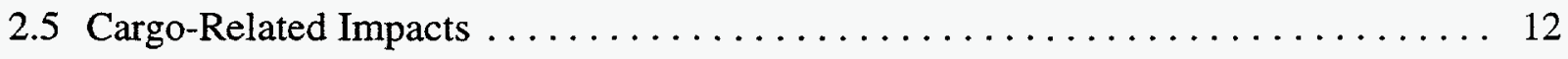

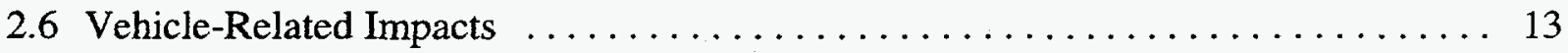

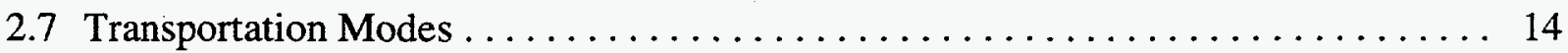

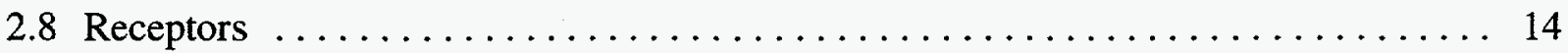

3 PACKAGING REGULATIONS AND ASSUMPTIONS .................. 15

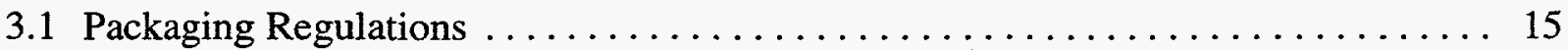

3.2 Packaging Assumptions $\ldots \ldots \ldots \ldots \ldots \ldots \ldots \ldots \ldots \ldots \ldots \ldots \ldots \ldots \ldots \ldots \ldots \ldots$

4 ANALYSIS OF TRUCK AND RAIL ROUTING $\ldots \ldots \ldots \ldots \ldots \ldots \ldots \ldots \ldots$

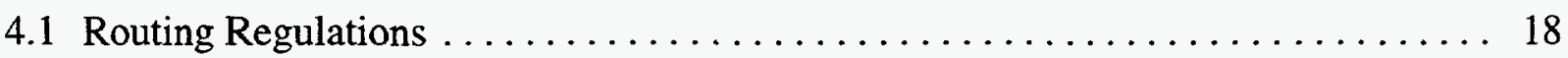

4.2 Representative Transportation Routes $\ldots \ldots \ldots \ldots \ldots \ldots \ldots \ldots \ldots \ldots \ldots \ldots \ldots \ldots \ldots \ldots \ldots$

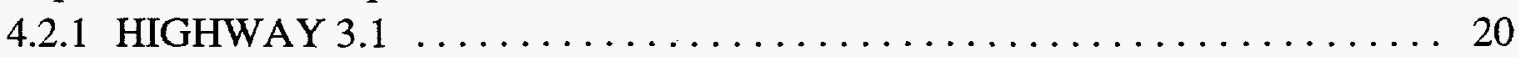

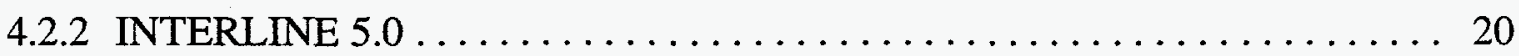

5 METHODS FOR CALCULATING TRANSPORTATION-RELATED RISKS $\ldots \ldots \ldots 22$

5.1 Routine Risk Assessment Method .......................... 24

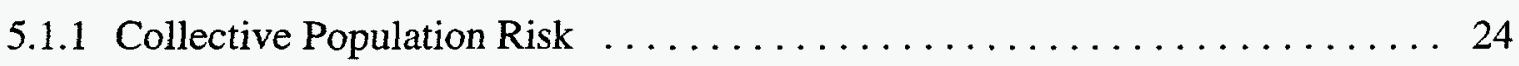

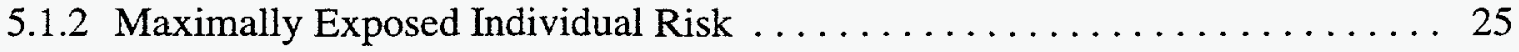

5.1 .3 Vehicle-Related Routine Risk ...................... 26 


\section{CONTENTS (Cont.)}

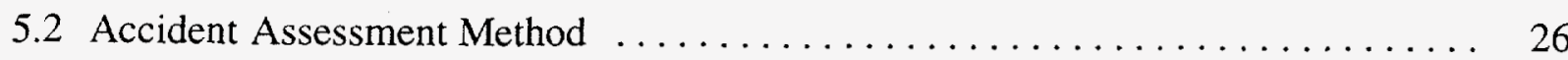

5.2.1 Radiological Accident Risk Assessment . . . . . . . . . . . . . . . . 26

5.2.2 Radiological Accident Consequence Assessment .............. 28

5.2.3 Vehicle-Related Accident Risk Assessment . . . . . . . . . . . . . . . . . 29

6 INPUT PARAMETERS AND ASSUMPTIONS $\ldots \ldots \ldots \ldots \ldots \ldots \ldots \ldots \ldots$

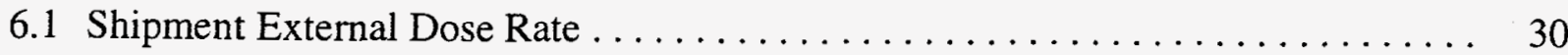

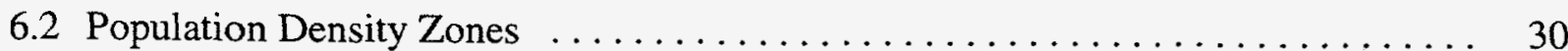

6.3 Accident Rates .................................... 31

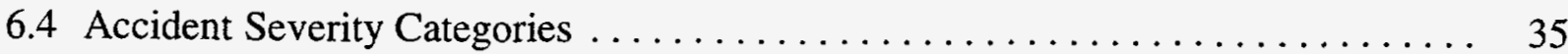

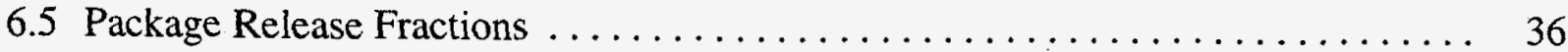

6.6 Atmospheric Conditions .................................. 38

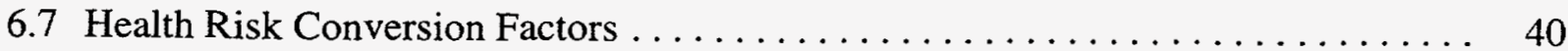

6.8 Maximally Exposed Individual Exposure Scenarios $\ldots \ldots \ldots \ldots \ldots \ldots \ldots .41$

6.9 General RADTRAN Input Parameters . . . . . . . . . . . . . . . . . 42

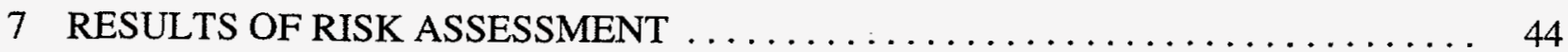

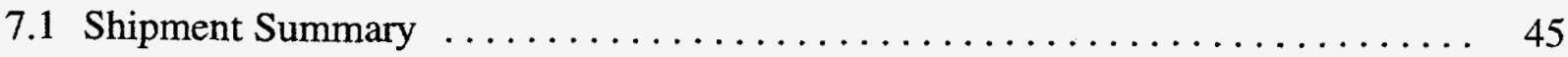

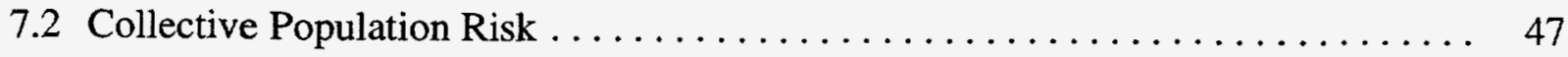

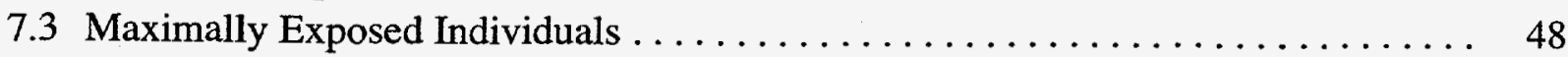

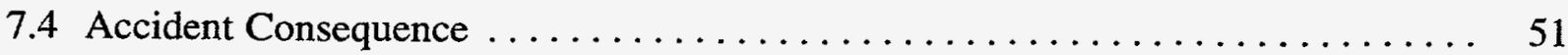

8 UNCERTAINTIES AND CONSERVATISM IN ESTIMATED IMPACTS $\ldots \ldots \ldots \ldots 53$

8.1 Uncertainties in Waste Inventory and Characterization $\ldots \ldots \ldots \ldots \ldots \ldots \ldots . \ldots \ldots$

8.2 Uncertainties in Shipment Capacities . . . . . . . . . . . . . . . . . . 54

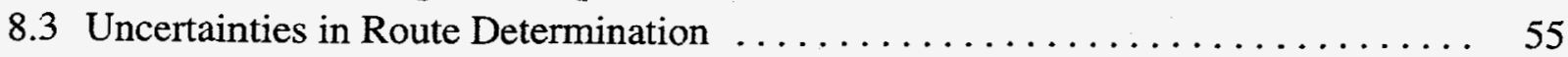

8.4 Uncertainties in Calculation of Radiation Doses ................ 55

8.5 Uncertainties in Comparison of Truck and Rail Transportation Modes ....... 57

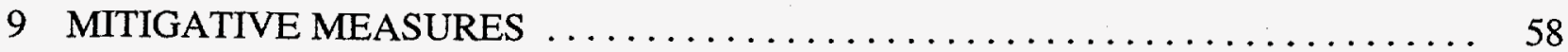

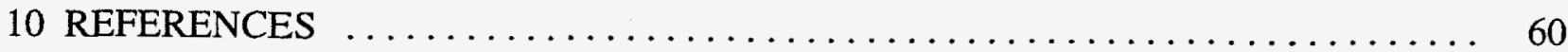

APPENDIX: Detailed Collective Risk Results by Alternative $\ldots \ldots \ldots \ldots \ldots \ldots$ A-1 


\section{FIGURES}

5.1 Technical Approach for the HLW Transportation Radiological Risk Assessment . . . 23

6.1 Scheme for NUREG-0170 Classification by Accident

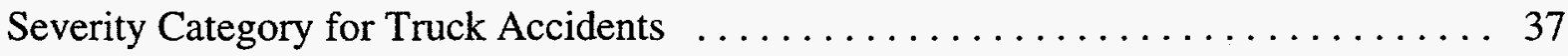

6.2 Scheme for NUREG-0170 Classification by Accident

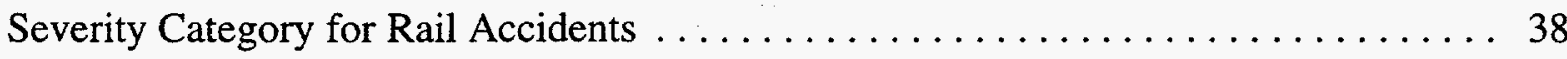

\section{TABLES}

2.1 Projected Number of Canisters of HLW Produced at Each Site $\ldots \ldots \ldots \ldots \ldots \ldots$

2.2 Estimated Major Radionuclide Content per HLW Canister $\ldots \ldots \ldots \ldots \ldots \ldots \ldots$

2.3 Summary of HLW Transportation Analyzed in the WM PEIS $\ldots \ldots \ldots \ldots \ldots \ldots$

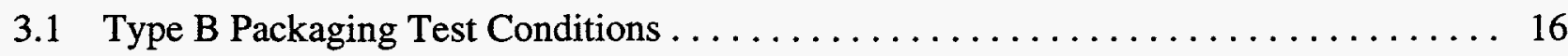

4.1 Route Summary Information for HLW Shipments Considered in the WM PEIS ..... 19

6.1 Highway Combination-Truck Accident, Fatality, and Injury Rates by Road Type Based on Reportable Interstate-Carrier Accidents, Reported Fatalities and Injuries, and Estimated Flows, 1986-1988

6.2 Railroad-Freight-Car Accident Rates, by State, for 1986, 1987, 1988, and 1985-1988 Combined

6.3 Fractional Occurrences for Accidents by Severity Category and Population Density Zone . . . . . . . . . . . . . . . . . . . . . . 39

6.4 Estimated Release Fractions for HLW Shipping Cask under Various Accident Severity Categories

6.5 General RADTRAN Input Parameters $\ldots \ldots \ldots \ldots \ldots \ldots \ldots \ldots \ldots \ldots \ldots \ldots \ldots$

7.1 Summary of Total Population Impacts of HLW Transportation:

Truck Mode 


\section{TABLES (Cont.)}

7.2 Summary of Total Population Impacts of HLW Transportation:

Rail Mode $\ldots \ldots \ldots \ldots \ldots \ldots \ldots \ldots \ldots \ldots \ldots \ldots \ldots \ldots, 47$

7.3 Estimated Routine Doses and Lifetime Risk of Fatal Cancer to MEIs

from Shipments of HLW $\ldots \ldots \ldots \ldots \ldots \ldots \ldots \ldots \ldots \ldots \ldots \ldots \ldots \ldots \ldots$

7.4 Cumulative Estimated Routine Dose and Lifetime Risk to a Resident

Living along a Site Entrance Route $\ldots \ldots \ldots \ldots \ldots \ldots \ldots \ldots \ldots \ldots, 50$

7.5 Estimated Consequences for the Most Severe Accidents Involving

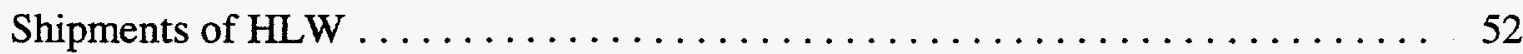

A.1-1 Summary of Route Information for the HLW No Action Alternative $\ldots \ldots \ldots \ldots$ A-4

A.1-2 Number of Shipments and Total One-Way Shipment Distances for the HLW

No Action Alternative $\ldots \ldots \ldots \ldots \ldots \ldots \ldots \ldots \ldots \ldots \ldots \ldots \ldots . \ldots \ldots$

A.1-3 Incident-Free Dose per Shipment for the HLW No Action Alternative $\ldots \ldots \ldots$ A-5

A.1-4 Accident Dose Risk per Shipment for the HLW No Action Alternative . . . . . . A A-5

A.1-5 Nonradiological Risk Factors per Shipment for

the $\mathrm{HLW}$ No Action Alternative $\ldots \ldots \ldots \ldots \ldots \ldots \ldots \ldots \ldots \ldots \ldots$

A.1-6 Total Incident-Free Dose for the HLW No Action Alternative $\ldots \ldots \ldots \ldots \ldots$ A-6

A.1-7 Total Accident Dose Risk for the HLW No Action Alternative $\ldots \ldots \ldots \ldots \ldots$ A-6

A.1-8 Expected Fatalities for the HLW No Action Alternative $\ldots \ldots \ldots \ldots \ldots \ldots$ A-7

A.1-9 Expected Cancer Incidence for the HLW No Action Alternative $\ldots \ldots \ldots \ldots$ A-7

A.1-10 Expected Genetic Effects for the HLW No Action Alternative $\ldots \ldots \ldots \ldots \ldots$ A-8

A.2-1 Summary of Route Information for the HLW Decentralized Alternative $\ldots \ldots \ldots$ A-9

A.2-2 Number of Shipments and Total One-Way Shipment Distances for the HLW

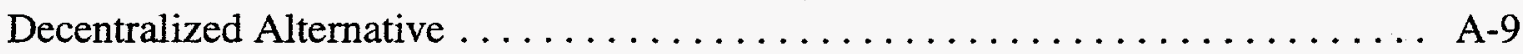




\section{TABLES (Cont.)}

A.2-3 Incident-Free Dose per Shipment for the HLW Decentralized Alternative . . . . A A-10

A.2-4 Accident Dose Risk per Shipment for the HLW Decentralized Alternative . . . . A A-11

A.2-5 Nonradiological Risk Factors per Shipment for the HLW

Decentralized Alternative $\ldots \ldots \ldots \ldots \ldots \ldots \ldots \ldots \ldots \ldots \ldots \ldots \ldots \ldots \ldots$

A.2-6 Total Incident-Free Dose for the HLW Decentralized Alternative $\ldots \ldots \ldots \ldots$ A-12

A.2-7 Total Accident Dose Risk for the HLW Decentralized Alternative . . . . . . . . . A-12

A.2-8 Expected Fatalities for the HLW Decentralized Alternative $\ldots \ldots \ldots \ldots \ldots \ldots$ A-13

A.2-9 Expected Cancer Incidence for the HLW Decentralized Alternative . . . . . . . A A-13

A.2-10 Expected Genetic Effects for the HLW Decentralized Alternative . . . . . . . . A A-14

A.3-1 Summary of Route Information for the HLW Regionalized 1 Alternative . . . . . A-15

A.3-2 Number of Shipments and Total One-Way Shipment Distances for the HLW

Regionalized 1 Alternative . . . . . . . . . . . . . . . . .

A.3-3 Incident-Free Dose per Shipment for the HLW Regionalized 1 Alternative $\ldots$ A-16

A.3-4 Accident Dose Risk per Shipment for the HLW Regionalized 1 Alternative .... A-17

A.3-5 Nonradiological Risk Factors per Shipment for the HLW

Regionalized 1 Alternative $\ldots \ldots \ldots \ldots \ldots \ldots \ldots \ldots \ldots \ldots \ldots \ldots \ldots \ldots \ldots$

A.3-6 Total Incident-Free Dose for the HLW Regionalized 1 Alternative $\ldots . \ldots \ldots$ A-18

A.3-7 Total Accident Dose Risk for the HLW Regionalized 1 Alternative . . . . . . . . A-18

A.3-8 Expected Fatalities for the HLW Regionalized 1 Alternative $\ldots \ldots \ldots \ldots \ldots$. . . .

A.3-9 Expected Cancer Incidence for the HLW Regionalized 1 Alternative . . . . . . . A A-19

A.3-10 Expected Genetic Effects for the HLW Regionalized 1 Alternative . . . . . . . A-20 


\section{TABLES (Cont.)}

A.4-1 Summary of Route Information for the HLW Regionalized 2 Alternative . . . . . A-21

A.4-2 Number of Shipments and Total One-Way Shipment Distances for the HLW

Regionalized 2 Alternative $\ldots \ldots \ldots \ldots \ldots \ldots \ldots \ldots \ldots \ldots \ldots \ldots \ldots \ldots \ldots \ldots \ldots \ldots$

A.4-3 Incident-Free Dose per Shipment for the HLW Regionalized 2 Alternative . . . . A A-22

A.4-4 Accident Dose Risk per Shipment for the HLW Regionalized 2 Alternative .... A-23

A.4-5 Nonradiological Risk Factors per Shipment for the HLW Regionalized 2

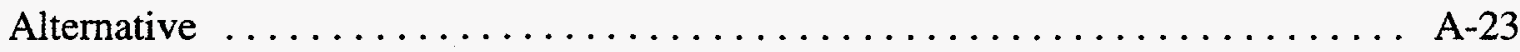

A.4-6 Total Incident-Free Dose for the HLW Regionalized 2 Alternative $\ldots \ldots \ldots$. . A 24

A.4-7 Total Accident Dose Risk for the HLW Regionalized 2 Alternative . . . . . . . . A-24

A.4-8 Expected Fatalities for the HLW Regionalized 2 Alternative . . . . . . . . . A A-25

A.4-9 Expected Cancer Incidence for the HLW Regionalized 2 Alternative $\ldots . . .$. A-25

A.4-10 Expected Genetic Effects for the HLW Regionalized 2 Alternative . . . . . . . A-26

A.5-1 Summary of Route Information for the HLW Centralized 1 Alternative . . . . . . A-27

A.5-2 Number of Shipments and Total One-Way Shipment Distances for the HLW

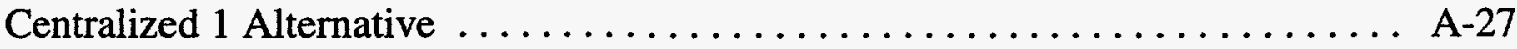

A.5-3 Incident-Free Dose per Shipment for the HLW Centralized 1 Alternative $\ldots \ldots$ A-28

A.5-4 Accident Dose Risk per Shipment for the HLW Centralized 1 Alternative . . . . . A-29

A.5-5 Nonradiological Risk Factors per Shipment for the HLW Centralized 1

Alternative . ............................... A-29

A.5-6 Total Incident-Free Dose for the HLW Centralized 1 Alternative . . . . . . . . A A-30

A.5-7 Total Accident Dose Risk for the HLW Centralized 1 Alternative . . . . . . . . . A-30

A.5-8 Expected Fatalities for the HLW Centralized 1 Alternative $\ldots \ldots \ldots \ldots \ldots \ldots$ A-31 


\section{TABLES (Cont.)}

A.5-9 Expected Cancer Incidence for the HLW Centralized 1 Alternative $\ldots \ldots \ldots \ldots$ A-31

A.5-10 Expected Genetic Effects for the HLW Centralized 1 Alternative .......... A-32

A.6-1 Summary of Route Information for the HLW Centralized 2 Alternative . . . . . . A A-33

A.6-2 Number of Shipments and Total One-Way Shipment Distances for the

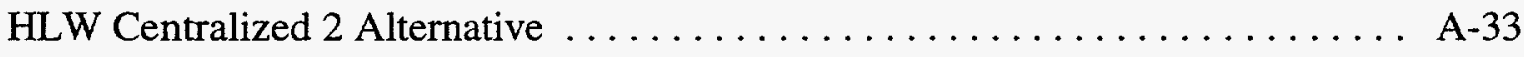

A.6-3 Incident-Free Dose per Shipment for the HLW Centralized 2 Alternative $\ldots \ldots$ A-34

A.6-4 Accident Dose Risk per Shipment for the HLW Centralized 2 Alternative ...... A-35

A.6-5 Nonradiological Risk Factors per Shipment for the HLW

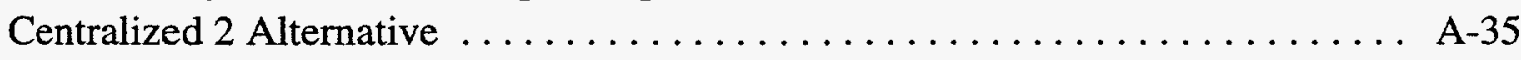

A.6-6 Total Incident-Free Dose for the HLW Centralized 2 Alternative $\ldots \ldots \ldots \ldots$ A-36

A.6-7 Total Accident Dose Risk for the HLW Centralized 2 Alternative...$\ldots \ldots$ A-36

A.6-8 Expected Fatalities for the HLW Centralized 2 Alternative $\ldots \ldots \ldots \ldots \ldots$ A-37

A.6-9 Expected Cancer Incidence for the HLW Centralized 2 Alternative $\ldots \ldots \ldots \ldots$ A-37

A.6-10 Expected Genetic Effects for the HLW Centralized 2 Alternative ........... A-38 


\section{NOTATION}

The following is a list of the acronyms, initialisms, and abbreviations (including units of measure) used in this document.

\section{ACRONYMS, INITIALISMS, and ABBREVIATIONS}

\begin{tabular}{ll}
$\mathrm{Ac}$ & actinium \\
$\mathrm{Ag}$ & silver \\
$\mathrm{Am}$ & americium \\
$\mathrm{At}$ & astatine \\
$\mathrm{Ba}$ & barium \\
$\mathrm{Bi}$ & bismuth \\
$\mathrm{Cd}$ & cadmium \\
$\mathrm{Ce}$ & cerium \\
$\mathrm{CFR}$ & Code of Federal Regulations \\
$\mathrm{Cm}$ & curium \\
$\mathrm{Co}$ & cobalt \\
$\mathrm{Cs}$ & cesium \\
$\mathrm{DHLW}$ & defense high-level waste \\
$\mathrm{DOE}$ & U.S. Department of Energy \\
$\mathrm{DOT}$ & U.S. Department of Transportation \\
$\mathrm{DST}$ & double-shell tank \\
$\mathrm{DWPF}$ & Defense Waste Processing Facility \\
Eu & europium \\
Fe & iron \\
Fr & francium \\
Gd & gadolinium \\
Hanford & Hanford Site \\
HLW & high-level waste \\
HWVP & Hanford Waste Vitrification Plant \\
I & iodine \\
ICRP & International Commission on Radiological Protection \\
In & indium \\
INEL & Idaho National Engineering Laboratory \\
MEI & maximally exposed individual \\
Nb & niobium \\
Nd & neodymium \\
NEPA & National Environmental Policy Act \\
Ni & nickel \\
& \\
\hline
\end{tabular}




\begin{tabular}{|c|c|}
\hline $\mathrm{Np}$ & neptunium \\
\hline NRC & U.S. Nuclear Regulatory Commission \\
\hline $\mathrm{Pa}$ & protactinium \\
\hline $\mathrm{Pb}$ & lead \\
\hline Pd & palladium \\
\hline $\mathrm{Pm}$ & promethium \\
\hline Po & polonium \\
\hline $\operatorname{Pr}$ & praseodymium \\
\hline $\mathrm{Pu}$ & plutonium \\
\hline $\mathrm{Ra}$ & radium \\
\hline $\mathrm{Rb}$ & rubidium \\
\hline $\mathrm{Rh}$ & rhodium \\
\hline $\mathrm{Rn}$ & radon \\
\hline $\mathrm{Ru}$ & ruthenium \\
\hline $\mathrm{Sb}$ & antimony \\
\hline $\mathrm{Se}$ & selenium \\
\hline $\mathrm{Sm}$ & samarium \\
\hline Sn & tin \\
\hline SNF & spent nuclear fuel \\
\hline $\mathrm{Sr}$ & strontium \\
\hline SRS & Savannah River Site \\
\hline SST & single-shell tank \\
\hline $\mathrm{Tb}$ & terbium \\
\hline Tc & technetium \\
\hline $\mathrm{Te}$ & tellurium \\
\hline Th & thorium \\
\hline $\mathrm{Tl}$ & thallium \\
\hline TRUW & transuranic waste \\
\hline $\mathrm{U}$ & uranium \\
\hline WIPP & Waste Isolation Pilot Plant \\
\hline WM PEIS & Waste Management Programmatic Environmental Impact Statement \\
\hline WVDP & West Valley Demonstration Project \\
\hline $\mathbf{Y}$ & yttrium \\
\hline $\mathrm{Zr}$ & zirconium \\
\hline
\end{tabular}

\section{UNITS OF MEASURE}

$\begin{array}{ll}{ }^{\circ} \mathrm{C} & \text { degree(s) Celsius } \\ \mathrm{Ci} & \text { curie(s) } \\ \mathrm{cm} & \text { centimeter(s) } \\ { }^{\circ} \mathrm{F} & \text { degree(s) Fahrenheit }\end{array}$




$\begin{array}{ll}\mathrm{ft} & \text { foot (feet) } \\ \mathrm{gal} & \text { gallon(s) } \\ \mathrm{h} & \text { hour(s) } \\ \mathrm{in.} & \text { inch(es) } \\ \mathrm{km} & \text { kilometer(s) } \\ \mathrm{km}^{2} & \text { square kilometer(s) } \\ \mathrm{L} & \text { liter(s) } \\ \mathrm{m} & \text { meter(s) } \\ \mathrm{m}^{3} & \text { cubic meter(s) } \\ \mathrm{mi} & \text { mile(s) } \\ \mathrm{mi} & \text { square mile(s) } \\ \mathrm{min} & \text { minute(s) } \\ \mathrm{mm} & \text { millimeter(s) } \\ \mathrm{mph} & \text { mile(s) per hour } \\ \mathrm{mrem} & \text { millirem } \\ \mathrm{psi} & \text { pound(s) per square inch } \\ \mathrm{rem} & \text { roentgen-equivalent man } \\ \mathrm{s} & \text { second(s) } \\ \mathrm{yr} & \text { year(s) }\end{array}$




\title{
RISK ASSESSMENT FOR THE OFF-SITE TRANSPORTATION \\ OF HIGH-LEVEL WASTE FOR THE U.S. DEPARTMENT \\ OF ENERGY WASTE MANAGEMENT PROGRAMMATIC \\ ENVIRONMENTAL IMPACT STATEMENT
}

by

F.A. Monette, B.M. Biwer, D.J. LePoire, and S.Y. Chen

\begin{abstract}
This report describes the human health risk assessment conducted for the transportation of high-level waste (HLW) in support of the U.S. Department of Energy Waste Management Programmatic Environmental Impact Statement (WM PEIS). The assessment considers risks to collective populations and individuals under both routine and accident transportation conditions for truck and rail shipment modes. The report discusses the scope of the HLW transportation assessment, describes the analytical methods used for the assessment, defines the alternatives considered in the WM PEIS, and details important assessment assumptions. Results are reported for five alternatives. In addition, to aid in the understanding and interpretation of the results, specific areas of uncertainty are described, with an emphasis on how the uncertainties may affect comparisons of the alternatives.
\end{abstract}

\section{INTRODUCTION}

This report presents a summary of the health risk assessment conducted for the transport of high-level waste (HLW) in support of the U.S. Department of Energy (DOE) Waste Management Programmatic Environmental Impact Statement (WM PEIS) (DOE 1996). Similar supporting technical reports have been prepared for the transportation assessments conducted for the WM PEIS alternatives for low-level, low-level mixed, and transuranic waste management (Monette et al. 1996a-c). The results of the assessment for HLW are summarized in Appendix E of the WM PEIS.

This report includes a discussion of the HLW inventory, characteristics, and alternatives evaluated in the WM PEIS and describes the analytical methods used for the transportation risk assessment (i.e., computer models), the important assessment assumptions, and the determination of potential routes for transportation. The results of the risk assessment are presented in detail for all HLW management alternatives. In addition, to aid in the understanding and interpretation of the 
results, specific areas of uncertainty are described, with an emphasis on how the uncertainties may affect comparisons of the alternatives. Finally, a discussion of measures that could be implemented to reduce potential impacts is provided.

Potential human health risks of both vehicle- and cargo-related transportation activities have been assessed for transportation crew members and members of the public. "Vehicle-related" risks result from the nature of transportation itself, independent of the radioactive characteristics of the cargo. For instance, increased levels of pollution from vehicular exhaust emissions may affect human health. Similarly, accidents during transportation may cause injuries and fatalities from physical trauma. On the other hand, "cargo-related" risk generally refers to additional risks that are attributable to characteristics of the shipment cargo.

The cargo-related impacts on human health during transportation of HLW are caused by exposure to ionizing radiation. Exposures to radiation occur under both routine (i.e., incident-free) transportation and accident conditions. During routine operations, humans can be exposed to the low-level radiation field of a loaded shipment. The external radiation field must be below limits specified in federal regulations for all shipments of radioactive material. During transportation accidents, human exposures may occur via multiple environmental pathways following the release and dispersal of radioactive material (e.g., external exposure to contaminated ground, inhalation of contaminated air, or the ingestion of contaminated food). Details of the methods used to assess the health risks posed by exposure to radiation are provided later in this report.

Note that throughout this report the methods and assumptions used in the transportation risk assessment were selected to ensure meaningful comparisons among programmatic-level alternatives. Therefore, this assessment uses a number of generic assumptions appropriate to the programmatic nature of the WM PEIS; for instance, because a detailed consideration of every possible waste shipment is impractical, representative physical and radiological characteristics have been determined for HLW for each generating DOE site. Similarly, routes for transportation have been selected to be consistent with current practice and applicable regulations but may not be the actual routes that would be used in the future.

Finally, care must be exercised when comparing the results of the WM PEIS HLW transportation risk assessment with those from previous transportation assessments. Extensive studies of transportation risk have been conducted previously for specific federal actions, some of which involve various degrees of HLW transportation (U.S. Nuclear Regulatory Commission [NRC] 1977a; DOE 1986, 1990a). Although some of the WM PEIS alternatives may be similar to those analyzed previously, differences may exist in the results of transportation risk assessments for a number of reasons. In general, the previous studies did not consider the range of programmatic alternatives currently being considered in the WM PEIS. As such, the previous studies used assumptions and parameters specific to the actions being considered, which are not necessarily appropriate for the purposes of the WM PEIS. In addition, revised radiation health risk conversion 
factors have been recently recommended by the International Commission on Radiological Protection (ICRP 1991), and data on the projected waste inventory and on characterization of wastes have been revised and updated. The results of the WM PEIS are not intended to replace the results of transportation risk assessments for ongoing or planned actions. 


\section{SCOPE OF ASSESSMENT}

The scope of the radiological risk assessment for HLW transport is presented in this section. Included are HLW inventories and characteristics, HLW management alternatives, transportationrelated activities, potential vehicle- and cargo-related impacts, receptors, and modes of transportation.

\subsection{BACKGROUND}

To support the WM PEIS analysis of HLW alternatives, a detailed report was prepared by Folga et al. (1996) describing the HLW inventory and characteristics at each DOE site. The report also describes the status, proposed schedules, important assumptions, and uncertainties associated with HLW treatment activities at each site. The report by Folga et al. (1996) is the primary source of information for the transportation assessment.

High-level waste was generated from the chemical reprocessing of spent nuclear fuel (SNF) and weapons production targets to recover special nuclear materials, primarily plutonium and enriched uranium, at four sites - the Hanford Site (Hanford), Idaho National Engineering Laboratory (INEL), Savannah River Site (SRS), and the West Valley Demonstration Project (WVDP). In 1992, DOE decided to phase out reprocessing in support of national defense activities. Additional HLW may be generated during environmental restoration activities. That HLW would require immobilization prior to final disposition.

The DOE now stores HLW in large tanks at the four sites where it was chemically reprocessed. Because the current forms of HLW (liquid or calcine) are generally not suitable for transportation, interim storage, or final disposal, plans call for all HLW to be immobilized in borosilicate glass at the site where it was produced (Folga et al. 1996). The immobilized material is generally a nondispersible, robust waste form that is formed in cylindrical stainless steel canisters approximately $300 \mathrm{~cm}$ (118 in.) high and $61 \mathrm{~cm}$ (24 in.) in diameter (Folga et al. 1996).

Under the Nuclear Waste Policy Act, as amended, the current DOE HLW program is directed at disposing treated (i.e., immobilized) $\mathrm{HLW}$ in a national geologic repository. Canisters of immobilized HLW would be stored on-site on an interim basis following production until a national geologic repository became available. Canisters would then be transported by either truck or rail to the repository in specially designed casks for permanent disposal. Historically, no shipments of immobilized HLW have taken place in the United States. 


\subsection{HIGH-LEVEL WASTE INVENTORY AND CHARACTERISTICS}

The risks from transporting HLW depend on the physical waste form, the number of vitrified HLW canisters produced, and the amount of radioactivity (curies) in each canister. The projected number of canisters is used to calculate the number of shipments necessary to transport HLW to storage or disposal facilities. The quantity of radioactivity in each canister is used to calculate the impacts of severe accidents that involve the possible release of radioactive material to the environment. Estimates of the projected physical waste forms, number of canisters, and the average radioactivity per canister for each HLW site are provided in Folga et al. (1996). A brief summary of the HLW inventory at each site is provided below.

\subsubsection{Hanford Site}

At the end of 1994, approximately $238,900 \mathrm{~m}^{3}$ of liquid HLW was stored at Hanford. This volume represents approximately $63 \%$ of the total DOE HLW inventory. The existing liquid HLW waste at Hanford is a result of nuclear fuel reprocessing operations carried out since 1943. The liquid HLW waste is currently stored in 177 underground storage tanks built between 1943 and 1986. Much of this waste is poorly characterized, and large uncertainties exist regarding the number of canisters of vitrified waste that will be produced. These uncertainties relate to the performance of various treatment and separation processes required to produce the vitrified waste. For purposes of the WM PEIS, it is assumed that vitrification of all the liquid HLW at Hanford will produce sufficient immobilized waste to fill approximately 15,000 canisters that will require eventual transportation to a national geologic repository (see Table 2.1) (Folga 1996). The estimated radionuclide content of the Hanford canisters is listed in Table 2.2. Construction of the HLW treatment facility is to begin in 2002, and facility operations are to begin in December 2009; vitrification is expected to be completed by December 2028.

\subsubsection{Savannah River Site}

Approximately $126,300 \mathrm{~m}^{3}$ of liquid HLW currently stored in underground carbon steel tanks is to be vitrified at the Defense Waste Processing Facility (DWPF) at SRS. The HLW is to be vitrified in borosilicate glass, which will be cast into stainless steel canisters. The DWPF began hot operations in 1996, and vitrified HLW canister production is expected to be completed in 2020. A total of 4,572 canisters are projected to be produced (Table 2.1). The estimated radionuclide content of each canister is provided in Table 2.2. 
TABLE 2.1 Projected Number of Canisters of HLW Produced at Each Site

\begin{tabular}{lr}
\hline Location & $\begin{array}{r}\text { Projected Number } \\
\text { of HLW Canisters }\end{array}$ \\
\hline Hanford & 15,000 \\
SRS & 4,572 \\
INEL & 1,700 \\
WVDP & 340 \\
\hline
\end{tabular}

Source: Folga et al. (1996).

\subsubsection{Idaho National Engineering Laboratory}

INEL has been generating liquid HLW from reprocessing activities since 1952. Because of space limitations and safety concerns, the majority of the HLW has been converted to a calcine waste, which is a granular, solid waste form. The calcine is not considered an adequate final waste form because of potential leaching of radionuclides upon contact with water. Some of the liquid HLW remains in underground tanks, and additional liquid HLW from decontamination efforts is also in storage (Folga 1996). Over time, this remaining liquid HLW will also be converted to calcine. It has been assumed that the calcine will be treated to yield a vitrified glass form (Folga et al. 1996). It has also been assumed that the INEL immobilization facility will begin operations in 2015 and complete immobilization in 2035 (Folga et al. 1996). An estimated total of 1,700 canisters of immobilized HLW are projected to be produced at INEL (Table 2.1). The estimated radionuclide content of each INEL canister is provided in Table 2.2.

\subsubsection{West Valley Demonstration Project}

In 1994 , approximately $2,180 \mathrm{~m}^{3}$ of liquid HLW was stored in two underground tanks at WVDP. The HLW stored at WVDP will be vitrified in borosilicate glass and cast into stainless steel canisters. The vitrification facility began hot operations in 1996 and is scheduled to complete vitrification in 1998. A total of 340 canisters of vitrified waste are projected to be produced (Table 2.1). The estimated radionuclide content of each canister is provided in Table 2.2. 
TABLE 2.2 Estimated Major Radionuclide Content per HLW Canister (Ci/canister)

\begin{tabular}{|c|c|c|c|c|}
\hline Radionuclide & Hanford & INEL & SRS & WVDP \\
\hline $\mathrm{Fe}-55$ & $1.80 \mathrm{E}+01$ & - & - & $2.76 \mathrm{E}+00$ \\
\hline Co-60 & $1.50 \mathrm{E}+00$ & - & $1.70 \mathrm{E}+02$ & $3.03 E+00$ \\
\hline $\mathrm{Ni}-59$ & $1.09 \mathrm{E}-01$ & 一 & $2.40 \mathrm{E}-02$ & $4.16 \mathrm{E}-01$ \\
\hline $\mathrm{Ni}-63$ & $1.21 \mathrm{E}+01$ & - & $2.98 \mathrm{E}+00$ & $3.02 E+01$ \\
\hline Se-79 & $3.15 \mathrm{E}-03$ & 一 & $1.70 \mathrm{E}-01$ & $1.38 \mathrm{E}-02$ \\
\hline $\mathrm{Rb}-87$ & - & - & $8.72 E-07$ & - \\
\hline Sr-89 & $5.35 \mathrm{E}-13$ & 一 & $4.27 \mathrm{E}-05$ & - \\
\hline Sr-90 & $2.98 \mathrm{E}+04$ & $2.09 \mathrm{E}+03$ & $4.68 \mathrm{E}+04$ & $2.63 E+04$ \\
\hline$Y-90$ & $2.98 \mathrm{E}+04$ & $2.09 \mathrm{E}+03$ & $4.79 E+04$ & $2.63 E+04$ \\
\hline Y-91 & $1.38 \mathrm{E}-10$ & 一 & $7.57 \mathrm{E}-04$ & - \\
\hline Zr-93 & $1.05 \mathrm{E}+00$ & 一 & $1.12 \mathrm{E}+00$ & $1.07 \mathrm{E}+00$ \\
\hline $\mathrm{Zr}-95$ & $2.92 \mathrm{E}-09$ & 一 & $1.00 \mathrm{E}-02$ & - \\
\hline $\mathrm{Nb}-93 \mathrm{~m}$ & $6.16 \mathrm{E}-01$ & - & 一 & $7.15 \mathrm{E}-01$ \\
\hline $\mathrm{Nb}-94$ & 一 & 一 & $9.65 \mathrm{E}-05$ & - \\
\hline $\mathrm{Nb}-95$ & $6.73 \mathrm{E}-09$ & - & $2.12 E-02$ & - \\
\hline $\mathrm{Nb}-95 \mathrm{~m}$ & 一 & 一 & $1.25 \mathrm{E}-04$ & - \\
\hline Tc-99 & $7.51 E+00$ & 一 & $3.08 \mathrm{E}+00$ & $4.28 \mathrm{E}-01$ \\
\hline $\mathrm{Ru}-103$ & $3.37 \mathrm{E}-18$ & - & $1.68 \mathrm{E}-08$ & - \\
\hline Ru-106 & $4.18 \mathrm{E}+01$ & $2.47 \mathrm{E}-15$ & $2.25 \mathrm{E}+03$ & $5.54 \mathrm{E}-02$ \\
\hline Rh-103m & $3.04 \mathrm{E}-18$ & - & $1.64 \mathrm{E}-08$ & - \\
\hline Rh-106 & $4.18 \mathrm{E}+01$ & $2.47 \mathrm{E}-15$ & $2.26 \mathrm{E}+03$ & $5.54 \mathrm{E}-02$ \\
\hline Pd-107 & $3.02 \mathrm{E}-02$ & - & $1.47 \mathrm{E}-02$ & $4.33 \mathrm{E}-02$ \\
\hline $\mathrm{Ag}-110 \mathrm{~m}$ & $2.22 \mathrm{E}-03$ & - & $1.26 \mathrm{E}-01$ & - \\
\hline $\mathrm{Cd}-113 \mathrm{~m}$ & $8.53 \mathrm{E}+00$ & - & - & $8.34 \mathrm{E}+00$ \\
\hline $\mathrm{Cd}-115 \mathrm{~m}$ & $3.20 \mathrm{E}-18$ & - & $1.21 \mathrm{E}-09$ & - \\
\hline In $-113 m$ & $1.01 \mathrm{E}-07$ & 一 & 一 & - \\
\hline Sn-113 & $1.01 \mathrm{E}-07$ & 一 & 一 & 一 \\
\hline Sn-119m & $6.80 \mathrm{E}-03$ & - & - & - \\
\hline $\mathrm{Sn}-121 \mathrm{~m}$ & $7.76 \mathrm{E}-02$ & - & $7.90 \mathrm{E}-02$ & $6.86 \mathrm{E}-02$ \\
\hline Sn-123 & $3.65 \mathrm{E}-05$ & - & $2.55 \mathrm{E}-01$ & - \\
\hline Sn-126 & $3.65 \mathrm{E}-01$ & - & $4.42 \mathrm{E}-01$ & $4.09 \mathrm{E}-01$ \\
\hline Sb-124 & $1.15 \mathrm{E}-14$ & 一 & $7.12 \mathrm{E}-08$ & - \\
\hline Sb-125 & $2.54 \mathrm{E}+02$ & - & $8.50 \mathrm{E}+02$ & $2.86 \mathrm{E}+01$ \\
\hline Sb-126 & $5.10 \mathrm{E}-02$ & 一 & $6.16 \mathrm{E}-02$ & $5.74 \mathrm{E}-02$ \\
\hline $\mathrm{Sb}-126 \mathrm{~m}$ & $3.65 \mathrm{E}-01$ & - & $4.42 \mathrm{E}-01$ & $4.09 \mathrm{E}-01$ \\
\hline
\end{tabular}


TABLE 2.2 (Cont.)

\begin{tabular}{|c|c|c|c|c|}
\hline Radionuclide & Hanford & INEL & SRS & WVDP \\
\hline $\mathrm{Te}-125 \mathrm{~m}$ & $6.20 \mathrm{E}+01$ & - & - & $7.00 \mathrm{E}+00$ \\
\hline $\mathrm{Te}-126 \mathrm{~m}$ & - & - & $2.76 \mathrm{E}+02$ & - \\
\hline $\mathrm{Te}-127$ & $6.55 E-06$ & - & $1.20 \mathrm{E}-01$ & - \\
\hline $\mathrm{Te}-127 \mathrm{~m}$ & $6.66 \mathrm{E}-06$ & - & $1.23 \mathrm{E}-01$ & - \\
\hline I-129 & $1.29 \mathrm{E}-05$ & - & - & - \\
\hline Cs-134 & $9.31 \mathrm{E}+01$ & $3.97 \mathrm{E}-06$ & $3.37 \mathrm{E}+02$ & $2.03 E+01$ \\
\hline Cs-135 & $2.02 \mathrm{E}-01$ & - & $9.94 \mathrm{E}-02$ & $6.34 \mathrm{E}-01$ \\
\hline Cs-137 & $3.61 E+04$ & $2.49 \mathrm{E}+03$ & $4.34 \mathrm{E}+04$ & $2.83 \mathrm{E}+04$ \\
\hline $\mathrm{Ba}-137 \mathrm{~m}$ & $3.40 \mathrm{E}+04$ & $2.36 \mathrm{E}+03$ & $4.16 \mathrm{E}+04$ & $2.68 \mathrm{E}+04$ \\
\hline Ce-142 & - & $\dot{-}$ & $9.61 \mathrm{E}-06$ & - \\
\hline $\mathrm{Ce}-144$ & $8.00 \mathrm{E}+01$ & $1.45 \mathrm{E}-18$ & $9.87 \mathrm{E}+03$ & $2.56 \mathrm{E}-03$ \\
\hline Pr-144 & $8.00 \mathrm{E}+01$ & $1.45 \mathrm{E}-18$ & $9.87 \mathrm{E}+03$ & $2.56 \mathrm{E}-03$ \\
\hline $\operatorname{Pr}-144 m$ & $9.60 \mathrm{E}-01$ & - & $1.19 \mathrm{E}+02$ & 一 \\
\hline Nd-144 & - & - & $4.86 \mathrm{E}-10$ & - \\
\hline $\mathrm{Pm}-146$ & - & - & - & $4.26 \mathrm{E}-02$ \\
\hline $\mathrm{Pm}-147$ & $5.21 \mathrm{E}+03$ & $1.78 \mathrm{E}-04$ & $2.42 E+04$ & $3.45 \mathrm{E}+02$ \\
\hline Sm-147 & - & - & $2.00 \mathrm{E}-06$ & - \\
\hline Sm-151 & $6.98 \mathrm{E}+02$ & - & $2.48 \mathrm{E}+02$ & $3.31 \mathrm{E}+02$ \\
\hline $\mathrm{Eu}-152$ & $1.40 \mathrm{E}+00$ & - & $3.69 \mathrm{E}+00$ & $1.43 \mathrm{E}+00$ \\
\hline Eu-154 & $1.45 E+02$ & $6.61 \mathrm{E}-01$ & $6.20 \mathrm{E}+02$ & $3.75 E+02$ \\
\hline $\mathrm{Eu}-155$ & $1.37 \mathrm{E}+02$ & 一 & $4.75 E+02$ & $9.37 \mathrm{E}+01$ \\
\hline Gd-153 & $1.35 \mathrm{E}-05$ & - & 一 & 一 \\
\hline $\mathrm{Tb}-160$ & $9.49 \mathrm{E}-13$ & - & $1.12 \mathrm{E}-06$ & 一 \\
\hline Tl-207 & - & - & - & $3.22 \mathrm{E}-02$ \\
\hline Tl-208 & - & - & $1.13 \mathrm{E}-03$ & $1.27 \mathrm{E}-02$ \\
\hline $\mathrm{Pb}-209$ & - & - & - & $8.25 \mathrm{E}-04$ \\
\hline $\mathrm{Pb}-211$ & - & - & - & $3.23 \mathrm{E}-02$ \\
\hline $\mathrm{Pb}-212$ & - & - & - & $3.53 \mathrm{E}-02$ \\
\hline $\mathrm{Bi}-211$ & - & - & - & $3.23 \mathrm{E}-02$ \\
\hline $\mathrm{Bi}-212$ & - & - & 一 & $3.53 \mathrm{E}-02$ \\
\hline $\mathrm{Bi}-213$ & - & - & - & $8.25 \mathrm{E}-04$ \\
\hline Po-212 & - & - & - & $2.26 \mathrm{E}-02$ \\
\hline Po-213 & - & 一 & - & $7.86 \mathrm{E}-04$ \\
\hline Po-215 & - & - & - & $3.23 E-02$ \\
\hline Po-216 & - & - & - & $3.53 \mathrm{E}-02$ \\
\hline At-217 & - & - & - & $8.25 E-04$ \\
\hline
\end{tabular}


TABLE 2.2 (Cont.)

\begin{tabular}{|c|c|c|c|c|}
\hline Radionuclide & Hanford & INEL & SRS & WVDP \\
\hline$R n-219$ & - & - & - & $3.23 E-02$ \\
\hline$R n-220$ & 一 & - & 一 & $3.53 E-02$ \\
\hline Fr-221 & - & - & - & $8.25 \mathrm{E}-04$ \\
\hline Fr-223 & - & 一 & - & $4.32 \mathrm{E}-04$ \\
\hline $\mathrm{Ra}-223$ & - & - & 一 & $3.23 E-02$ \\
\hline $\mathrm{Ra}-224$ & - & - & - & $3.53 \mathrm{E}-02$ \\
\hline $\mathrm{Ra}-225$ & - & - & 一 & $8.25 \mathrm{E}-04$ \\
\hline $\mathrm{Ra}-228$ & - & 一 & - & $5.97 \mathrm{E}-03$ \\
\hline Ac-225 & - & - & - & $8.25 \mathrm{E}-04$ \\
\hline Ac- 227 & 一 & 一 & - & $3.23 E-04$ \\
\hline Ac- 228 & - & - & - & $5.97 \mathrm{E}-03$ \\
\hline Th-227 & 一 & - & - & $3.18 \mathrm{E}-02$ \\
\hline Th-228 & 一 & - & - & $3.53 \mathrm{E}-02$ \\
\hline Th-229 & - & - & - & $9.25 \mathrm{E}-04$ \\
\hline Th-230 & - & - & 一 & $2.36 \mathrm{E}-04$ \\
\hline Th-231 & - & 一 & 一 & $3.54 \mathrm{E}-04$ \\
\hline Th-232 & - & - & - & $6.45 \mathrm{E}-03$ \\
\hline Th-234 & - & - & 一 & $3.14 \mathrm{E}-03$ \\
\hline $\mathrm{Pa}-231$ & 一 & - & 一 & $5.97 \mathrm{E}-02$ \\
\hline $\mathrm{Pa}-233$ & 一 & - & - & $9.18 \mathrm{E}-02$ \\
\hline $\mathrm{Pa}-234 \mathrm{~m}$ & 一 & - & 一 & $3.14 \mathrm{E}-03$ \\
\hline $\mathrm{U}-232$ & - & - & $1.34 \mathrm{E}-02$ & $2.72 \mathrm{E}-02$ \\
\hline $\mathrm{U}-233$ & - & - & $1.58 \mathrm{E}-06$ & $3.55 \mathrm{E}-02$ \\
\hline $\mathrm{U}-234$ & $4.57 \mathrm{E}-03$ & - & $3.43 \mathrm{E}-02$ & $1.65 \mathrm{E}-02$ \\
\hline U-235 & $1.91 \mathrm{E}-04$ & - & $1.57 \mathrm{E}-04$ & $3.54 \mathrm{E}-04$ \\
\hline U-236 & $4.21 \mathrm{E}-04$ & - & $1.13 \mathrm{E}-03$ & $1.10 \mathrm{E}-03$ \\
\hline U-237 & - & - & - & - \\
\hline U-238 & $3.51 \mathrm{E}-03$ & - & $1.05 \mathrm{E}-02$ & $3.14 \mathrm{E}-03$ \\
\hline Np-236 & - & - & - & $3.72 \mathrm{E}-02$ \\
\hline Np-237 & $1.56 \mathrm{E}-01$ & - & $8.90 \mathrm{E}-03$ & $9.18 \mathrm{E}-02$ \\
\hline Np-239 & 一 & - & 一 & $1.36 \mathrm{E}+00$ \\
\hline $\mathrm{Pu}-236$ & - & - & $1.22 \mathrm{E}-01$ & $3.30 \mathrm{E}-03$ \\
\hline $\mathrm{Pu}-238$ & $4.43 \mathrm{E}-01$ & - & $1.48 \mathrm{E}+03$ & $3.26 \mathrm{E}+01$ \\
\hline $\mathrm{Pu}-239$ & $1.17 \mathrm{E}+00$ & - & $1.29 \mathrm{E}+01$ & $6.39 \mathrm{E}+00$ \\
\hline $\mathrm{Pu}-240$ & $3.93 \mathrm{E}-01$ & - & $8.68 \mathrm{E}+00$ & $4.68 \mathrm{E}+00$ \\
\hline $\mathrm{Pu}-241$ & $1.26 \mathrm{E}+01$ & - & $1.67 \mathrm{E}+03$ & $3.17 \mathrm{E}+02$ \\
\hline
\end{tabular}


TABLE 2.2 (Cont.)

\begin{tabular}{lcccc}
\hline Radionuclide & Hanford & INEL & SRS & WVDP \\
\hline Pu-242 & $7.61 \mathrm{E}-05$ & - & $1.22 \mathrm{E}-02$ & $6.37 \mathrm{E}-03$ \\
$\mathrm{Am}-241$ & $2.84 \mathrm{E}+02$ & - & $1.10 \mathrm{E}+01$ & $2.10 \mathrm{E}+02$ \\
$\mathrm{Am}-242$ & $2.21 \mathrm{E}-01$ & - & $1.44 \mathrm{E}-02$ & $1.16 \mathrm{E}+00$ \\
$\mathrm{Am}-242 \mathrm{~m}$ & $3.79 \mathrm{E}-02$ & - & $1.45 \mathrm{E}-02$ & $1.17 \mathrm{E}+00$ \\
$\mathrm{Am}-243$ & - & - & $5.79 \mathrm{E}-03$ & $1.36 \mathrm{E}+00$ \\
$\mathrm{Cm}-242$ & $1.82 \mathrm{E}-01$ & - & $3.50 \mathrm{E}-02$ & $9.63 \mathrm{E}-01$ \\
$\mathrm{Cm}-243$ & - & - & $5.56 \mathrm{E}-03$ & $5.27 \mathrm{E}-01$ \\
$\mathrm{Cm}-244$ & $5.03 \mathrm{E}+00$ & - & $1.08 \mathrm{E}+02$ & $3.00 \mathrm{E}+01$ \\
$\mathrm{Cm}-245$ & - & - & $6.72 \mathrm{E}-06$ & $3.46 \mathrm{E}-03$ \\
$\mathrm{Cm}-246$ & - & - & $5.34 \mathrm{E}-07$ & $3.93 \mathrm{E}-04$ \\
Total & $1.37 \mathrm{E}+05$ & $9.03 \mathrm{E}+03$ & $2.34 \mathrm{E}+05$ & $1.10 \mathrm{E}+05$ \\
\hline
\end{tabular}

a Radionuclide not present or at negligible concentration.

Source: Folga et al. (1996).

\subsection{HIGH-LEVEL WASTE ALTERNATIVES}

For purposes of the WM PEIS, DOE is considering a broad range of alternatives for the configuration of new or expanded waste management facilities and the potential consolidation of existing facilities. In general, the WM PEIS alternatives reflect decentralized, regionalized, and centralized approaches. The individual alternatives differ in the number, location, and types of facilities for treatment, storage, and disposal that are being considered.

The HLW alternatives consider the potential consolidation of immobilized HLW canisters for purposes of interim storage prior to shipment to a geologic repository. For instance, the HLW canisters could be stored at the four sites where they were produced and where the HLW was generated or treated, or the canisters could be consolidated at one or more storage sites. The anticipated decision making on the WM PEIS relative to HLW concerns whether and where to consolidate storage of HLW canisters prior to transport to a national geologic repository. For the purposes of assessing the impacts of transportation, the WM PEIS assumes the repository location to be at the candidate site of Yucca Mountain in Nevada, which is the only site currently authorized by legislation for investigation. The definitions of the alternatives are provided below and summarized in Table 2.3. 
TABLE 2.3 Summary of HLW Transportation Analyzed in the WM PEIS

\begin{tabular}{ll}
\hline Alternative & \multicolumn{1}{c}{ Description of Transportation Involved } \\
\hline No Action & $\begin{array}{l}\text { Immobilized HLW shipped directly from WVDP, } \\
\text { Hanford, and SRS. INEL stores own waste. }\end{array}$ \\
Decentralized & $\begin{array}{l}\text { Immobilized HLW shipped directly from WVDP, } \\
\text { Hanford, INEL, and SRS to repository when } \\
\text { available. }\end{array}$ \\
Regionalized 1 & $\begin{array}{l}\text { WVDP-immobilized HLW shipped to SRS for } \\
\text { interim storage. Hanford, SRS, INEL, and WVDP }\end{array}$ \\
Regionalized 2 & $\begin{array}{l}\text { HLW at SRS shipped to repository when available. } \\
\text { Shipped to Hanford for interim storage. }\end{array}$ \\
Centralized & $\begin{array}{l}\text { Shipment of WVDP, INEL, and some SRS HLW } \\
\text { canisters to Hanford for interim storage. Shipment } \\
\text { of all HLW canisters to repository when available. }\end{array}$ \\
\hline
\end{tabular}

Five HLW alternatives exist: (1) No Action, (2) Decentralized, (3) Regionalized 1, (4) Regionalized 2, and (5) Centralized. Each alternative consists of two cases: Case 1 assumes that the repository begins accepting waste in January of 2015, and Case 2 assumes that the repository begins accepting waste at some later date. Except for the Centralized Alternative, the overall transportation risks are the same for Case 1 and Case 2 in each alternative; the difference lies only in the starting date for shipments to the repository. Therefore, the transportation risks were calculated for six cases: one each for the No Action, Decentralized, Regionalized 1, and Regionalized 2 Alternatives; and two cases for the Centralized Alternative.

The alternatives are defined in the WM PEIS (DOE 1996) and are summarized as follows:

- No Action. Store HLW canisters on an interim basis at Hanford, SRS, and WVDP in existing and approved interim storage facilities until the acceptance of HLW canisters at a geologic repository. Store HLW at INEL in calcine bin sets as calcine or in tank farms as liquid HLW.

- Decentralized. Provide adequate interim storage capacity for HLW canisters at each of the four sites that would produce HLW canisters until the acceptance of HLW canisters at a geologic repository. HLW at INEL is vitrified and placed in HLW canisters. 
- Regionalized 1. Transport HLW canisters from the WVDP to the SRS and provide adequate interim storage capacity for HLW canisters at Hanford, SRS, and INEL until the acceptance of HLW canisters at a geologic repository.

- Regionalized 2. Transport the HLW canisters from the WVDP to Hanford and provide adequate interim storage capacity for HLW canisters at Hanford, SRS, and INEL until the acceptance of HLW canisters at a geologic repository.

- Centralized. Transport the HLW canisters from the WVDP, INEL, and SRS to Hanford and provide adequate interim storage capacity for HLW canisters at Hanford until the acceptance of HLW canisters at a geologic repository. Case 1 assumes that the repository opens on time in the year 2015. Case 2 assumes that the repository opens later and that all HLW is stored temporarily at Hanford.

\subsection{DESCRIPTION OF TRANSPORTATION ACTIVITIES}

The transportation risk assessment is limited to estimating the human health risks incurred during the actual transportation of immobilized HLW by truck or rail. Transportation of liquid HLW or intermediate waste forms by pipeline or other means is not considered within the scope of the transportation assessment. The risks to workers or to the public during the loading, unloading, and handling of waste before or after shipment are considered as part of normal operations of the facility and are not included in the transportation assessment. Similarly, the transportation risk assessment does not address how increased transportation levels may possibly impact on local traffic flow, noise levels, logistics, or infrastructure.

\subsection{CARGO-RELATED IMPACTS (RADIOLOGICAL)}

For radioactive materials, the cargo-related impacts on human health during HLW transportation are caused by exposure to ionizing radiation. For all cases, radiological risks (that is, risks that result from the radioactive nature of the HLW) are assessed both for routine (normal) transportation and for accident conditions. The radiological risk associated with routine transportation results from the potential exposure of people to low levels of external radiation in the vicinity of a loaded shipment. The radiological risk from transportation-related accidents lies in the potential release and dispersal of radioactive material into the environment during an accident and the subsequent exposure of people through multiple exposure pathways (i.e., exposure to contaminated ground or air or the ingestion of contaminated food). 
All radiologically related impacts are calculated in terms of dose and associated health effects in the exposed populations. The dose of radiation calculated is the total effective dose equivalent as specified in Title 10 of the Code of Federal Regulations (10 CFR Part 20), which is the sum of the effective dose equivalent from exposure to external radiation and the 50-year committed effective dose equivalent (ICRP 1977) from exposure to internal radiation. Doses of radiation are calculated in units of roentgen-equivalent man (rem) for individuals and in units of person-rem for collective populations.

The potential exposures to the general population from transport of radioactive materials, whether during routine operations or from postulated accidents, are usually at a low dose, such that the primary adverse health effect is the potential induction of latent cancers (that is, cancers that occur after a latency period of several years from the time of exposure). The correlation of radiation dose and human health effects for low doses has been traditionally based on what is termed the "linear/no-threshold hypothesis," which has been described by various international authorities on protection against radiation. This hypothesis implies, in part, that even small doses of radiation cause some risk of inducing cancer and that doubling the radiation dose would mean doubling the expected numbers of cancers. The types of cancer induced by radiation are similar to "naturally occurring" cancers and can be expressed later in the lifetimes of the exposed individuals.

Based upon the analyses conducted for this report, HLW transportation-related operations are not expected to cause acute (short-term) radiation-induced fatalities or to produce immediately observable effects in exposed individuals. Acute radiation-induced fatalities occur at doses well in excess of 100 rem (ICRP 1991), which generally would not occur for a wide range of transportation activities, including routine operations and accident conditions. ${ }^{1}$ For all severe accident scenarios analyzed, other short-term effects such as temporary sterility and changes in blood chemistry are not expected.

In this report, the radiological impacts are expressed as health risks in terms of the number of estimated latent cancer fatalities, the incidence of cancer, and the genetic effects in exposed populations for each alternative. The health risk conversion factors (expected latent health effects per dose absorbed) were derived from ICRP publication 60 (ICRP 1991).

\subsection{VEHICLE-RELATED IMPACTS (NONRADIOLOGICAL)}

In addition to the radiological risks posed by transportation-related activities, risks are also assessed for vehicle-related causes for the same routes. These risks are independent of the radioactive nature of the cargo and would be incurred for similar shipments of any commodity. The

1 In general, individual acute whole-body doses in the range of 300-500 rem are expected to cause fatality in $50 \%$ of the exposed individuals within 30-60 days (ICRP 1991). 
vehicle-related risks are assessed for both routine and accident conditions. Vehicle-related risks during routine transportation are caused by potential exposure to increased vehicular exhaust emissions. The routine risks are primarily associated with travel in urban environments. The vehicle-related accident risk refers to the potential for transportation-related accidents that result in fatalities due to physical trauma and not related to the cargo in the shipment. State-specific rates for transportation-related fatalities are used in the assessment. Vehicle-related risks are presented in terms of estimated fatalities for each alternative.

\subsection{TRANSPORTATION MODES}

Although HLW could be transported by a variety of modes, all shipments have been assumed to take place by either truck or rail. For each case, risks have been calculated separately for all truck and all rail options, although the actual shipping campaigns for a selected alternative may involve a combination of the two modes. Rail shipments are assumed to take place by regular freight train service-the use of special or dedicated rail service was not considered. Shipments by barge, although feasible for some sites, have not been explicitly considered because this mode of transportation is somewhat limited and has not been established as a major programmatic option for the WM PEIS assessment. Similarly, shipments by aircraft and other modes are not considered.

\subsection{RECEPTORS}

In this report, transportation-related risks are calculated and presented separately for workers and members of the general public. The workers considered are truck and rail crew members involved in transporting HLW. The general public includes all persons who could be exposed to a shipment while it is moving or stopped en route. Potential risks are estimated for the collective populations of exposed people, as well as for maximally exposed individuals (MEIs). The collective population risk is a measure of the radiological risk posed to society as a whole by the alternative being considered. As such, the collective population risk is used as the primary means of comparing various alternatives. 


\section{PACKAGING REGULATIONS AND ASSUMPTIONS}

Regulations that govern the transport of radioactive materials are designed to protect the public from the potential loss or dispersal of radioactive materials, as well as from routine doses of radiation during transit. The primary regulatory approach to ensure safety is through the specification of standards for the packaging of radioactive materials.

Because packaging represents the primary barrier between the radioactive material being transported and exposure of the public and the environment to radiation, requirements for packaging are an important consideration for the transportation risk assessment. Regulatory packaging requirements are discussed in this section. In addition, the packaging assumptions for HLW are described.

\subsection{PACKAGING REGULATIONS}

Although several federal and state organizations are involved in regulating radioactive waste transport, primary regulatory responsibility resides with the U.S. Department of Transportation (DOT) and the NRC. In addition, DOE has formalized agreements with both NRC and DOT to delineate the responsibilities of their respective agencies. All transportation-related activities must take place in accordance with the applicable regulations of these agencies specified in 49 CFR Part 173 and 10 CFR Part 71.

Packaging for radioactive materials must be designed, constructed, and maintained to ensure that they will contain and shield their contents during normal transportation. For more highly radioactive material, such as $\mathrm{HLW}$, the packaging must be capable of containing and shielding their contents in severe accidents. The type of packaging used is determined by the total radioactive hazard presented by the material within the packaging. The basic types of packagings required by the applicable regulations are designated as Type A, Type B, or "strong and tight" (generally for lowspecific-activity material).

Type A packaging must withstand the conditions of normal transportation without the loss or dispersal of the radioactive contents. "Normal" transportation refers to all conditions of transportation except those that result from accidents or sabotage. Approval of Type A packaging is achieved by demonstrating that the packaging can withstand specified testing conditions that are intended to simulate normal transportation. Type A packaging, typically a 208-L (55-gal) drum or standard waste box, is commonly used to transport wastes having low levels of radioactivity. Type A packaging is routinely used in waste management for purposes of storage, transportation, and disposal. In general, the use of Type A packaging does not require special handling, packaging, or transportation equipment. 
In addition to meeting the standards for Type A packaging, Type B packaging must provide a high degree of assurance that, even in severe accidents, the integrity of the package will be maintained, with essentially no loss of the radioactive contents or serious impairment of the shielding capability. Type B packaging is required for the shipment of large quantities of radioactive material, including HLW, and must satisfy stringent testing criteria (specified in 10 CFR Part 71). The testing criteria were developed to simulate the conditions of severe hypothetical accidents, including impact, puncture, fire, and immersion in water, and are summarized in Table 3.1. The massive casks used for transporting highly radioactive spent nuclear fuel from nuclear power stations are the most widely recognized Type B packaging. The handling of Type B packaging generally requires the use of large-capacity cranes and mechanical lifting equipment. Many Type B packagings are transported on trailers specifically designed for the package being used.

\section{TABLE 3.1 Type B Packaging Test Conditions}

Test

Conditions

Free drop Drop through $30 \mathrm{ft}(9 \mathrm{~m})$ onto a flat, unyielding, horizontal surface, striking in a position expected to do the most damage.

Puncture Free drop $40 \mathrm{in}$. $(1 \mathrm{~m})$ in a position for which maximum damage is expected onto the upper end of a solid, vertical, cylindrical steel bar mounted on an essentially unyielding surface. Bar must be 6 in. $(15 \mathrm{~cm})$ in diameter, with the top horizontal and its edge rounded to $1 / 4$ in. $(6 \mathrm{~mm})$ in radius. Bar's long axis must be vertical and not less than 8 in. $(20 \mathrm{~cm})$.

Immersion Fissile material: the specimen must be immersed under a head of water of at least $3 \mathrm{ft}(1 \mathrm{~m})$ for a period of not less than $8 \mathrm{~h}$ and in the altitude for which maximum leakage is expected.

All packages: the specimen must be subjected to water pressure equivalent to immersion under a head of water of at least $50 \mathrm{ft}(15 \mathrm{~m})$ for a period of not less than $8 \mathrm{~h}$. For test purposes, an external pressure of water of $21 \mathrm{psi}$ gauge is considered to meet these conditions.

Thermal Exposure of the whole specimen for not less than 30 min to a heat flux not less than that of a radiation environment of $800^{\circ} \mathrm{C}\left(1,472^{\circ} \mathrm{F}\right)$ with an emissivity coefficient of at least 0.9 . Artificial cooling must not be applied after cessation of external heat input, and any combustion of materials of construction must be allowed to proceed until combustion terminates naturally.

Source: 10 CFR Part 71. 
External radiation allowed to escape from a package must be below specified limits that minimize the exposure of the handling personnel and the general public. High-level waste shipments will be handled only by the shipper and the receiver, an arrangement referred to as an "exclusiveuse" shipment. For this type of shipment, the dose rate for external radiation during normal transportation must be maintained below the following limits (49 CFR Part 173):

- Dose of $10 \mathrm{mrem} / \mathrm{h}$ at any point $2 \mathrm{~m}(6.6 \mathrm{ft})$ from the vertical planes projected by the outer lateral surfaces of the car or vehicle, and

- Dose of $2 \mathrm{mrem} / \mathrm{h}$ in any normally occupied position in the car or vehicle.

Additional restrictions apply to radiation levels on the surface of the package; however, these restrictions do not affect the transportation-related radiological risk assessment.

For the purposes of risk assessment, specifying the actual package that will be used is not necessary, because all packagings of a given type are designed to meet the same criteria for performance. For instance, all Type B casks would be expected to behave similarly under conditions of routine transportation and accidents because they are designed to the same performance criteria.

\subsection{PACKAGING ASSUMPTIONS}

Canisters of vitrified HLW will be shipped in Type B packages that meet the criteria specified above. For risk assessment purposes, initial designs for the defense high-level waste (DHLW) cask being prepared for shipment of SRS HLW were assumed to be representative of casks used by all four DOE HLW sites. The DHLW cask uses a solid-body concept; the cask body is designed to absorb energy during hypothetical accident and normal transport conditions; gamma shielding is provided by a depleted uranium liner contained within the cask body (Moore et al. 1983). The number of canisters to be transported in a cask differs between truck and rail modes because of weight limitations. The DHLW truck cask is designed to accept one HLW canister; rail capacity was assumed to be five canisters (DOE 1987a).

In the future, it is likely that DOE will develop a multiple-canister truck cask in order to minimize the number of shipments for major shipping campaigns. However, because a multiplecanister cask does not currently exist, impacts were calculated assuming that the single-canister DHLW cask will be used. If a multiple-canister truck cask is used in the future, risks will be significantly less than those presented in this analysis because the number of shipments will be fewer. 


\section{ANALYSIS OF TRUCK AND RAIL ROUTING}

The calculation of the transportation risk for an alternative depends, in part, on the characteristics of the transport routes between the origin and destination sites. Regulatory routing criteria and the methods used to determine representative truck and rail routes for the transportation risk assessment are described in this section.

\subsection{ROUTING REGULATIONS}

The public-highway routing regulations of DOT are prescribed in 49 CFR Part 177 (Docket HM-164). The objectives of the regulations are to reduce the impacts of transporting radioactive materials, to establish consistent and uniform requirements for route selection, and to identify the role of state and local governments in the routing of radioactive materials. The regulations attempt to reduce potential hazards by avoiding populous areas and by minimizing travel times. Further, the regulations require that the carrier of radioactive materials ensure that the vehicle is operated on routes that minimize radiological risks and that accident rates, transit times, population density and activity, time of day, and day of week are considered in determining risk.

A shipment of a "highway-route-controlled quantity" of radioactive materials is required by Docket HM-164 to use the interstate highway system except when moving from origin to interstate or from interstate to destination, when making necessary repair or rest stops, or when emergency conditions make continued use of the interstate unsafe or impossible. Carriers are required to use interstate circumferential or bypass routes, if available, to avoid populous areas. Other "preferred highways" may be designated by any state or Native American tribe to replace or supplement the interstate system. Under its authority to regulate the safety of interstate transportation, DOT can prohibit state and local bans and restrictions as "undue restraint of interstate commerce." State or local bans may be preempted if inconsistent with Docket HM-164.

Currently, no DOT railroad routing regulation specific to the transport of radioactive materials exists. Routes are generally fixed by the location of rail lines, and urban areas cannot be readily bypassed.

\subsection{REPRESENTATIVE TRANSPORTATION ROUTES}

Representative truck and rail routes were determined for the pairs of origin and destination sites specified by the alternative definitions. Route characteristics are summarized in Table 4.1 for both truck and rail modes. The routes were selected to be consistent with current routing practices 
TABLE 4.1 Route Summary Information for HLW Shipments Considered in the WM PEIS

\begin{tabular}{|c|c|c|c|c|}
\hline \multirow[b]{2}{*}{ Mode/Route } & \multirow{2}{*}{$\begin{array}{l}\text { Distance } \\
\text { (mi) }\end{array}$} & \multicolumn{3}{|c|}{ Percentage in Zone ${ }^{a}$} \\
\hline & & Rural & Suburban & Urban \\
\hline \multicolumn{5}{|l|}{ Truck $^{b}$} \\
\hline WVDP to Yucca Mountain & 2,407 & 83.9 & 14.1 & 2.0 \\
\hline WVDP to SRS & 883 & 70.3 & 28.5 & 1.2 \\
\hline WVDP to Hanford & 2,556 & 84.6 & 13.7 & 1.7 \\
\hline SRS to Hanford & 2,727 & 84.3 & 14.2 & 1.5 \\
\hline SRS to Yucca Mountain & 2,448 & 83.3 & 14.9 & 1.8 \\
\hline INEL to Yucca Mountain & 746 & 83.6 & 13.0 & 3.4 \\
\hline Hanford to Yucca Mountain & 1,162 & 86.9 & 10.5 & 2.5 \\
\hline \multicolumn{5}{|l|}{ Raill $^{\mathrm{c}}$} \\
\hline WVDP to Yucca Mountain & 2,540 & 78.0 & 18.0 & 4.0 \\
\hline WVDP to SRS & 1,217 & 62.8 & 32.4 & 4.9 \\
\hline WVDP to Hanford & 2,654 & 78.3 & 18.0 & 3.7 \\
\hline SRS to Hanford & 2,953 & 84.7 & 13.5 & 1.8 \\
\hline SRS to Yucca Mountain & 2,839 & 84.5 & 3.5 & 1.9 \\
\hline INEL to Yucca Mountain & 756 & 92.8 & 5.9 & 1.3 \\
\hline Hanford to Yucca Mountain & 1,302 & 93.0 & 5.9 & 1.1 \\
\hline
\end{tabular}

a Rural $=0-139$ persons $/ \mathrm{mi}^{2} ;$ suburban $=140-3,326 / \mathrm{mi}^{2}$; urban $=>3,326 / \mathrm{mi}^{2}$.

b Truck route information was generated using the HIGHWAY 3.1 computer code (Johnson et al. 1993a).

c Rail route information was generated using the INTERLINE 5.0 computer code (Johnson et al. 1993b).

and all applicable routing regulations and guidelines; however, because the routes were determined for the purposes of risk assessment, the routes do not necessarily represent the actual routes that would be used to transport HLW in the future. The DOE has not made route determinations for HLW at this time.

The representative truck and rail routes were determined by using the routing models HIGHWAY 3.1 (Johnson et al. 1993a) and INTERLINE 5.0 (Johnson et al. 1993b), respectively. For both truck and rail, the route characteristics that are most important to the radiological risk assessment include the total shipping distance between each origin- destination pair and the fractions 
of travel in rural, suburban, and urban zones of population density. The route selected determines the total potentially exposed population along a route and the expected frequency of transportationrelated accidents.

\subsubsection{HIGHWAY 3.1}

The HIGHWAY 3.1 computer program is used for predicting highway routes for transporting radioactive materials within the United States by truck. The HIGHWAY database is a computerized road atlas that currently describes approximately $386,243 \mathrm{~km}(240,000 \mathrm{mi})$ of roads. A complete description of the interstate highway system and of all U.S. highways is included in the database. In addition, most of the principal state highways and a number of local and community highways are also identified. The code is updated periodically to reflect current road conditions and has been benchmarked against reported mileages and observations of commercial trucking firms.

Routes are calculated within the model by minimizing the total impedance between the origin and the destination. The impedance is defined basically as a function of distance and driving time along a particular segment of highway. One of the special features of the HIGHWAY 3.1 model is its ability to calculate routes that maximize the use of interstate highways. This feature allows the user to predict routes for shipment of radioactive materials that conform to DOT transportation regulations, specifically Docket HM-164. The population densities along a route are derived from 1990 data from the U.S. Bureau of the Census. Rural, suburban, and urban areas are characterized according to the following breakdown: rural population densities range from 0 to 54 persons $/ \mathrm{km}^{2}$ $\left(0-139 / \mathrm{mi}^{2}\right)$; the suburban range is $55-1,284 / \mathrm{km}^{2}\left(140-3,326 / \mathrm{mi}^{2}\right)$; and urban is taken to mean all population densities greater than $1,284 / \mathrm{km}^{2}\left(3,326 / \mathrm{mi}^{2}\right)$.

\subsubsection{INTERLINE 5.0}

The INTERLINE 5.0 computer program is designed to simulate routing of the U.S. rail system. The INTERLINE database consists of 94 separate subnetworks and represents various competing rail companies in the United States. The database used by INTERLINE was originally based on data from the Federal Railroad Administration and reflected the U.S. railroad system in 1974. The database has since been expanded and modified over the past two decades. The code is updated periodically to reflect current track conditions and has been benchmarked against reported mileages and observations of commercial rail firms.

The INTERLINE 5.0 model uses a shortest-route algorithm that finds the path of minimum impedance within an individual subnetwork. A separate routine is used to find paths along the subnetworks. The routes chosen for this study used the standard assumptions in the INTERLINE model that simulate the process of selection that railroads would use to direct shipments of radioactive waste. For sites that do not have direct rail access, the rail siding nearest the site was used for routing purposes. The population densities along a route are derived from 1990 census data. 
Rural, suburban, and urban areas are characterized according to the following breakdown: rural population densities range from 0 to 54 persons $/ \mathrm{km}^{2}\left(0-139 / \mathrm{mi}^{2}\right)$, the suburban range for population density is $55-1,284 / \mathrm{km}^{2}\left(140-3,326 / \mathrm{mi}^{2}\right)$, and urban is taken to mean all population densities greater than $1,284 / \mathrm{km}^{2}\left(3,326 / \mathrm{mi}^{2}\right)$. 


\section{METHODS FOR CALCULATING TRANSPORTATION-RELATED RISKS}

The technical approach for conducting the transportation risk assessment was developed following a thorough and critical review of the literature and existing documentation in the National Environmental Policy Act for federal actions involving transportation of radioactive materials. Consideration was also given to recent DOE commitments arising from both litigation and public awareness. The approach selected uses several computer models and databases to determine the risks for each case.

The approach for the transportation risk assessment is summarized in Figure 5.1 and is discussed in detail in this section. For each case, risks are assessed for both routine transportation and accidents. For the routine assessment, risks are calculated for the collective populations of potentially exposed individuals, as well as for the MEIs. The accident assessment consists of two components: (1) an accident risk assessment, which considers the probabilities and consequences of a range of possible transportation-related accidents, including low-probability accidents that have high consequences, and high-probability accidents that have low consequences; and (2) an accident consequence assessment, which considers only the radiological consequences of the severe transportation-related accidents that are postulated to result in the largest releases of radioactive material.

The RADTRAN 4 computer code (Neuhauser and Kanipe 1993) is used for the routine and accident risk assessments to estimate the impacts to collective populations. RADTRAN 4 was developed by Sandia National Laboratories to calculate population risks associated with the transportation of radioactive materials by a variety of modes, including truck, rail, air, ship, and barge. The code has been extensively reviewed, updated, and used for transportation risk assessments since it was issued in the late 1970s.

The RADTRAN 4 calculations of population risk take into account both the consequences and the probabilities of potential exposures. The collective population risk is a measure of the total radiological risk posed to society as a whole by the alternative being considered. As such, the collective population risks are used as the primary means of comparing the various alternatives.

As a complement to the RADTRAN calculations, the RISKIND computer code (Yuan et al. 1993) is used to estimate scenario-specific doses to MEIs for both routine operation and accident conditions, and to estimate population impacts for the accident consequence assessment. The RISKIND computer code was developed for the DOE Office of Civilian Radioactive Waste Management specifically to analyze radiological consequences to individuals and population subgroups associated with the transportation of spent nuclear fuel. Minor modifications to the code were made for WM PEIS applications to accommodate shipments of all types of radioactive waste. 

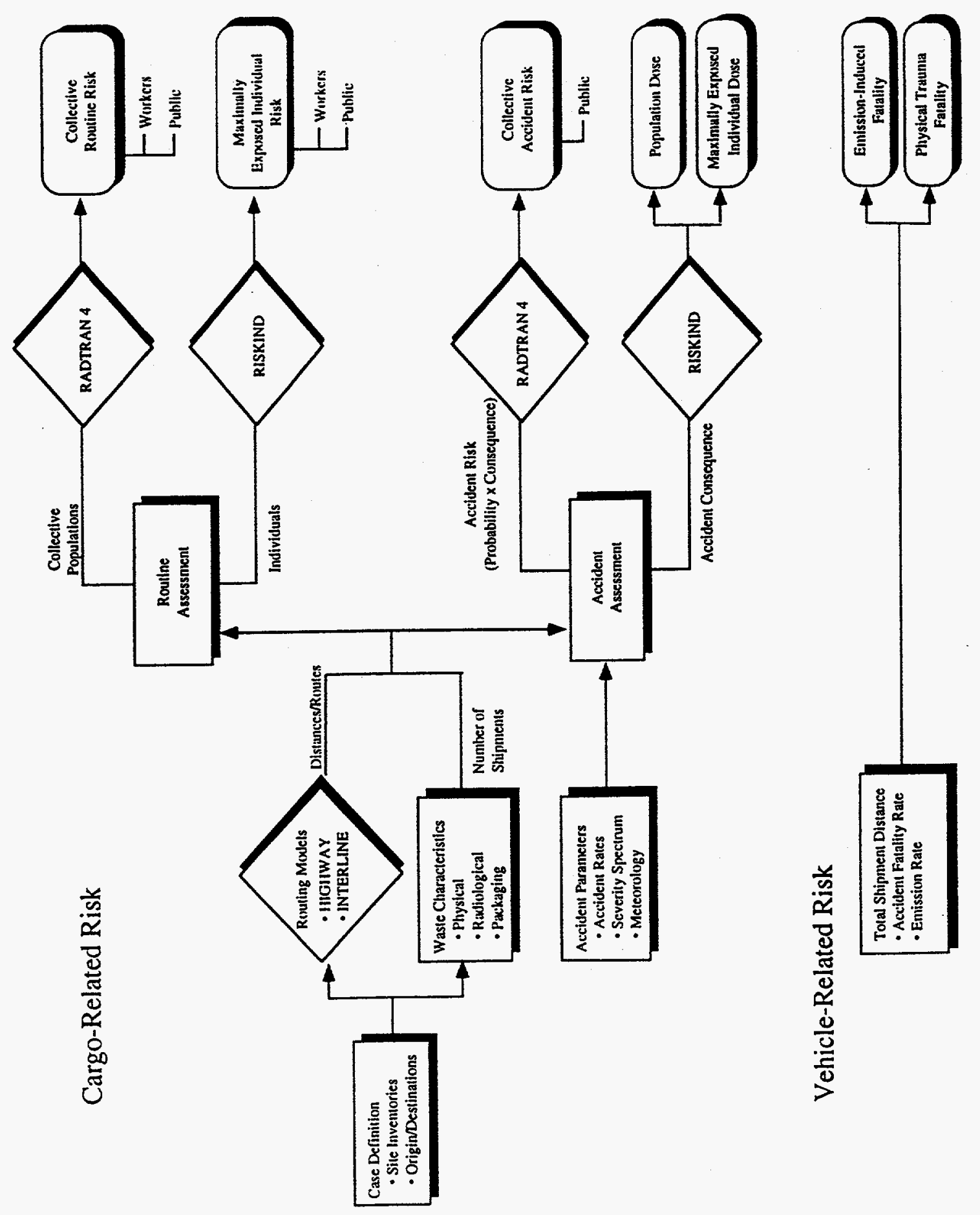

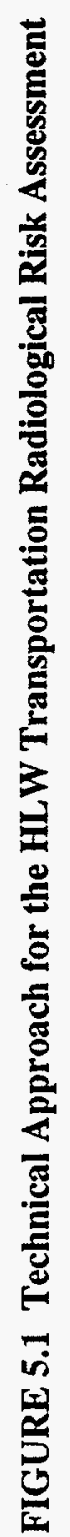


The RISKIND calculations are conducted for the WM PEIS to supplement the results for collective risk calculated with RADTRAN 4 . Whereas the results for collective risk provide a measure of the overall risks of each alternative, the RISKIND calculations are meant to address areas of specific concern to individuals and subgroups of population. Essentially, the RISKIND analyses are meant to address "what if" questions, such as, "What if I live next to a site access road?" or "What if an accident happens near my town?"

\subsection{ROUTINE (INCIDENT-FREE) RISK ASSESSMENT METHOD}

\subsubsection{Collective Population Risk}

The radiological risk associated with routine transportation results from the potential exposure of people to low-level external radiation in the vicinity of loaded shipments. Since the radiological consequences (dose) occur as a direct result of normal operations, the probability of routine consequences is taken to be unity in the RADTRAN 4 code. The maximum allowable external dose rates for exclusive-use shipments were presented in Section 3.

For routine transportation, the RADTRAN 4 computer code considers all major groups of potentially exposed persons. The RADTRAN 4 calculations of risk for routine highway and rail transportation include exposures of the following population groups:

1. Persons along the Route (Off-Link Population). Collective doses are calculated for all persons living or working within $0.8 \mathrm{~km}(0.5 \mathrm{mi})$ of each side of a transportation route. The total number of persons within the $1.6-\mathrm{km}$ (1-mi) corridor is calculated separately for each route considered in the assessment.

2. Persons Sharing the Route (On-Link Population). Collective doses are calculated for persons in all vehicles sharing the transportation route. This group includes persons traveling in the same or opposite directions as the shipment, as well as persons in vehicles passing the shipment.

3. Persons at Stops. Collective doses are calculated for people who may be exposed while a shipment is stopped en route. For truck transportation, these stops include those for refueling, food, and rest. For rail transportation, stops are assumed to occur for purposes of classification.

4. Crew Members. Collective doses are calculated for truck and rail transportation crew members involved in the actual shipment of waste. Workers involved in loading or unloading are not considered. 
The doses calculated for the first three population groups are added together to yield the collective dose to the general public; the dose calculated for the fourth group represents the collective dose to workers. The RADTRAN 4 models for routine dose are not intended for estimating specific risks to individuals.

The RADTRAN 4 calculations for routine dose are based on generically expressing the dose rate as a function of distance from a point source (Neuhauser and Kanipe 1993). Associated with the calculation of routine doses for each exposed population group are parameters such as the radiation field strength, source-receptor distance, duration of exposure, vehicular speed, stopping time, traffic density, and route characteristics such as population density. The RADTRAN manual contains derivations of the equations and descriptions of these parameters (Neuhauser and Kanipe 1993). The values for many of the most important parameters are presented in Section 6.

The collective routine risks are calculated for each $\mathrm{HLW}$ case as follows. Each case is first defined as a set of origin-destination pairs. Representative highway and rail routes are determined for each unique pair as described in Section 4. The number of shipments transported across each linkage is then calculated for both truck and rail modes by dividing the estimated site-specific canister inventories by one canister per cask for truck shipments and five canisters per cask for rail shipments (rail shipments are assumed to consist of one railcar per shipment). For shipments between each origin-destination pair, RADTRAN 4 is used to calculate the collective risks to workers and the public on the basis of representative radiological and physical properties of the HLW. The collective risks are then summed over the set of origin-destination pairs to estimate the collective routine risks associated with that alternative.

\subsubsection{Maximally Exposed Individual Risk}

In addition to the assessment of the routine collective population risk, the risk to MEIs has been estimated for a number of hypothetical exposure scenarios by using RISKIND. The receptors include transportation crew members, departure inspectors, and members of the public exposed during traffic delays, while working at a service station, or while living near a DOE site.

The dose to each MEI considered is calculated with RISKIND for an exposure scenario defined by a given distance, duration, and frequency of exposure specific to that receptor. The distances and durations of exposure are similar to those given in previous transportation risk assessments (DOE 1987b, 1990a) and are presented in Section 6. The scenarios are not meant to be exhaustive but were selected to provide a range of potential exposure situations.

The RISKIND external dose model considers direct external exposure and exposure from radiation scattered from the ground and air. RISKIND is used to calculate the dose as a function of distance (millirem per hour for stationary exposures and millirem per event for moving shipments) from a HLW shipment on the basis of the dimensions of the shipment. The code approximates the shipment as a cylindrical volume source; and the calculated dose includes contributions from 
secondary radiation scattering from buildup (scattering by waste contents), cloudshine (scattering by the air), and groundshine (scattering by the ground). The dose rates calculated by using RISKIND have been shown to be comparable with output from existing shielding codes for various waste configurations. As a conservative measure, credit for potential shielding between the cask and the receptor is not considered.

\subsubsection{Vehicle-Related (Nonradiological) Routine Risk}

Vehicle-related health risks resulting from routine transport may be associated with the generation of air pollutants by transport vehicles during HLW shipment and are independent of the radioactive nature of the shipment. The health end point assessed under routine transport conditions is the excess latent mortality due to inhalation of vehicle exhaust emissions. Risk factors for pollutant inhalation in terms of latent mortality have been generated by Rao et al. (1982). These risk factors are $1 \times 10^{-7}$ mortality $/ \mathrm{km}\left(1.6 \times 10^{-7} / \mathrm{mi}\right)$ and $1.3 \times 10^{-7}$ mortality $/ \mathrm{km}\left(2.1 \times 10^{-7} / \mathrm{mi}\right)$ of truck and rail travel in urban areas, respectively. The risk factors are based on regression analyses of the effects of sulfur dioxide and particulate releases from diesel exhaust on mortality rates. Excess latent mortalities are assumed to be equivalent to latent cancer fatalities. Vehicle-related risks from routine transportation are calculated for each alternative by multiplying the total distance traveled in urban areas by the appropriate risk factor. Similar data are not available for rural and suburban areas.

Risks are summed over the entire route and over all shipments for each HLW alternative. This method has been used in several reports to calculate risks from routine transport of radioactive wastes (DOE 1986, 1987a, 1990a). Lack of information for rural and suburban areas is an obvious data gap, although the risk factor would presumably be lower because of lower total emissions from all sources and lower population densities in rural and suburban areas.

\subsection{ACCIDENT ASSESSMENT METHOD}

\subsubsection{Radiological Accident Risk Assessment}

The risk analysis for potential accidents differs fundamentally from the risk analysis for routine transportation because occurrences of accidents are statistical in nature. The accident risk assessment is treated probabilistically in RADTRAN 4. Accident risk is defined as the product of the accident consequence (dose) and the probability of the accident occurring. In this respect, the RADTRAN 4 code estimates the collective accident risk to populations by considering a spectrum of transportation-related accidents. The spectrum of accidents is designed to encompass a range of possible accidents, including low-probability accidents that have high consequences, and highprobability accidents that have low consequences (such as "fender benders"). The results for collective accident risk can be directly compared with the results for routine collective risk because they incorporate the probabilities of accident occurrences. 
The RADTRAN 4 calculation of collective accident risk employs models that quantify the range of potential accident severities and the responses of transported packages to accidents. The spectrum of accident severity is divided into a number of categories. Each category of severity is assigned a conditional probability of occurrence - that is, the probability that an accident will be of a particular severity if an accident occurs. The more severe the accident, the more remote the chance of its occurrence. Release fractions, defined as the fraction of the material in a package that could be released in an accident, are assigned to each accident severity category on the basis of the physical and chemical form of the waste material. The models take into account the mode of transportation and the type of packaging being considered. The accident rates, the definition of accident severity categories, and the release fractions used in this analysis are discussed further in Section 6.

For accidents involving the release of radioactive material, RADTRAN 4 assumes that the material is dispersed in the environment according to standard Gaussian diffusion models. For the risk assessment, default data for atmospheric dispersion were used, representing an instantaneous ground-level release and a small-diameter source cloud (Neuhauser and Kanipe 1993). The calculation of the collective population dose following the release and dispersal of radioactive material includes the following exposure pathways:

- External exposure to the passing radioactive cloud,

- External exposure to contaminated ground,

- Internal exposure from inhalation of airborne contaminants, and

- Internal exposure from the ingestion of contaminated food.

For the pathway of ingestion, state-specific food transfer factors, which relate the amount of radioactive material ingested to the amount deposited on the ground, were calculated in accordance with the methods described by the NRC Regulatory Guide 1.109 (NRC 1977b) and were used as input to the RADTRAN code. Doses of radiation from the ingestion or inhalation of radionuclides are calculated by using standard dose conversion factors (DOE 1988a,b).

The collective accident risk for each alternative is determined in a manner similar to that described for routine collective risks. Accident risks are first calculated for each unique origindestination pair and then are summed over all pairs to estimate the total risk for the alternative. The accident risk assessment uses site-specific and waste-type-specific radiological and physical waste characteristics. In addition, the assessment uses route-specific information on population density and accident rates derived for individual states. 


\subsubsection{Radiological Accident Consequence Assessment}

The RISKIND code is used to provide a scenario-specific assessment of radiological consequences of severe transportation-related accidents. Whereas the RADTRAN 4 accident risk assessment considers the entire range of accident severities and their related probabilities, the RISKIND accident consequence assessment focuses on accidents that result in the largest release of radioactive material to the environment.

Accident consequences are presented for a shipment of waste that represents the highest potential radiological risk if an accident occurs. This "worst-case" waste is identified by screening the site-specific radiological waste characteristics (that is, activity concentrations) developed for the WM PEIS, taking into account the physical forms of waste and the relative hazards of individual radionuclides. For the majority of waste shipments, the consequences of severe accidents would be less than those presented for the "worst-case" waste. The accident consequence assessment is intended to provide an estimate of the maximum potential impacts posed by a severe transportationrelated accident.

The severe accidents considered in the consequence assessment are characterized by extreme mechanical and thermal forces. In all cases, these accidents result in a release of radioactive material to the environment. The accidents correspond to those within the highest accident severity category, as described previously. These accidents represent low-probability, high-consequence events. The probability of accidents of this magnitude occurring for each alternative depends on the total shipping distance for the alternative; however, accidents of this severity are expected to be extremely rare in general.

RISKIND was used for the accident consequence assessment for two reasons. First, the code has the ability to model the complex atmospheric (or site-specific) dispersion present in severe accidents. The atmospheric dispersion is modeled as an instantaneous release by using standard Gaussian puff methods. In addition, because severe accidents routinely involve fires, modeling of the potential radiological consequences takes into account physical phenomena resulting from the fire, such as buoyant plume rise. Second, RISKIND can be used to estimate the dose to maximally exposed individuals (MEIs) in the vicinity of an accident. The location of the MEI is determined by RISKIND on the basis of the atmospheric conditions assumed at the time of the accident and the thermal characteristics of the release.

The accident consequences are calculated for both local populations and MEIs. The population dose includes the population within $80 \mathrm{~km}(50 \mathrm{mi})$ of the site of the accident. The exposure pathways considered are similar to those discussed previously for the accident risk assessment. Although remedial activities after the accident (for example, evacuation or ground cleanup) would reduce the consequences of an accident, these activities were not given credit in the consequence assessment. 
Because predicting the exact location of a severe transportation-related accident is impossible, separate accident consequences are calculated for accidents occurring in rural, suburban, and urban zones of population density. Moreover, to address the effects of the atmospheric conditions existing at the time of an accident, two different atmospheric conditions are considered. The first case assumes neutral atmospheric conditions, and the second assumes stable conditions. Atmospheric conditions are discussed further in Section 6.

\subsubsection{Vehicle-Related (Nonradiological) Accident Risk Assessment}

The vehicle-related accident risk refers to the potential for transportation-related accidents that directly result in fatalities that are not related to the cargo in the shipment. This risk represents fatalities from mechanical causes. State-specific transportation fatality rates are used in the assessment and are discussed in Section 6. Vehicle-related accident risks are calculated for each alternative by multiplying the total distance traveled in each state by the appropriate state rate for transportation-related fatalities. In all alternatives, the vehicle-related accident risks are calculated by using distances for round-trip shipment. 


\section{INPUT PARAMETERS AND ASSUMPTIONS}

The transportation risk assessment is designed to ensure - through uniform and judicious selection of models, data, and assumptions - that relative comparisons of risk among the various alternatives are meaningful. This goal is accomplished by uniformly applying common input parameters and assumptions to all alternatives. The major input parameters and assumptions used in the HLW transportation risk assessment are discussed in this section.

\subsection{SHIPMENT EXTERNAL DOSE RATE}

The dose (and, correspondingly, the risk) to populations and MEIs during routine transportation is directly proportional to the external dose rate from the shipment. The federal regulations for maximum allowable external dose rates for exclusive-use shipments were presented in Section 3. The actual shipment dose rate is a complex function of the composition and configuration of shielding and containment materials used in the waste packaging, the geometry of the loaded shipments, and the characteristics of the waste material itself.

For HLW shipments, the external dose rate has been assumed to be equal to the regulatory limit of $10 \mathrm{mrem} / \mathrm{h}$ at $2 \mathrm{~m}(6.6 \mathrm{ft})$ for all shipments. The regulatory limit was assumed because extensive historical data for HLW shipments do not exist. In addition, the regulatory limit is believed to be reasonable for future HLW shipments because of the relatively large amount of radioactivity in vitrified HLW and because designing casks to maximize shipment capacities is generally desirable. In practice, the dose rates may vary from site to site and from shipment to shipment at a given site and may range well below the regulatory limit assumed for this assessment. Therefore, the assumption that the dose rates are equal to the regulatory limit provides a conservative estimate.

\subsection{POPULATION DENSITY ZONES}

Three zones of population density (that is, rural, suburban, and urban) were used for the offsite population risk assessment, with the fractions of travel in each zone determined by the HIGHWAY and INTERLINE routing models. The rural, suburban, and urban zones correspond to mean population densities of $6 / \mathrm{km}^{2}\left(15.5 / \mathrm{mi}^{2}\right), 719 / \mathrm{km}^{2}\left(1,862 / \mathrm{mi}^{2}\right)$, and $3,861 / \mathrm{km}^{2}\left(10,000 / \mathrm{mi}^{2}\right)$, respectively. The three population density zones are based on an aggregation of the 12 population density zones provided in the HIGHWAY and INTERLINE model outputs. For calculation purposes, information on population density was generated at the state level and used as RADTRAN input for all origin-destination pairs. 


\subsection{ACCIDENT RATES}

For the calculation of accident risks, vehicle accident and fatality rates are taken from data provided in Saricks and Kvitek (1994). For each transport mode, accident rates are generically defined as the number of accident involvements (or fatalities) in a given year per unit of travel of that mode in that same year. Therefore, the rate is a fractional value, with accident-involvement count as the numerator of the fraction and vehicular activity (total travel distance) as its denominator. Accident rates are generally determined for a multiyear period. For assessment purposes, the total number of expected accidents or fatalities is calculated by multiplying the total shipment distance for a specific case by the appropriate accident or fatality rate.

For truck transportation, the rates presented in Saricks and Kvitek (1994) are specifically for heavy combination trucks involved in interstate commerce. Heavy combination trucks are rigs composed of a separable tractor unit containing the engine and one to three freight trailers connected to each other. Heavy combination trucks are typically used for radioactive waste shipments. The truck accident rates are computed for each state on the basis of statistics compiled by the DOT Office of Motor Carriers for 1986-1988. Saricks and Kvitek (1994) present accident involvement and fatality counts, estimated kilometers of travel by state, and the corresponding average accident involvement, fatality, and injury rates for the 3 years investigated. Fatalities are deaths (including crew members) that are attributable to the accident and that occurred at any time within 30 days thereafter. The truck accident rates are summarized in Table 6.1.

Rail accident rates are computed and presented similarly to truck accident rates in Saricks and Kvitek (1994); however, the unit of haulage is considered to be the railcar. Saricks and Kvitek base their state-specific rail accident involvement and fatality rates on statistics compiled by the Federal Railroad Administration for 1985-1988. Rail accident rates include both mainline accidents and those occurring in railyards. The rail accident rates are summarized in Table 6.2.

It is important to note that the accident rates used in this assessment were computed using the universe of all interstate shipments, independent of shipment cargo. Saricks and Kvitek (1994) point out that shippers and carriers of radioactive material generally have a higher-than-average awareness of transport risk and prepare cargoes and drivers for such shipments accordingly. This preparation should have a twofold effect of reducing component/equipment failure and mitigating the "human error" contribution to accident causation. These effects were not given credit in the accident assessment. 
TABLE 6.1 Highway Combination-Truck Accident, Fatality, and Injury Rates by Road Type ${ }^{\text {a }}$ Based on Reportable Interstate-Carrier Accidents, Reported Fatalities and Injuries, and Estimated Flows, 1986-1988 $\left(10^{-7}\right.$ accidents and injuries per shipment-kilometer, $10^{-8}$ fatalities per shipment-kilometer)

\begin{tabular}{|c|c|c|c|c|c|c|c|c|c|c|c|c|c|c|c|}
\hline \multirow[b]{2}{*}{ Statel } & \multicolumn{5}{|c|}{ Accident-Involvement Rates } & \multicolumn{5}{|c|}{ Accident-Fatality Rates } & \multicolumn{5}{|c|}{ Accident-Injury Rates } \\
\hline & FAI-U & FAI-R & FAI & FAP & FAS & FAI-U & FAI-R & FAI & FAP & FAS & FAI-U & FAI-R & FAI & FAP & FAS \\
\hline $\mathrm{AL}$ & 4.68 & 1.26 & 1.85 & 5.16 & 3.96 & 3.29 & 1.84 & 2.09 & 6.34 & 7.84 & 4.66 & 1.24 & 1.83 & 5.62 & 4.22 \\
\hline $\mathrm{AZ}$ & 2.71 & 1.60 & 1.76 & 2.12 & 1.45 & 3.56 & 2.13 & 2.33 & 4.97 & 1.20 & 2.89 & 1.65 & 1.82 & 2.20 & 2.77 \\
\hline AR & 4.82 & 1.73 & 2.09 & 4.69 & 6.84 & 6.61 & 2.28 & 2.78 & 8.88 & 7.10 & 4.09 & 1.95 & 2.20 & 4.38 & 5.94 \\
\hline $\mathrm{CA}$ & 1.92 & 1.64 & 1.76 & 1.15 & 2.22 & 1.39 & 2.56 & 2.06 & 1.98 & 3.81 & 1.82 & 1.68 & 1.74 & 1.12 & 2.67 \\
\hline $\mathrm{CO}$ & 6.28 & 2.76 & 3.60 & 4.11 & 4.42 & 3.38 & 2.45 & 2.67 & 6.58 & 5.83 & 5.47 & 2.82 & 3.45 & 3.95 & 3.67 \\
\hline CT & 2.67 & $4.60^{c}$ & 3.23 & 2.56 & 9.09 & 1.01 & $5.11^{\mathrm{c}}$ & 2.20 & 1.17 & 9.09 & 1.71 & $4.61^{\mathrm{c}}$ & 2.55 & 1.89 & 7.09 \\
\hline $\mathrm{DE}$ & 2.56 & -- & 2.56 & 7.35 & 4.81 & 1.66 & -- & 1.66 & $13.50^{\mathrm{c}}$ & 7.69 & 3.46 & -. & 3.46 & 7.18 & 3.08 \\
\hline FL & 2.25 & 1.21 & 1.50 & 3.73 & 6.33 & 1.74 & 2.62 & 2.38 & 5.92 & 6.12 & 2.36 & 1.28 & 1.58 & 4.12 & 7.92 \\
\hline GA & 4.87 & 1.65 & 2.28 & 6.15 & 4.04 & 2.37 & 1.86 & 1.96 & 8.30 & 6.74 & 4.37 & 1.75 & 2.26 & 6.43 & 3.71 \\
\hline ID & 1.73 & 2.30 & 2.22 & 4.93 & 2.29 & 0 & 2.06 & 1.78 & 7.46 & 2.54 & 1.18 & 2.12 & 1.99 & 3.54 & 1.69 \\
\hline IL & $8.75^{\mathfrak{c}}$ & 1.76 & 3.53 & 6.40 & 1.78 & 5.33 & 1.39 & 2.38 & 7.84 & 2.30 & $8.23^{\mathrm{c}}$ & 1.49 & 3.20 & 6.12 & 1.55 \\
\hline IN & 4.58 & 1.92 & 2.43 & 4.72 & 2.80 & 3.51 & 1.22 & 1.66 & 7.66 & 4.02 & 4.36 & 1.81 & 2.30 & 4.42 & 2.32 \\
\hline IA & 3.54 & 1.78 & 2,02 & 4.03 & 1.24 & 2.68 & 1.05 & 1.26 & 6.14 & 0.73 & 3.78 & 1.46 & 1.76 & 3.48 & 0.88 \\
\hline $\mathrm{KS}$ & 4.48 & 2.04 & 2.56 & 5.11 & 1.38 & 5.52 & 1.88 & 2.66 & 9.35 & 1.72 & 3.66 & 1.91 & 2.28 & 4.09 & 1.12 \\
\hline KY & 5.13 & 1.46 & 1.99 & 5.74 & 8.80 & 3.22 & 1.50 & 1.75 & 6.60 & 6.25 & 5.52 & 1.33 & 1.94 & 5.28 & 8.12 \\
\hline LA & 3.54 & 1.30 & 1.88 & 3.53 & 2.39 & 4.90 & 1.77 & 2.59 & 5.73 & 3.28 & 4.57 & 1.32 & 2.16 & 4.46 & 2.85 \\
\hline $\mathrm{ME}$ & $9.03^{\mathrm{c}}$ & 2.44 & 2.93 & 5.44 & 2.28 & 0 & 2.34 & 2.16 & 6.58 & 2.17 & 4.52 & 1.53 & 1.75 & 5.00 & 1.63 \\
\hline MD & 3.08 & 3.95 & 3.46 & 3.56 & 12.40 & 1.62 & 4.03 & 2.69 & 3.66 & 8.99 & 3.41 & 3.98 & $3.66^{\mathrm{c}}$ & 4.32 & 13.40 \\
\hline MA & 1.42 & $6.47^{\mathrm{c}}$ & 2.68 & 3.43 & $46.10^{\mathrm{c}}$ & 1.30 & $6.23^{\mathrm{c}}$ & 2.53 & 3.93 & $52.20^{\mathrm{c}}$ & 1.13 & $4.99^{c}$ & 2.09 & 3.02 & $43.90^{\mathrm{c}}$ \\
\hline MI & 3.16 & 1.59 & 2.12 & 2.68 & 0.81 & 1.52 & 1.23 & 1.33 & 3.96 & 1.22 & 3.04 & 1.29 & 1.87 & 2.61 & 1.38 \\
\hline MN & 2.66 & 2.06 & 2.29 & 4.19 & 2.16 & 2.02 & 1.72 & 1.83 & 7.69 & 7.84 & 2.08 & 1.46 & 1.69 & 3.28 & 1.86 \\
\hline MS & 2.01 & 1.19 & 1.35 & 4.48 & 0.65 & 2.46 & 1.81 & 1.93 & 9.26 & 1.62 & 1.85 & 1.10 & 1.25 & 4.55 & 0.50 \\
\hline MO & 5.18 & 1.78 & 2.61 & 5.36 & 2.49 & 4.30 & 1.23 & 1.99 & 9.68 & 3.25 & 5.53 & 1.63 & 2.59 & 5.06 & 2.23 \\
\hline $\mathrm{MT}$ & $10,00^{\mathrm{c}}$ & 2.52 & 2.89 & 5.38 & 1.02 & 3.12 & 1.44 & 1.52 & 7.97 & 2.04 & 4.69 & 1.79 & 1.93 & 3.95 & 0.20 \\
\hline $\mathrm{NE}$ & 6.97 & 1.77 & 2.09 & 3.62 & 0.99 & 6.58 & 1.10 & 1.43 & 5.75 & 0 & 6.58 & 1.17 & 1.50 & 3.54 & 0.54 \\
\hline NV & 6.33 & 1.57 & 1.97 & 4.35 & 3.17 & $8.89^{\mathrm{c}}$ & 1.14 & 1.79 & 10.50 & 7.94 & 5.67 & 1.58 & 1.93 & 3.72 & 2.54 \\
\hline NH & 0.22 & 1.39 & 1.18 & 4.36 & 3.33 & 0 & 1.49 & 1.22 & 5.77 & 5.56 & 0 & 1.14 & 0.94 & 4.17 & 2.22 \\
\hline
\end{tabular}


TABLE 6.1 (Cont.)

\begin{tabular}{|c|c|c|c|c|c|c|c|c|c|c|c|c|c|c|c|}
\hline \multirow[b]{2}{*}{ State $^{b}$} & \multicolumn{5}{|c|}{ Accident-Involvement Rates } & \multicolumn{5}{|c|}{ Accident-Fatality Rates } & \multicolumn{5}{|c|}{ Accident-Injury Rates } \\
\hline & FAI-U & FAI-R & FAI & FAP & FAS & FAI-U & FAI-R & FAI & FAP & FAS & FAI-U & FAI-R & FAI & FAP & FAS \\
\hline NJ & 2.77 & $7.65^{\mathrm{C}}$ & $4,24^{\mathrm{c}}$ & 6.80 & 9.69 & 1.56 & $6.56^{\mathrm{c}}$ & 3.06 & 4.57 & 11.50 & 2.69 & $8.00^{c}$ & $4.28^{c}$ & 6.86 & 11.30 \\
\hline NM & $9.64^{\mathrm{c}}$ & 1.92 & 2.35 & 4.77 & 12.20 & $9.01^{\mathrm{c}}$ & 1.93 & 2.32 & 6.99 & 5.56 & $8.92^{\mathrm{c}}$ & 1.86 & 2.25 & 4.62 & 10.60 \\
\hline NY & 5.69 & 2.93 & $3.98^{\mathfrak{c}}$ & 3.16 & 9.48 & 2.04 & 1.38 & 1.63 & 4.61 & 10.30 & 4.49 & 2.56 & 3.28 & 2.71 & 10.00 \\
\hline NC & 5.92 & 2.28 & 2.97 & 5.17 & 6.37 & 5.08 & 2.92 & $3.33^{\mathrm{c}}$ & 6.71 & 11.00 & 6.37 & 2.19 & 2.99 & 5.53 & 6.22 \\
\hline $\mathrm{OH}$ & 3.16 & 2.27 & 2.52 & 4.42 & 11.00 & 1.41 & 1.32 & 1.35 & 6.07 & 9.88 & 2.85 & 2.02 & 2.25 & 4.40 & 1070 \\
\hline OK & 3.76 & 1.47 & 1.91 & 3.61 & 1.73 & 2.70 & 2.06 & 2.18 & 4.88 & 0.71 & 3.34 & 1.36 & 1.74 & 3.05 & 1.59 \\
\hline OR & 3.99 & 2.20 & 2.48 & 4.17 & 1.63 & 2.47 & 1.12 & 1.33 & 5.85 & 4.07 & 3.82 & 1.69 & 2.02 & 2.94 & 0.57 \\
\hline PA & 3.02 & 3.60 & 3.48 & 7.21 & 7.92 & 2.12 & 2.97 & 2.79 & 10.20 & 9.29 & 2.68 & 3.28 & 3.15 & 7.28 & 6.42 \\
\hline RI & 2.27 & 1.98 & 2.16 & 1.37 & 16.70 & 0.71 & 3.70 & 1.80 & 1.71 & $66.70^{\mathrm{c}}$ & 3.12 & 2.35 & 2.84 & 0.86 & $23.30^{\mathrm{c}}$ \\
\hline SC & 3.13 & 1.83 & 1.99 & 6.27 & 2.27 & 2.88 & 2.57 & 2.61 & 8.61 & 3.95 & 2.65 & 2.20 & 2.26 & 6.96 & 2.27 \\
\hline SD & $8.57^{\mathrm{C}}$ & 2.09 & 2.18 & 3.94 & 1.49 & $14.30^{\mathrm{C}}$ & 0.42 & 0.62 & 5.38 & 2.13 & 5.71 & 1.38 & 1.95 & 2.94 & 0 \\
\hline TN & 7.97 & 1.48 & 2.48 & 5.56 & 6.26 & 5.59 & 1.63 & 2.24 & 6.97 & 12.10 & $7.70^{\mathrm{c}}$ & 1.44 & 2.41 & 5.85 & 4.67 \\
\hline TX & 2.74 & 1.56 & 2.00 & 2.78 & 1.09 & 1.93 & 1.97 & 1.95 & 4.77 & 1.84 & 2.53 & 1.42 & 1.83 & 2.53 & 0.92 \\
\hline VT & 0 & 1.38 & 1.33 & 6.30 & 6.80 & 0 & 0.43 & 0.42 & 3.36 & 24.00 & 0 & 1.08 & 1.04 & 6.13 & 4.40 \\
\hline VA & 2.63 & 2.54 & 2.56 & 4.67 & 5.03 & 1.91 & 1.76 & 1.80 & 7.28 & 7.73 & 2.49 & 2.46 & 2.47 & 5.39 & 4.81 \\
\hline WA & 1.61 & 2.50 & 2.10 & 2.62 & 0.73 & 0.80 & 1.47 & 1.17 & 2.54 & 0 & 1.49 & 2.14 & 1.85 & 2.11 & 0.51 \\
\hline WV & 2.95 & 3.10 & 3.07 & $11.70^{\mathrm{c}}$ & 7.87 & 1.28 & 1.67 & 1.60 & $17.80^{\mathrm{c}}$ & 1.70 & 2.78 & 2.80 & 2.79 & $9.91^{\mathrm{c}}$ & 7.13 \\
\hline WI & 5.29 & 1.74 & 2.18 & 2.80 & 3.24 & 0.77 & 0.66 & 0.67 & 3.62 & 3.68 & 4.33 & 1.45 & 1.81 & 2.51 & 3.16 \\
\hline WY & 2.98 & 3.42 & 3.40 & 3.41 & 3.70 & 0 & 2.08 & 2.01 & 6.22 & 3.70 & 0 & 2.84 & 2.74 & 1.86 & 2.35 \\
\hline USA & 3.58 & 2.03 & 2.44 & 3.94 & 3.48 & 2.37 & 1.91 & 2.03 & 5.82 & 4.62 & 3.36 & 1.89 & 2.28 & 3.82 & 3.30 \\
\hline$\sigma^{d}$ & 2.36 & 1.25 & 0.69 & 1.77 & 6.98 & 2.70 & 1.27 & 0.63 & 3.01 & 11.74 & 1.99 & 1.22 & 0.69 & 1.79 & 7.10 \\
\hline
\end{tabular}

a $\quad \mathrm{FAI}=$ Federally aided interstate

$$
\begin{aligned}
& U=\text { Urban } \\
& R=\text { Rural }
\end{aligned}
$$

FAP $=$ Federally aided primary

FAS $=$ Federally aided secondary

b Includes only the $\mathbf{4 8}$ contiguous states, plus the totals for the United States.

c Rates are two or more standard deviations greater than the national average rate for that highway category.

d $\sigma=$ standard deviation.

Source: Saricks and Kvitek (1994). 
TABLE 6.2 Railroad-Freight-Car Accident Rates, by State, for 1986, 1987, 1988, and 1985-1988 Combined $\left(10^{-8}\right.$ accidents per railcar-kilometer $\left.{ }^{a}\right)$

\begin{tabular}{|c|c|c|c|c|c|c|c|c|}
\hline \multirow[b]{2}{*}{ State $^{b}$} & \multicolumn{2}{|c|}{1986} & \multicolumn{2}{|c|}{1987} & \multicolumn{2}{|c|}{1988} & \multicolumn{2}{|c|}{$1985-88$} \\
\hline & Total & $\begin{array}{l}\text { Main } \\
\text { Only } \\
\end{array}$ & Total & $\begin{array}{l}\text { Main } \\
\text { Only }\end{array}$ & Total & $\begin{array}{l}\text { Main } \\
\text { Only } \\
\end{array}$ & Total & $\begin{array}{l}\text { Main } \\
\text { Only }\end{array}$ \\
\hline $\mathrm{AL}$ & 3.88 & 2.00 & 4.80 & 3.37 & 4.13 & 2.52 & 4.80 & 2.75 \\
\hline $\mathrm{AZ}$ & 1.40 & 1.05 & 1.30 & 1.08 & 1.44 & 1.18 & 1.75 & 1.30 \\
\hline $\mathrm{AR}$ & 5.05 & 2.59 & 4.27 & 2.32 & 8.34 & 3.94 & 6.78 & 3.54 \\
\hline $\mathrm{CA}$ & 5.10 & 2.64 & 3.30 & 1.98 & 4.32 & 2.30 & 5.10 & 2.51 \\
\hline $\mathrm{CO}$ & 1.44 & 1.01 & 0.86 & 0.40 & 2.55 & 1.51 & 1.73 & 1.02 \\
\hline $\mathrm{CT}$ & 26.47 & 17.65 & 16.67 & 8.34 & 24.95 & 0 & $28.27^{\mathrm{c}}$ & 10.10 \\
\hline $\mathrm{DE}$ & 27.44 & 9.15 & 25.23 & 16.82 & 18.04 & 18.04 & 17.71 & 11.07 \\
\hline DC & 0 & 0 & 316 & 316 & 0 & 0 & $117.09^{c}$ & $78.06^{\mathrm{c}}$ \\
\hline FL & 2.86 & 2.12 & 3.90 & 1.90 & 4.16 & 2.38 & 4.02 & 2.21 \\
\hline GA & 6.44 & 3.08 & 6.77 & 2.81 & 6.18 & 2.69 & 6.44 & 2.84 \\
\hline ID & 5.90 & 5.25 & 6.74 & 4.10 & 9.03 & 3.99 & 7.01 & 4.14 \\
\hline IL & 11.70 & 3.10 & 9.97 & 3.10 & 9.08 & 2.45 & 10.67 & 2.97 \\
\hline IN & 4.18 & 1.85 & 3.71 & 1.48 & 3.80 & 1.44 & 4.64 & 1.93 \\
\hline IA & 17.63 & 7.15 & 12.72 & 6.65 & 11.95 & 7.01 & 14.67 & 7.16 \\
\hline KS & 3.01 & 1.62 & 2.97 & 1.55 & 4.09 & 1.98 & 3.61 & 1.75 \\
\hline KY & 4.78 & 2.39 & 3.77 & 1.98 & 3.60 & 1.84 & 4.48 & 2.44 \\
\hline LA & 12.67 & 5.98 & 7.07 & 2.02 & 11.94 & 3.92 & 12.37 & 4.28 \\
\hline ME & 28.22 & 16.93 & 29.40 & 13.36 & 52.57 & 26.29 & $37.80^{c}$ & $18.53^{c}$ \\
\hline MD & 6.07 & 3.54 & 5.55 & 2.44 & 4.55 & 1.24 & 5.62 & 2.58 \\
\hline MA & 12.33 & 5.87 & 10.06 & 3.71 & 7.31 & 2.81 & 11.65 & 4.97 \\
\hline MI & 18.34 & 8.18 & 15.10 & 4.42 & 15.52 & 7.45 & 16.47 & 7.19 \\
\hline MN & 8.63 & 2.64 & 6.24 & 3.30 & 7.86 & 3.63 & 8.48 & 3.16 \\
\hline MS & 15.16 & 11.20 & 12.93 & 9.84 & 8.47 & 7.14 & 11.52 & 8.51 \\
\hline MO & 4.59 & 2.12 & 3.60 & 1.87 & 5.05 & 2.87 & 5.28 & 2.56 \\
\hline $\mathrm{MT}$ & 1.35 & 1.01 & 1.24 & 0.81 & 2.11 & 1.17 & 1.73 & 1.10 \\
\hline $\mathrm{NE}$ & 4.04 & 2.11 & 4.81 & 2.49 & 4.46 & 2.23 & 4.63 & 2.56 \\
\hline NV & 3.27 & 1.87 & 1.29 & 0.86 & 3.97 & 2.65 & 3.23 & 2.19 \\
\hline $\mathrm{NH}$ & 6.60 & 6.60 & 17.52 & 11.68 & 24.27 & 16.18 & 21.45 & $17.16^{\mathrm{c}}$ \\
\hline NJ & 13.86 & 2.64 & 9.44 & 5.31 & 10.10 & 4.75 & 12.38 & 4.82 \\
\hline $\mathrm{NM}$ & 0.90 & 0.52 & 0.93 & 0.75 & 0.86 & 0.65 & 0.94 & 0.66 \\
\hline $\mathrm{NY}$ & 7.23 & 3.92 & 6.80 & 4.14 & 7.26 & 3.36 & 8.32 & 4.30 \\
\hline $\mathrm{NC}$ & 5.40 & 2.70 & 5.48 & 1.62 & 6.29 & 2.95 & 5.70 & 2.27 \\
\hline $\mathrm{ND}$ & 2.18 & 1.48 & 2.43 & 1.86 & 1.49 & 1.12 & 2.41 & 1.80 \\
\hline $\mathrm{OH}$ & 5.35 & 2.50 & 3.55 & 1.58 & 4.04 & 1.92 & 4.73 & 2.12 \\
\hline OK & 5.25 & 3.01 & 3.52 & 1.90 & 3.77 & 1.88 & 4.66 & 2.72 \\
\hline
\end{tabular}


TABLE 6.2 (Cont.)

\begin{tabular}{|c|c|c|c|c|c|c|c|c|}
\hline \multirow[b]{2}{*}{ State $^{b}$} & \multicolumn{2}{|c|}{1986} & \multicolumn{2}{|c|}{1987} & \multicolumn{2}{|c|}{1988} & \multicolumn{2}{|c|}{$1985-88$} \\
\hline & Total & $\begin{array}{l}\text { Main } \\
\text { Only }\end{array}$ & Total & $\begin{array}{l}\text { Main } \\
\text { Only } \\
\end{array}$ & Total & $\begin{array}{l}\text { Main } \\
\text { Only }\end{array}$ & Total & $\begin{array}{l}\text { Main } \\
\text { Only }\end{array}$ \\
\hline OR & 11.74 & 4.96 & 12.23 & 6.12 & 13.64 & 6.04 & 12.48 & 5.77 \\
\hline PA & 4.86 & 3.73 & 4.22 & 2.37 & 3.54 & 1.95 & 4.38 & 2.69 \\
\hline RI & 0 & 0 & 0 & 0 & 0 & 0 & $105.33^{\mathrm{c}}$ & 0 \\
\hline $\mathrm{SC}$ & 4.64 & 2.16 & 4.74 & 3.62 & 5.03 & 3.71 & 5.11 & 3.31 \\
\hline SD & 8.16 & 6.27 & 14.98 & 14.49 & 7.27 & 6.36 & 10.19 & 9.09 \\
\hline $\mathrm{TN}$ & 4.88 & 1.69 & 4.67 & 1.89 & 7.56 & 2.02 & 5.59 & 1.88 \\
\hline $\mathrm{TX}$ & 7.03 & 3.36 & 5.29 & 2.50 & 5.92 & 2.45 & 7.12 & 3.16 \\
\hline UT & 3.69 & 1.34 & 1.85 & 0.93 & 11.19 & 4.04 & 5.78 & 2.31 \\
\hline VT & 5.98 & 2.99 & 7.86 & 5.24 & 24.32 & 18.24 & 15.22 & 11.59 \\
\hline VA & 4.27 & 1.42 & 4.39 & 2.31 & 4.59 & 2.15 & 4.35 & 1.91 \\
\hline WA & 3.65 & 1.38 & 2.69 & 1.50 & 3.57 & 1.12 & 3.49 & 1.44 \\
\hline wV & 11.49 & 9.23 & 9.97 & 7.73 & 6.08 & 4.67 & 9.61 & 7.42 \\
\hline WI & 18.79 & 7.52 & 16.75 & 7.75 & 12.57 & 7.21 & 16.53 & 7.66 \\
\hline WY & 2.55 & 1.37 & 2.61 & 1.47 & 2.88 & 1.40 & 3.10 & 1.97 \\
\hline USA & 5.51 & 2.63 & 4.70 & 2.36 & 5.14 & 2.43 & 5.57 & 2.66 \\
\hline$\sigma^{\mathrm{d}}$ & - & - & - & - & - & - & 21.48 & 11.12 \\
\hline
\end{tabular}

a Nationwide average fatality rate, using count of fatalities consistent with combination-truck fatality counts, is $6.50 \times 10^{-10}$ fatalities per railcar-kilometer. Nationwide average injury rate, using count of injuries consistent with combination-truck injury counts, is $7.83 \times 10^{-8}$ injuries per railcar-kilometer.

b Includes the 48 contiguous states, the District of Columbia, and the totals for the United States.

c Rates are one or more standard deviations greater than the national average rate for that category (i.e., all accidents on carrier-owned track or accidents on main lines only).

d $\sigma=$ standard deviation.

Source: Saricks and Kvitek (1994).

\subsection{ACCIDENT SEVERITY CATEGORIES}

A method to characterize the potential severity of transportation-related accidents is described in an NRC report commonly referred to as NUREG-0170 (NRC 1977a). The NRC method divides the spectrum of transportation accident severities into eight categories. Other studies have divided the same accident spectrum into six categories (Wilmot 1981) and into 20 categories (Fischer et al. 1987); however, these studies focused primarily on accidents involving shipments of spent nuclear fuel and, thus, are not directly applicable to this assessment. 
The NUREG-0170 scheme for accident classification is shown in Figures 6.1 and 6.2 for truck and rail transportation, respectively. Severity is described as a function of the magnitudes of the mechanical forces (impact) and thermal forces (fire) to which a package may be subjected during an accident. Because all accidents can be described in these terms, severity is independent of the specific accident sequence. In other words, any sequence of events that results in an accident in which a package is subjected to forces within a certain range of values is assigned to the accident severity category associated with that range. The scheme for accident severity is designed to take into account all credible transportation-related accidents, including accidents with low probability but high consequences and those with high probability but low consequences.

Each severity category represents a set of accident scenarios defined by a combination of mechanical and thermal forces. A conditional probability of occurrence - that is, the probability that if an accident occurs, it is of a particular severity - is assigned to each category. The fractional occurrences for accidents by the accident severity category and the population density zone are shown in Table 6.3.

Category I accidents are the least severe but the most frequent, whereas category VIII accidents are very severe but very infrequent. To determine the expected frequency of an accident of a given severity, the conditional probability in the category is multiplied by the baseline accident rate. Each population density zone has a distinct baseline accident rate and distribution of accident severities related to differences in average vehicular velocity, traffic density, and other factors, including location (rural, suburban, or urban).

For the accident consequence assessment, the doses were assessed for populations and individuals by assuming an accident of severity category VIII. This accident severity category represents the most severe accident scenarios that can be postulated and that would result in the largest release of radioactive material. Accidents of this severity are extremely rare, occurring approximately once in every 70,000 truck or 100,000 rail accidents involving a shipment of radioactive waste. On the basis of national accident statistics (Saricks and Kvitek 1994), for every $1.6 \mathrm{~km}(1 \mathrm{mi})$ of loaded shipment, the probability of an accident of this severity is $6 \times 10^{-12}$ for shipment by truck and $1 \times 10^{-12}$ for shipment by rail.

\subsection{PACKAGE RELEASE FRACTIONS}

Radiological consequences are calculated by assigning package release fractions to each accident severity category. The release fraction is defined as the fraction of the radioactive material in a package that could be released from the package as the result of an accident of a given severity. Release fractions take into account all mechanisms necessary to create release of radioactive material from a damaged package to the environment. Release fractions vary according to the type of package 


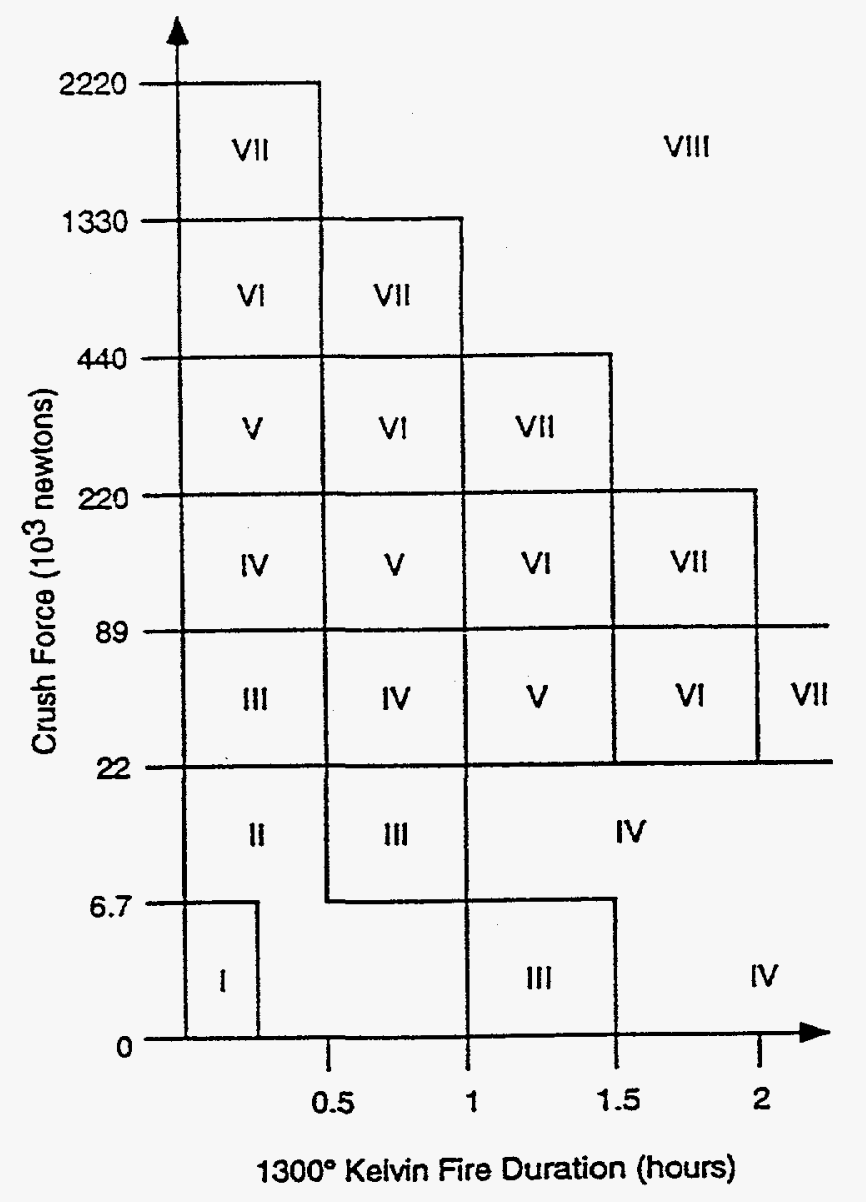

FIGURE 6.1 Scheme for NUREG-0170 Classification by Accident Severity Category for Truck Accidents (Source: NRC 1977a)

and the physical form of the waste. Type B packagings are designed to withstand the forces of severe accidents and therefore have smaller release fractions than Type A packagings.

Representative cask release fractions for HLW shipment accidents were taken from NUREG-0170, primarily because specific release information is not available for the actual casks that will be used to ship HLW. NUREG-0170 recommendations are based on best engineering judgments and have been shown to provide conservative estimates of radioactive material releases following accidents. The release fractions used are those reported in NUREG-0170 for NRC Type B packages. Release fractions for accidents of each severity category are given in Table 6.4.

Also important for the purposes of risk assessment are the fraction of the released material that can be entrained in an aerosol (part of an airborne radioactive plume) and the fraction of the aerosolized material that is also respirable (of a size that can be inhaled into the lungs). These fractions depend on the physical form of the waste material. Most solid wastes, such as vitrified 


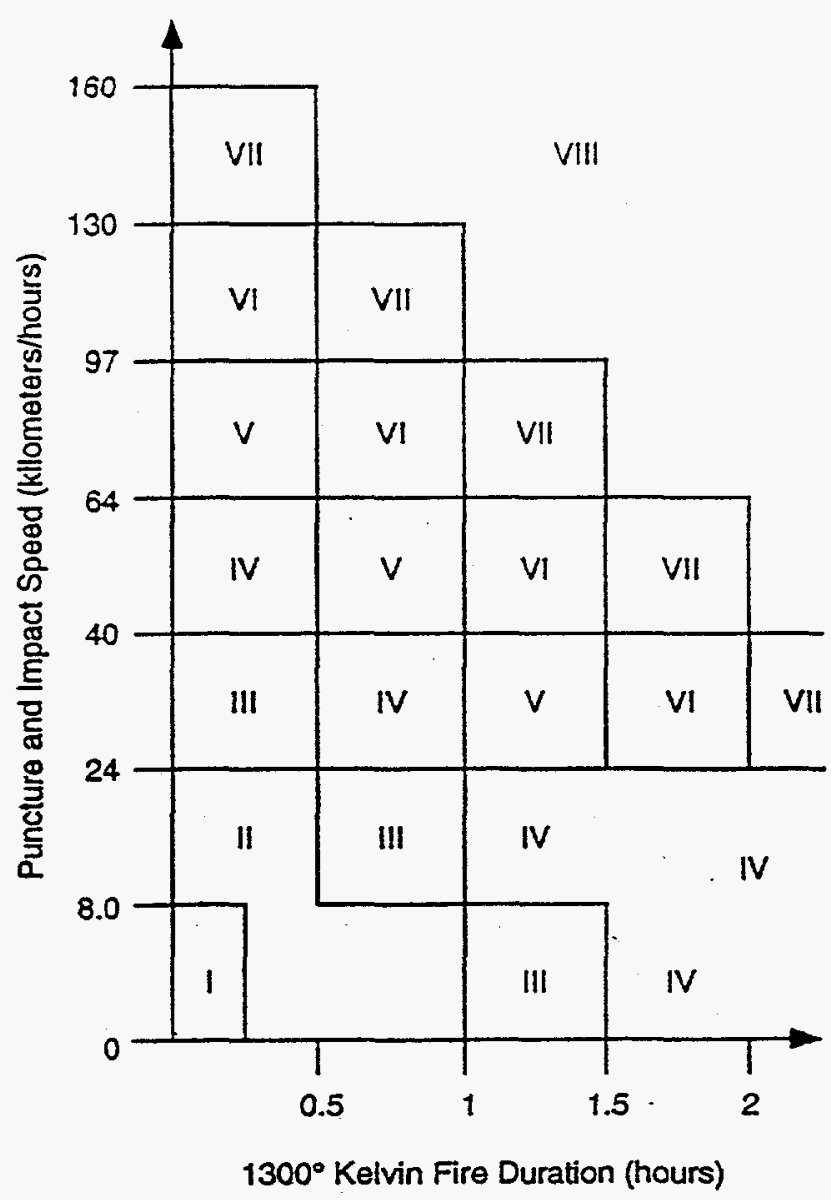

FIGURE 6.2 Scheme for NUREG-0170 Classification by Accident Severity Category for Rail Accidents (Source: NRC 1977a)

HLW, are difficult to release in particulate form and are therefore relatively nondispersible. The fraction of the radioactive material released that can be entrained as an aerosol has been taken as $1.0 \times 10^{-6}$ for vitrified HLW (DOE 1987a; Neuhauser and Kanipe 1993). The respirable fraction of any release is assumed to be $5.0 \times 10^{-2}$ (DOE 1987a; Neuhauser and Kanipe 1993). These values are characteristic of "immobilized" material in the RADTRAN code and are consistent with previous HLW transportation risk assessments.

\subsection{ATMOSPHERIC CONDITIONS}

Radioactive material released to the atmosphere is transported by the wind. Dispersion or dilution of the radioactive material in air depends on meteorologic conditions at the time of the accident. Because predicting the specific location of an off-site transportation-related accident is 
TABLE 6.3 Fractional Occurrences for Accidents by Severity Category and Population Density

Zone

\begin{tabular}{|c|c|c|c|c|}
\hline \multirow{2}{*}{$\begin{array}{l}\text { Severity } \\
\text { Category }\end{array}$} & \multirow{2}{*}{$\begin{array}{c}\text { Fractional } \\
\text { Occurrence } \\
\end{array}$} & \multicolumn{3}{|c|}{$\begin{array}{l}\text { Fractional Occurrence by } \\
\text { Population Density Zone }\end{array}$} \\
\hline & & Rural & Suburban & Urban \\
\hline \multicolumn{5}{|l|}{ Truck } \\
\hline I & 0.55 & 0.1 & 0.1 & 0.8 \\
\hline II & 0.36 & 0.1 & 0.1 & 0.8 \\
\hline III & 0.07 & 0.3 & 0.4 & 0.3 \\
\hline IV & 0.016 & 0.3 & 0.4 & 0.3 \\
\hline V & 0.0028 & 0.5 & 0.3 & 0.2 \\
\hline VI & 0.0011 & 0.7 & 0.2 & 0.1 \\
\hline VII & $8.5 E-05$ & 0.8 & 0.1 & 0.1 \\
\hline VIII & $1.5 \mathrm{E}-05$ & 0.9 & 0.05 & 0.05 \\
\hline \multicolumn{5}{|l|}{ Rail } \\
\hline I & 0.50 & 0.1 & 0.1 & 0.8 \\
\hline II & 0.30 & 0.1 & 0.1 & 0.8 \\
\hline III & 0.18 & 0.3 & 0.4 & 0.3 \\
\hline IV & 0.018 & 0.3 & 0.4 & 0.3 \\
\hline V & 0.0018 & 0.5 & 0.3 & 0.2 \\
\hline VI & $1.3 E-04$ & 0.7 & 0.2 & 0.1 \\
\hline VII & $6.0 \mathrm{E}-05$ & 0.8 & 0.1 & 0.1 \\
\hline VIII & $1.0 \mathrm{E}-05$ & 0.9 & 0.05 & 0.05 \\
\hline
\end{tabular}

Source: NRC (1977a).

impossible, generic atmospheric conditions were selected for the accident risk and consequence assessments.

For the accident risk assessment, neutral weather conditions (represented by Pasquill stability class $D$ with a wind speed of $4 \mathrm{~m} / \mathrm{s}$ [9 $\mathrm{mph}$ ]) were assumed. Because neutral meteorologic conditions constitute the most frequently occurring atmospheric stability condition in the United States, these conditions are most likely to be present in the event of an accident involving an HLW shipment. On the basis of observations from National Weather Service surface meteorologic stations at over 300 locations in the United States, on an annual average, neutral conditions (represented by 
Pasquill Classes C and D) occur about one-half of the time, while stable (Pasquill Classes E and F) and unstable (Pasquill Classes $A$ and B) conditions occur about one-third and one-sixth of the time, respectively (Doty et al. 1976). The neutral category predominates in all seasons but most frequently in the winter (nearly $60 \%$ of the observations). For the accident consequence assessment, doses were assessed under both neutral and stable (Pasquill stability Class F with a wind speed of $1 \mathrm{~m} / \mathrm{s}$ [2.2 $\mathrm{mph}$ ]) atmospheric conditions. The results calculated for neutral conditions represent the most likely consequences, and the results for stable conditions represent a "worst-case" weather situation (i.e., conditions that result in the least amount of dilution and the highest air concentrations of radioactive material).

\subsection{HEALTH RISK CONVERSION FACTORS}

The health risk conversion factors used throughout the WM PEIS to estimate the number of expected cancer-caused fatalities, the incidence of cancer, and the serious genetic effects from radiological exposures were derived from ICRP publication 60 (ICRP 1991): $5.0 \times 10^{-4}$ and $4.0 \times 10^{-4}$ cases of fatal cancer per person-rem for members of the public and for workers, respectively; $1.7 \times 10^{-3}$ and $1.4 \times 10^{-3}$ cases of induced cancer per person-rem for members of the public and for workers, respectively; and $1.0 \times 10^{-4}$ and $6.0 \times 10^{-5}$ adverse genetic effects per person-rem for members of the public and for workers, respectively. Cancer-caused fatalities and the incidence of cancer are determined over the lifetimes of the exposed populations. Genetic effects occur in the descendants of the exposed population; estimates are based on total dose to the reproductive organs. The genetic health risk conversion factors used in this analysis include all generations.
TABLE 6.4 Estimated

Release Fractions for

HLW Shipping Cask

under Various Accident

Severity Categories

\begin{tabular}{cc}
\hline $\begin{array}{c}\text { Severity } \\
\text { Category }\end{array}$ & $\begin{array}{c}\text { Release } \\
\text { Fraction }^{\mathrm{a}}\end{array}$ \\
\hline $\begin{array}{c}\text { Truck } \\
\text { I }\end{array}$ & 0 \\
II & 0 \\
III & 0.01 \\
IV & 0.1 \\
V & 1.0 \\
VI & 1.0 \\
VII & 1.0 \\
VIII & 1.0 \\
& \\
Rail & \\
I & 0 \\
II & 0 \\
III & 0.01 \\
IV & 0.1 \\
V & 1.0 \\
VI & 1.0 \\
VII & 1.0 \\
VIII & 1.0 \\
\hline
\end{tabular}

a Values are for total material release fraction.

Source: NRC (1977a). 


\subsection{MAXIMALLY EXPOSED INDIVIDUAL EXPOSURE SCENARIOS}

The risk to MEIs has been estimated for a number of hypothetical exposure scenarios for HLW shipments. The receptors include crew members, departure inspectors, and members of the public exposed during traffic obstructions (traffic jams), while working at a service station, or by living near a treatment, storage, or disposal site. The dose and risk to MEIs were calculated for given distances and durations of exposure. The distances and durations of exposure for each receptor are similar to those given in previous transportation assessments (DOE 1987b, 1990a). The scenarios for exposure are not meant to be exhaustive but were selected to provide a range of potential situations for exposure. The assumptions for exposure scenarios are as follows:

- Crew Members. Truck and rail crew members are assumed to be occupational radiation workers and would be monitored by a dosimetry program. Therefore, the maximum allowable dose would be $5 \mathrm{rem} / \mathrm{yr}$. As an administrative procedure, the DOE limits doses to DOE workers to $2 \mathrm{rem} / \mathrm{yr}$ (DOE 1992).

- Inspectors (Truck and Rail). Inspectors are assumed to be either federal or state vehicle inspectors. Inspectors are not assumed to be monitored by a dosimetry program. An average exposure distance of $3 \mathrm{~m}(9.8 \mathrm{ft})$ and an exposure duration of 30 minutes are assumed.

- Rail-Yard Crew Member. A rail-yard crew member is not assumed to be monitored by a dosimetry program. An average exposure distance of $10 \mathrm{~m}$ $(32.8 \mathrm{ft})$ and an exposure duration of 2 hours are assumed.

- Resident (Truck and Rail). A resident is assumed to live $30 \mathrm{~m}$ (98 ft) from a site entrance route (truck or rail). Shipments pass at an average speed of $24 \mathrm{~km} / \mathrm{h}(15 \mathrm{mph})$, and the resident is exposed unshielded. Cumulative doses are assessed for each site on the basis of the number of shipments entering or exiting the site, with the assumption that the resident is present for $100 \%$ of the shipments.

- Person in Traffic Obstruction (Truck and Rail). A person is assumed to be stopped next to a waste shipment (e.g., because of traffic slowdown). The person is assumed to be exposed unshielded at a distance of $1 \mathrm{~m}(3.3 \mathrm{ft})$ for a duration of 30 minutes.

- Person at Truck Service Station. A person is assumed to be exposed at an average distance of $20 \mathrm{~m}(65.6 \mathrm{ft})$ for a duration of 2 hours. This receptor could be a worker at a truck stop. 
- Resident near a Rail Stop. A resident is assumed to live near a rail classification yard. The resident is assumed to be exposed unshielded at a distance of $200 \mathrm{~m}(656 \mathrm{ft})$ for a duration of 20 hours.

The largest uncertainty in predicting the dose to MEIs during transportation involves determining the frequency of occurrence of exposures. This difficulty results from the uncertainties in future shipment schedules and route selection and from the inherent uncertainty in predicting the frequency of random or chance events; for instance, that an individual may be stopped in traffic next to a shipment of radioactive waste is conceivable; however, predicting how often the same individual would experience this event is difficult. Therefore, for the majority of receptors considered, doses are assessed on a per-event basis. To account for possible multiple exposures, ranges of realistic total doses are discussed qualitatively. One exception is the calculation of the dose to a hypothetical resident living near an entrance route to a storage or disposal site. For these residents, total doses are calculated on the basis of the number of shipments entering or exiting each site for each case.

\subsection{GENERAL RADTRAN INPUT PARAMETERS}

In addition to the specific parameters discussed previously, values for a number of general parameters must be specified within the RADTRAN code. These general parameters define basic characteristics of the shipment and traffic and are specific to the mode of transportation. The user's manual for the RADTRAN code (Neuhauser and Kanipe 1993) contains derivations and descriptions of these parameters. The general RADTRAN input parameters used in the transportation risk assessment are summarized in Table 6.5. 
TABLE 6.5 General RADTRAN Input Parameters

\begin{tabular}{lcc}
\multicolumn{1}{c}{ Parameter } & Truck & Rail \\
\hline & Type B Cask & Type B Cask \\
Package type & 2 & 5 \\
No. of crewmen & 3 & 152 \\
Distance from source to crew (m) & & \\
Average vehicle speed (km/h) & 88 & 64 \\
$\quad$ Rural & 40 & 40 \\
Suburban & 24 & 24 \\
$\quad$ Urban & 0.011 & 0.033 \\
Stop time (h/km) & 25 & 100 \\
No. of people exposed while stopped & 2 & 3 \\
No. of people per vehicle sharing route & & \\
Population densities (persons/km ${ }^{2}$ ) & 6 & 6 \\
$\quad$ Rural & 719 & 719 \\
Suburban & 3,861 & 3,861 \\
$\quad$ Urban & & \\
One-way traffic count (vehicles/h) & 470 & 1 \\
$\quad$ Rural & 780 & 5 \\
$\quad$ Suburban & 2,800 & 5 \\
$\quad$ Urban & $\mathrm{a}$ & $\mathrm{a}$ \\
Accident release fractions & $\mathrm{b}$ & $\mathrm{b}$ \\
Accident conditional probabilities & & \\
\hline
\end{tabular}

a See Table 6.4.

b See Table 6.3.

Source: Neuhauser and Kanipe (1993). 


\section{RESULTS OF RISK ASSESSMENT}

The results of the HLW transportation risk assessment are summarized in this section for each of the HLW alternatives. Detailed risk assessment results for each alternative are presented in the Appendix. The detailed results include per-shipment risk factors for each origin-destination pair considered by each case. The per-shipment risk factors presented in the Appendix can be used to estimate the risks for consolidation alternatives not explicitly considered in this report.

Although the method for risk assessment and important assumptions to be used for the assessment have been presented in detail in previous sections of this report, a brief overview of the risk assessment process is provided below to aid the reader in interpreting the risk assessment results.

The impacts of transportation are calculated in three areas: (1) collective population risks during routine conditions and accidents for each case, (2) risks to MEIs during routine conditions for each case, and (3) consequences to individuals and populations after the most severe accidents involving a release of radioactive material.

Collective Population Risk. The collective population risk is a measure of the total risk posed to society as a whole by the alternative being considered. For the collective population risk assessment, the persons exposed are considered as a group, without specifying individual receptors. The collective population risk is used as the primary means to compare the various alternatives.

Collective population risks are calculated from both vehicle- and cargo-related causes for routine transportation and accidents. Vehicle-related risks are independent of the cargo in the shipment and include risks from vehicular exhaust emissions and traffic accidents (fatalities caused by physical trauma). Vehicle-related risks are presented in terms of estimated fatalities for each alternative.

For radioactive material, cargo-related risk refers to the risk posed by the radioactive nature of the material. The collective population risks are calculated for each case by using RADTRAN 4. The RADTRAN 4 calculations for population risk take into account both the consequences and the probabilities of potential exposure-causing events (such as accidents). The accident risk values are referred to as "dose risk" because they incorporate the probabilities of a spectrum of accidents. The collective population risks are presented in terms of the total dose (person-rem) to workers and to members of the public for each case. The collective population risks are also presented in terms of estimated fatalities from latent cancer by using ICRP publication 60 health risk conversion factors (ICRP 1991). Other health end points, such as the incidence of cancer and severe genetic effects, are not explicitly presented but can be calculated by multiplying the total doses by the appropriate conversion factors given in Section 6.7. 
Maximally Exposed Individuals during Routine Conditions. During the routine transportation of radioactive waste, specific individuals may be exposed to radiation in the vicinity of a shipment. The risk to these individuals has been estimated for a number of hypothetical exposure-causing events by using RISKIND. The receptors include transportation crew members, inspectors, and members of the public exposed during traffic delays, working at a service station, or living near a DOE site. The assumptions about exposure are given in Section 6.8. The scenarios for exposure are not meant to be exhaustive but were selected to provide a range of potential exposures.

For the majority of the individual receptors considered, doses are assessed and presented on a per-event basis - no attempt is made to estimate the frequency of exposure-causing events, although the range of possible exposures is qualitatively discussed; however, one exception is the calculation of the dose to a hypothetical resident living near the entrance route to a storage or disposal site. For these residents, cumulative doses are calculated on the basis of the total number of shipments entering or exiting each site for each alternative.

Accident Consequence Assessment. The RISKIND code is used to provide a detailed assessment of the consequences of the most severe transportation-related accidents involving HLW shipments. Whereas the RADTRAN 4 collective accident risk assessment considers the entire range of accident severities and their related probabilities, the RISKIND accident consequence assessment assumes that an accident of the highest severity category (category VIII) has occurred. The consequences, in terms of committed dose (rem) and latent cancer fatalities, are calculated for both exposed populations and individuals in the vicinity of an accident.

\subsection{SHIPMENT SUMMARY}

In this report, the impacts of transportation have been calculated for shipment of the entire estimated inventory of HLW canisters to a repository; no annual estimates have been provided. However, shipments to a repository would likely take place over a period of approximately 25 years, so that annual risks can be estimated by dividing the total risks by a factor of 25 . Impacts have been calculated separately for all truck and all rail modes of shipment. For calculational purposes, the repository has been assumed to be located at the Yucca Mountain Site in Nevada.

The total number of shipments and mileage for loaded shipments for each alternative are summarized in Tables 7.1 and 7.2 for truck and rail shipments, respectively. In all cases, approximately 22,000 canisters of vitrified HLW ultimately would be shipped to a geologic repository for disposal. The total number of truck shipments, including shipments for purposes of interim storage, ranges from approximately 20,000 if all canisters except those from INEL are shipped directly to a repository (No Action Alternative) to about 28,000 if the canisters are consolidated at one site for interim storage (Centralized 2). For rail transportation, the corresponding 
TABLE 7.1 Summary of Total Population Impacts of HLW Transportation: Truck Mode

\begin{tabular}{|c|c|c|c|c|c|c|c|}
\hline \multirow{2}{*}{\multicolumn{2}{|c|}{ Parameter }} & \multicolumn{6}{|c|}{ Alternative $^{\mathfrak{a}}$} \\
\hline & & $\begin{array}{l}\text { No } \\
\text { Action }\end{array}$ & Decentralized & Regionalized 1 & Regionalized 2 & Centralized 1 & Centralized 2 \\
\hline \multicolumn{8}{|c|}{ Shipment summary } \\
\hline & Shipments & 19,912 & 21,612 & 21,952 & 21,952 & 24,325 & 28,224 \\
\hline & Mileage $\left(10^{6} \mathrm{mi}\right)$ & 29.4 & 30.7 & 31.0 & 31.2 & 34.6 & 39.5 \\
\hline \multicolumn{8}{|c|}{ Population impacts } \\
\hline \multicolumn{8}{|c|}{ Cargo-related ${ }^{\mathrm{b}}$} \\
\hline \multicolumn{8}{|c|}{ Dose risk (person-rem) } \\
\hline & Routine crew & 2,600 & 2,720 & 2,750 & 2,760 & 3,050 & 3,460 \\
\hline & Routine public & 3,520 & 3,670 & 3,710 & 3,730 & 4,120 & 4,690 \\
\hline & Accident ${ }^{c}$ & 0.68 & 0.684 & 0.680 & 0.688 & 0.725 & 0.760 \\
\hline \multicolumn{8}{|c|}{ Latent cancer fatalities ${ }^{d}$} \\
\hline & Crew fatalities & 1.0 & 1.1 & 1.1 & 1.1 & 1.2 & 1.4 \\
\hline & Public fatalities & 1.8 & 1.8 & 1.9 & 1.9 & 2.1 & 2.3 \\
\hline \multicolumn{8}{|c|}{ Vehicle-related $^{\mathrm{e}}$} \\
\hline & Emission fatalities & 0.21 & 0.23 & 0.23 & 0.23 & 0.25 & 0.27 \\
\hline & Accident fatalities & 1.8 & 1.9 & 1.9 & 1.9 & 2.1 & 2.3 \\
\hline & $\begin{array}{l}\text { Total population } \\
\text { health effects } \\
\text { (fatalities) }\end{array}$ & 4.8 & 5.0 & 5.1 & 5.1 & 5.7 & 6.3 \\
\hline \multicolumn{8}{|c|}{ Alternative definitions are summarized in Section 2.3 and provided in detail in Chapter 3 of the WM PEIS (DOE 1996). } \\
\hline \multicolumn{8}{|c|}{ b Cargo-related impacts are impacts attributable to the radioactive nature of the waste material. } \\
\hline \multicolumn{8}{|c|}{ ce. } \\
\hline \multicolumn{8}{|c|}{$\begin{array}{l}\text { Latent cancer fatalities are calculated by multiplying dose by the ICRP Publication } 60 \text { (ICRP 1991) health risk conversion factors of } \\
4 \times 10^{-4} \text { fatal cancers per person-rem for workers and } 5 \times 10^{-4} \text { for the public. }\end{array}$} \\
\hline \multicolumn{8}{|c|}{ Vehicle-related impacts are impacts independent of the shipment's cargo. } \\
\hline
\end{tabular}

numbers of shipments range from about 4,000 to 5,600 . The total mileage for loaded shipments ranges from about 47 to 64 million $\mathrm{km}$ ( 29.4 to 39.5 million mi) for truck transportation and from about 11 to 14 million $\mathrm{km}$ ( 6.7 to 8.7 million $\mathrm{mi}$ ) for rail transportation. The average annual mileage, estimated by dividing the total results by a shipping duration of 25 years, range from 1.9 to 2.5 million $\mathrm{km}$ (1.2 to 1.6 million mi) for truck, and 0.43 to 0.56 million $\mathrm{km}(0.27$ to 0.35 million $\mathrm{mi}$ ) for rail.

For purposes of comparison, the average annual reported distance for interstate truck shipments of all commodities within the United States was approximately 45.1 billion $\mathrm{km}$ ( 28 billion $\mathrm{mi}$ ) and for train shipments was approximately 48.8 billion railcar-km (30.3 billion 
TABLE 7.2 Summary of Total Population Impacts of HLW Transportation: Rail Mode

\begin{tabular}{|c|c|c|c|c|c|c|c|}
\hline \multirow{2}{*}{\multicolumn{2}{|c|}{ Parameter }} & \multicolumn{6}{|c|}{ Alternative $^{\mathfrak{a}}$} \\
\hline & & Action & Decentralized & Regionalized 1 & Regionalized 2 & Centralized 1 & Centralized 2 \\
\hline \multicolumn{8}{|c|}{ Shipment summary } \\
\hline & Shipments & 3,983 & 4,323 & 4,391 & 4,391 & 4,866 & 5,646 \\
\hline & Mileage $\left(10^{6} \mathrm{mi}\right)$ & 6.68 & 6.93 & 7.04 & 7.03 & 7.70 & 8.74 \\
\hline \multicolumn{8}{|c|}{ Population impacts } \\
\hline \multicolumn{8}{|c|}{ Cargo-related ${ }^{b}$} \\
\hline \multicolumn{8}{|c|}{ Dose risk (person-rem) } \\
\hline & Routine crew & 153 & 161 & 163 & 163 & 180 & 205 \\
\hline & Routine public & 168 & 175 & 178 & 177 & 192 & 215 \\
\hline & Accident $^{c}$ & 0.0215 & 0.0215 & 0.0208 & 0.0217 & 0.0234 & 0.0250 \\
\hline \multicolumn{8}{|c|}{ Latent cancer fatalities ${ }^{d}$} \\
\hline & Crew fatalities & 0.061 & 0.064 & 0.065 & 0.065 & 0.072 & 0.082 \\
\hline & Public fatalities & 0.084 & 0.088 & 0.089 & 0.089 & 0.096 & 0.11 \\
\hline \multicolumn{8}{|c|}{ Vehicle-related $^{e}$} \\
\hline & Emission fatalities & 0.041 & 0.043 & 0.043 & 0.043 & 0.046 & 0.050 \\
\hline & Accident fatalities & 0.014 & 0.015 & 0.015 & 0.015 & 0.016 & 0.018 \\
\hline & $\begin{array}{l}\text { Total population } \\
\text { health effects } \\
\text { (fatalities) }\end{array}$ & 0.20 & 0.21 & 0.21 & 0.21 & 0.23 & 0.26 \\
\hline \multicolumn{8}{|c|}{ a Alternative definitions are summarized in Section 2.3 and provided in detail in Chapter 3 of the WM PEIS (DOE 1996). } \\
\hline \multicolumn{8}{|c|}{ cts attributable to the rad } \\
\hline \multicolumn{8}{|c|}{ Dose risk is a societal risk } \\
\hline d & \multicolumn{7}{|c|}{$\begin{array}{l}\text { Latent cancer fatalities are calculated by multiplying dose by the ICRP Publication } 60 \text { (ICRP 1991) health risk conversion factors of } \\
4 \times 10^{-4} \text { fatal cancers per person-rem for workers, and } 5 \times 10^{-4} \text { for the public. }\end{array}$} \\
\hline
\end{tabular}

railcar-mi) for the years 1986-1988 (Saricks and Kvitek 1994). The annual HLW shipments would thus represent less than $0.006 \%$ of the annual amount of truck and rail transportation activity within the United States for all alternatives.

\subsection{COLLECTIVE POPULATION RISK}

The results for the collective risk assessment for HLW shipments are also summarized in Tables 7.1 and 7.2 for truck and rail shipments, respectively. The collective risk results are presented for shipment of the total estimated inventory of HLW canisters; no annual risk estimates have been included. The average annual risk of HLW shipments can be estimated by dividing the results by a shipping duration of 25 years. 
Examination of the results of the transportation risk assessment shows that differences in population risk among the various alternatives are dependent primarily on total shipping distances. The total shipping distance for each alternative is determined by the definition of the alternative (shipment origin and destination sites), site-specific waste inventories (specifically canister inventories, which directly determine the total number of shipments), and the route distances among all pairs of origin and destination sites.

For truck transportation, the total estimated number of fatalities from radiological causes ranges from approximately 2.8 to 3.7 . For rail transportation, the number of fatalities from radiological causes ranges from 0.15 to 0.19 . In general, shipment by the rail mode results in lower doses to crew members and the public, primarily because of the reduced number of shipments involved. The vehicle- and cargo-related risks are comparable for truck shipments. The vehiclerelated risks are generally greater than the cargo-related risks for rail transportation.

Detailed collective risk results are presented in the Appendix for each alternative. The detailed results include per-shipment risk factors for both vehicle-related and cargo-related causes for each origin-destination pair defined by the alternative. The detailed results also include a breakdown of the total radiation dose by route and express total risks for each case in terms of cancer fatalities, cancer incidence, and genetic effects.

\subsection{MAXIMALLY EXPOSED INDIVIDUALS}

The estimated doses during routine transportation for each of the individual receptors considered (see Section 6.8 for exposure assumptions) are presented in Table 7.3 on a per-event basis. Also included in Table 7.3 are the estimates of lifetime risk of fatal cancer for each scenario based on the estimated dose for that receptor and the health risk conversion factors described in Section 6.8. The total dose or risk for repeated exposures can be estimated by multiplying the perevent dose by the number of exposure-causing events.

The potential exists for significant individual exposures if multiple exposure-causing events occur; for instance, the dose to a person stopped in traffic next to a HLW shipment for 30 minutes is estimated to be $11 \mathrm{mrem}$. If the duration of exposure were longer, the dose would rise proportionally. Therefore, conceivably, a person could receive a dose on the order of $30-50 \mathrm{mrem}$ while stopped in traffic next to a HLW shipment (a person would have to remain at a distance of $1 \mathrm{~m}$ from the cask transporter for a period of 3-5 hours, an unlikely, but possible, scenario). In addition, a person working at a truck service station could receive an increased dose if trucks use the same stops repeatedly. If a truck-stop worker is present for 100 shipment stops (at the distance and duration given previously), the calculated dose is on the order of $30 \mathrm{mrem}$. Administrative controls could be instituted to control the location and duration of truck stops if multiple exposures were to happen routinely. 
TABLE 7.3 Estimated Routine Doses and Lifetime Risk of Fatal Cancer to MEIs from Shipments of HLW (per exposure event) ${ }^{a}$

\begin{tabular}{|c|c|c|c|c|}
\hline \multirow[b]{2}{*}{ Receptor $^{b}$} & \multicolumn{2}{|c|}{ Dose (rem) } & \multicolumn{2}{|c|}{ Lifetime Risk ${ }^{\mathfrak{c}}$} \\
\hline & Truck & Rail & Truck & Rail \\
\hline \multicolumn{5}{|l|}{ Workers } \\
\hline Crew member & $d$ & $d$ & $\mathrm{~d}$ & $\mathrm{~d}$ \\
\hline Inspector & $2.9 E-03$ & $2.9 \mathrm{E}-03$ & $1 \mathrm{E}-06$ & $1 E-06$ \\
\hline Rail-yard crew member & $\mathrm{NA}^{\mathrm{e}}$ & $1.3 \mathrm{E}-03$ & $\mathrm{NA}^{\mathrm{e}}$ & $5 \mathrm{E}-07$ \\
\hline \multicolumn{5}{|l|}{ Public } \\
\hline Resident & $4.0 \mathrm{E}-07$ & $4.0 \mathrm{E}-07$ & $2 \mathrm{E}-10$ & $2 E-10$ \\
\hline Person in traffic jam & $1.1 \mathrm{E}-02$ & $1.1 \mathrm{E}-02$ & $6 \mathrm{E}-06$ & $6 \mathrm{E}-06$ \\
\hline Person at service station & $3.1 E-04$ & $\mathrm{NA}^{\mathrm{e}}$ & $2 \mathrm{E}-07$ & $\mathrm{NA}^{\mathrm{e}}$ \\
\hline Resident near rail stop & $\mathrm{NA}^{\mathrm{e}}$ & $1.3 E-05$ & $\mathrm{NA}^{\mathrm{e}}$ & $7 \mathrm{E}-09$ \\
\hline \multicolumn{5}{|c|}{$\begin{array}{l}\text { The external dose rate is assumed to be } 10 \mathrm{mrem} / \mathrm{h} \text { at } 2 \mathrm{~m}(6.6 \mathrm{ft}) \text { for all } \\
\text { shipments. }\end{array}$} \\
\hline \multicolumn{5}{|c|}{ b Receptor assumptions are described in Section 6.8.} \\
\hline \multicolumn{5}{|c|}{$\begin{array}{l}\text { Lifetime risk of fatal cancer based on ICRP publication } 60 \text { health risk } \\
\text { conversion factors of } 4 \times 10^{-4} \text { and } 5 \times 10^{-4} \text { fatal cancers per person-rem for } \\
\text { workers and members of the public, respectively (ICRP 1991). }\end{array}$} \\
\hline \multicolumn{5}{|c|}{$\begin{array}{l}\text { The DOE administrative control level limits doses to DOE workers to } \\
2 \mathrm{rem} / \mathrm{yr} \text {. For a representative shipment of } 1,600 \mathrm{~km}(1,000 \mathrm{mi}) \text { and an } \\
\text { average speed of } 80 \mathrm{~km} / \mathrm{h}(50 \mathrm{mph}) \text {, the dose to a driver would be } \\
\text { approximately } 40 \mathrm{mrem} \text { if the dose rate in the crew compartment were at the } \\
\text { regulatory limit of } 2 \mathrm{mrem} / \mathrm{h} \text {. Dose rates are typically much less than } \\
2 \mathrm{mrem} / \mathrm{h} \text { in the crew compartment. }\end{array}$} \\
\hline e $\mathrm{NA}=$ not applicable. & & & & \\
\hline
\end{tabular}

It is possible that a resident living near a site entrance road may be exposed to multiple shipments as HLW shipments enter or exit a site. The potential cumulative dose to a resident living along a site entrance route is summarized in Table 7.4 for each alternative. The cumulative doses assume that a resident is present for every shipment entering or exiting a site and is unshielded at a distance of $30 \mathrm{~m}$ ( $98 \mathrm{ft}$ ) from the entrance route. The maximum cumulative dose would occur near the Hanford site in the Centralized 2 alternative because of the large number of shipments entering and leaving the site. The maximum dose to this resident would be approximately $11 \mathrm{mrem}$ for the $100 \%$ truck case and 2 mrem for the $100 \%$ rail case. The annual dose can be estimated by assuming that shipments would occur over a 25 -year period. The estimated dose to a resident would be well below the annual limit of 100 mrem specified for members of the public (DOE 1990b). 
TABLE 7.4 Cumulative Estimated Routine Dose and Lifetime Risk to a Resident Living along a Site Entrance Route ${ }^{\mathbf{a}}$

\begin{tabular}{|c|c|c|c|c|c|c|}
\hline \multirow[b]{2}{*}{$\begin{array}{c}\text { Alternative/ } \\
\text { Site } \\
\end{array}$} & \multicolumn{3}{|c|}{ All Truck } & \multicolumn{3}{|c|}{ All Rail } \\
\hline & $\begin{array}{c}\text { Total } \\
\text { Shipments }\end{array}$ & $\begin{array}{l}\text { Dose } \\
\text { (rem) }\end{array}$ & $\begin{array}{c}\text { Lifetime } \\
\text { Risk }^{b}\end{array}$ & $\begin{array}{c}\text { Total } \\
\text { Shipments }\end{array}$ & $\begin{array}{l}\text { Dose } \\
\text { (rem) }\end{array}$ & $\begin{array}{c}\text { Lifetime } \\
\text { Risk }^{\mathrm{b}}\end{array}$ \\
\hline \multicolumn{7}{|l|}{ No Action } \\
\hline Repository & 19,912 & $8.0 \mathrm{E}-03$ & 4.E-06 & 3,983 & $1.6 \mathrm{E}-03$ & $8 \mathrm{E}-07$ \\
\hline Hanford & 15,000 & $6.0 \mathrm{E}-03$ & $3 E-06$ & 3,000 & $1.2 \mathrm{E}-03$ & $6 E-07$ \\
\hline SRS & 4,572 & $1.8 \mathrm{E}-03$ & $9 \mathrm{E}-07$ & 915 & $3.7 \mathrm{E}-04$ & $2 E-07$ \\
\hline WVDP & 340 & $1.4 \mathrm{E}-04$ & $7 \mathrm{E}-08$ & 68 & $2.7 \mathrm{E}-05$ & $1 \mathrm{E}-08$ \\
\hline INEL & 0 & $0.0 \mathrm{E}+00$ & $0 \mathrm{E}+00$ & 0 & $0.0 \mathrm{E}+00$ & $0 \mathrm{E}+00$ \\
\hline \multicolumn{7}{|l|}{ Decentralized } \\
\hline Repository & 21,612 & $8.6 \mathrm{E}-03$ & $4 E-06$ & 4,323 & $1.7 \mathrm{E}-03$ & $9 E-07$ \\
\hline Hanford & 15,000 & $6.0 \mathrm{E}-03$ & $3 E-06$ & 3,000 & $1.2 \mathrm{E}-03$ & $6 \mathrm{E}-07$ \\
\hline SRS & 4,572 & $1.8 \mathrm{E}-03$ & $9 \mathrm{E}-06$ & 915 & $3.7 \mathrm{E}-04$ & $2 E-07$ \\
\hline INEL & 1,700 & $6.8 \mathrm{E}-04$ & $3 \mathrm{E}-07$ & 340 & $1.4 \mathrm{E}-04$ & $7 \mathrm{E}-08$ \\
\hline WVDP & 340 & $1.4 \mathrm{E}-04$ & $7 E-08$ & 68 & $2.7 \mathrm{E}-05$ & $1 E-08$ \\
\hline \multicolumn{7}{|l|}{ Regionalized 1} \\
\hline Repository & 21,612 & $8.6 \mathrm{E}-03$ & $4 \mathrm{E}-06$ & 4,323 & $1.7 \mathrm{E}-03$ & $9 E-07$ \\
\hline Hanford & 15,000 & $6.0 \mathrm{E}-03$ & $3 E-06$ & 3,000 & $1.2 \mathrm{E}-03$ & $6 \mathrm{E}-07$ \\
\hline SRS & 5,252 & $2.1 \mathrm{E}-03$ & $1 E-06$ & 1,051 & $4.2 \mathrm{E}-04$ & $2 \mathrm{E}-07$ \\
\hline INEL & 1,700 & $6.8 \mathrm{E}-04$ & $3 E-07$ & 340 & $1.4 \mathrm{E}-04$ & $7 \mathrm{E}-08$ \\
\hline WVDP & 340 & $1.4 \mathrm{E}-04$ & $7 E-08$ & 68 & $2.7 \mathrm{E}-05$ & $1 \mathrm{E}-08$ \\
\hline \multicolumn{7}{|l|}{ Regionalized 2} \\
\hline Repository & 21,612 & $8.6 \mathrm{E}-03$ & $4 \mathrm{E}-06$ & 4,323 & $1.7 \mathrm{E}-03$ & $9 E-07$ \\
\hline Hanford & 15,680 & $6.3 \mathrm{E}-03$ & $3 E-06$ & 3,136 & $1.3 \mathrm{E}-03$ & $6 \mathrm{E}-07$ \\
\hline SRS & 4,572 & $1.8 \mathrm{E}-03$ & $9 \mathrm{E}-07$ & 915 & $3.7 \mathrm{E}-04$ & $2 \mathrm{E}-07$ \\
\hline INEL & 1,700 & $6.8 \mathrm{E}-04$ & $3 E-07$ & 340 & $1.4 \mathrm{E}-04$ & $7 E-08$ \\
\hline WVDP & 340 & $1.4 \mathrm{E}-04$ & 7E-08 & 68 & 2.7E-05 & $1 \mathrm{E}-08$ \\
\hline \multicolumn{7}{|l|}{ Centralized 1} \\
\hline Repository & 21,612 & $8.6 \mathrm{E}-03$ & $4 \mathrm{E}-06$ & 4,323 & $1.7 \mathrm{E}-03$ & $9 \mathrm{E}-07$ \\
\hline Hanford & 20,426 & $8.2 E-03$ & $4 \mathrm{E}-06$ & 4,086 & $1.6 \mathrm{E}-03$ & $8 E-07$ \\
\hline SRS & 4,572 & $1.8 \mathrm{E}-03$ & $9 \mathrm{E}-07$ & 915 & $3.7 \mathrm{E}-04$ & $2 \mathrm{E}-07$ \\
\hline INEL & 1,700 & $6.8 \mathrm{E}-04$ & $3 E-07$ & 340 & $1.4 \mathrm{E}-04$ & $7 E-08$ \\
\hline WVDP & 340 & $1.4 \mathrm{E}-04$ & $7 E-08$ & 68 & $2.7 \mathrm{E}-05$ & $1 \mathrm{E}-08$ \\
\hline \multicolumn{7}{|l|}{ Centralized 2} \\
\hline Hanford & 28,224 & $1.1 \mathrm{E}-02$ & $6 \mathrm{E}-06$ & 5,646 & $2.3 E-03$ & $1 \mathrm{E}-06$ \\
\hline Repository & 21,612 & $8.6 \mathrm{E}-03$ & $4 E-06$ & 4,323 & $1.7 \mathrm{E}-03$ & $9 \mathrm{E}-07$ \\
\hline SRS & 4,572 & $1.8 \mathrm{E}-03$ & $9 \mathrm{E}-07$ & 915 & $3.7 \mathrm{E}-04$ & $2 \mathrm{E}-07$ \\
\hline INEL & 1,700 & $6.8 E-04$ & $3 \mathrm{E}-07$ & 340 & $1.4 \mathrm{E}-04$ & $7 \mathrm{E}-08$ \\
\hline WVDP & 340 & $1.4 \mathrm{E}-04$ & $7 \mathrm{E}-08$ & 68 & 2.7E-05 & $1 \mathrm{E}-08$ \\
\hline $\begin{array}{l}\text { The externa } \\
\text { present for } \\
\text { of } 30 \mathrm{~m} \text { ( } 98\end{array}$ & $\begin{array}{l}\text { rate is assu } \\
\text { ments that } \\
\text { an averag }\end{array}$ & $\begin{array}{l}\text { to be } 10 \\
\text { er enter } \\
\text { eed of } 2\end{array}$ & $\begin{array}{l}\mathrm{m} / \mathrm{h} \text { at } 2 \\
\mathrm{t} \text { the site. } \\
\mathrm{h}(15 \mathrm{mp}\end{array}$ & $\begin{array}{l}\text { The resid } \\
\text { ts are assu }\end{array}$ & $\begin{array}{l}\text { assumed } \\
\text { to pass at }\end{array}$ & $\begin{array}{l}\text { be } \\
\text { listance }\end{array}$ \\
\hline $\begin{array}{l}\text { Lifetime ris } \\
\text { of } 4 \times 10^{-4} \mathrm{fa}\end{array}$ & $\begin{array}{l}\text { al cancer } b \\
\text { cers per pe }\end{array}$ & on ICR & lication & $\begin{array}{l}\text { 1991) her } \\
\text { the publi }\end{array}$ & sk conv & factors \\
\hline
\end{tabular}


Note that the estimated doses presented above are highly dependent upon the external cask dose rates and the specific exposure assumptions selected for each scenario. The assessment assumes that the external dose rate is at the maximum regulatory limit and therefore represents a conservative estimate in that dose rates cannot exceed this value. However, the exposure distances and durations are subjective in nature. As stated above, the scenarios were selected only to represent reasonable exposure situations that are foreseeable.

\subsection{ACCIDENT CONSEQUENCE}

The results of the accident consequence assessment for HLW are presented in Table 7.5. As stated previously, the results are calculated for transportation-related accidents that result in the maximum release of radioactive material. The results were calculated for SRS HLW, which was found to result in the highest accident doses of the four types of site-specific HLW. (However, the maximum accident doses for the four HLW types were all within a factor of 5.) The population doses are for a uniform population density within an $80-\mathrm{km}(50-\mathrm{mi})$ radius of accidents occurring in rural, suburban, and urban population zones.

The location of the MEI after an accident is determined on the basis of atmospheric conditions and the buoyant characteristics of the released plume. The locations of maximum exposure are $160 \mathrm{~m}(525 \mathrm{ft})$ and $400 \mathrm{~m}(1,312 \mathrm{ft})$ from the accident site for neutral and stable conditions, respectively. The dose to the MEI is independent of the location of the accident. The maximum dose to an individual is approximately 60 mrem under unfavorable weather conditions, which corresponds to a lifetime fatal cancer risk of $3 \times 10^{-5}$. 
TABLE 7.5 Estimated Consequences for the Most Severe Accidents Involving Shipments of HLW $\mathrm{W}^{\mathrm{a}, \mathrm{b}}$

\begin{tabular}{|c|c|c|c|c|c|c|c|c|}
\hline \multirow[b]{3}{*}{$\begin{array}{c}\text { Mode/ } \\
\text { Accident } \\
\text { Location }\end{array}$} & \multicolumn{4}{|c|}{ Neutral Conditions ${ }^{c}$} & \multicolumn{4}{|c|}{ Stable Conditions $^{d}$} \\
\hline & \multicolumn{2}{|c|}{ Population $^{\mathrm{e}}$} & \multicolumn{2}{|c|}{$\mathrm{MEI}^{\mathrm{f}}$} & \multicolumn{2}{|c|}{ Population $^{\mathrm{e}}$} & \multicolumn{2}{|c|}{$\mathrm{MEl}^{\mathrm{f}}$} \\
\hline & $\begin{array}{c}\text { Dose } \\
\text { (person-rem) }\end{array}$ & $\begin{array}{c}\text { Risk } \\
\text { (cancer } \\
\text { fatalities) }\end{array}$ & $\begin{array}{l}\text { Dose } \\
\text { (rem) }\end{array}$ & $\begin{array}{c}\text { Risk } \\
\text { (cancer } \\
\text { fatality) }\end{array}$ & $\begin{array}{c}\text { Dose } \\
\text { (person-rem) }\end{array}$ & $\begin{array}{c}\text { Risk } \\
\text { (cancer } \\
\text { fatalities) }\end{array}$ & $\begin{array}{l}\text { Dose } \\
\text { (rem) }\end{array}$ & $\begin{array}{c}\text { Risk } \\
\text { (cancer } \\
\text { fatality) }\end{array}$ \\
\hline \multicolumn{9}{|l|}{ Truck } \\
\hline Urban & $4.2 \mathrm{E}+00$ & $2 \mathrm{E}-03$ & $3.4 \mathrm{E}-03$ & $1.7 \mathrm{E}-06$ & $3.4 \mathrm{E}+01$ & $1.7 \mathrm{E}-02$ & $1.2 \mathrm{E}-02$ & $6 \mathrm{E}-06$ \\
\hline Suburban & $7.8 \mathrm{E}-01$ & $4 E-04$ & $3.4 \mathrm{E}-03$ & $1.7 \mathrm{E}-06$ & $6.2 \mathrm{E}+00$ & $3.1 \mathrm{E}-03$ & $1.2 \mathrm{E}-02$ & $6 \mathrm{E}-06$ \\
\hline Rural & $1.6 \mathrm{E}-02$ & $8 E-06$ & $3.4 \mathrm{E}-03$ & $1.7 \mathrm{E}-06$ & $1.3 \mathrm{E}-01$ & $6.5 E-05$ & $1.2 \mathrm{E}-02$ & $6 E-06$ \\
\hline \multicolumn{9}{|l|}{ Rail } \\
\hline Urban & $2.1 \mathrm{E}+01$ & $1 E-02$ & $1.7 \mathrm{E}-02$ & $8.5 \mathrm{E}-06$ & $1.7 \mathrm{E}+02$ & $8.5 \mathrm{E}-02$ & $6 \mathrm{E}-02$ & $3 E-05$ \\
\hline Suburban & $3.9 \mathrm{E}+00$ & $2 \mathrm{E}-03$ & $1.7 \mathrm{E}-02$ & $8.5 E-06$ & $3.1 \mathrm{E}+01$ & $1.6 \mathrm{E}-02$ & $6 \mathrm{E}-02$ & $3 E-05$ \\
\hline Rural & $8.0 \mathrm{E}-02$ & $4 E-05$ & $1.7 \mathrm{E}-02$ & $8.5 \mathrm{E}-06$ & $6.5 \mathrm{E}-01$ & $3.3 \mathrm{E}-04$ & $6 \mathrm{E}-02$ & $3 E-05$ \\
\hline
\end{tabular}

a The most severe accidents correspond to the highest NUREG-0170 accident severity category (category VIII) (NRC 1977a). Results are presented for HLW from SRS.

b Buoyant plume rise resulting from fire for a severe accident was included in the exposure model. One HLW canister is assumed to be breached in a truck accident; five canisters are assumed to be equally breached in a rail accident

c Neutral weather conditions result in moderate dispersion and dilution of the released plume. Neutral conditions were taken to be Pasquill stability Class D with a wind speed of $4 \mathrm{~m} / \mathrm{s}(9 \mathrm{mph})$. Neutral conditions occur approximately $50 \%$ of the time in the United States.

d Stable weather conditions result in minimal dispersion and dilution of the released plume and are thus unfavorable. Stable conditions were taken to be Pasquill stability Class F with a wind speed of $1 \mathrm{~m} / \mathrm{s}(2.2 \mathrm{mph})$. Stable conditions occur approximately one third of the time in the United States.

e Populations extend at a uniform population density to a radius of $80 \mathrm{~km}(50 \mathrm{mi})$ from the accident site. Population exposure pathways include acute inhalation; acute cloudshine; groundshine; resuspended inhalation; resuspended cloudshine; and ingestion of food, including initially contaminated food (rural only). No decontamination or mitigative actions are taken.

f The MEI is assumed to be at the location of maximum exposure. The locations of maximum exposure would be $160 \mathrm{~m} \mathrm{(} 525 \mathrm{ft}$ ) and $400 \mathrm{~m}$ $(1,312 \mathrm{ft})$ from the accident site under neutral and stable atmospheric conditions, respectively. Individual exposure pathways include acute inhalation, acute cloudshine, and groundshine during passage of the plume. No ingested dose is considered. 


\section{UNCERTAINTIES AND CONSERVATISM IN ESTIMATED IMPACTS}

The sequence of analyses performed to generate the estimates of radiological risk for the transportation of HLW includes (1) determination of the waste inventory and characteristics at each site, (2) estimation of shipment requirements, (3) determination of route characteristics, (4) calculation of radiation doses to exposed individuals (including estimation of environmental transport and uptake of radionuclides), and (5) estimation of health effects. Uncertainties are associated with each of these steps. Uncertainties exist in the way that the physical systems being analyzed are represented by the computational models, in the data required to exercise the models (due to measurement errors, sampling errors, natural variability, or unknowns simply caused by the future nature of the actions being analyzed), and in the calculations themselves (for example, approximate algorithms used by the computers).

In principle, one can estimate the uncertainty associated with each input or computational source and predict the resultant uncertainty in each set of calculations. Thus, one can propagate the uncertainties from one set of calculations to the next and estimate the uncertainty in the final, or absolute, result; however, conducting such a full-scale quantitative uncertainty analysis is often impractical and sometimes impossible, especially for actions to be initiated at an unspecified time in the future. Instead, the risk analysis is designed to ensure - through uniform and judicious selection of scenarios, models, and input parameters - that relative comparisons of risk among the various alternatives are meaningful. In the transportation risk assessment, this design is accomplished by uniformly applying common input parameters and assumptions to each alternative. Therefore, although considerable uncertainty is inherent in the absolute magnitude of the transportation risk for each alternative, much less uncertainty is associated with the relative differences among the alternatives in a given measure of risk.

In the following sections, areas of uncertainty are discussed for each of the assessment steps enumerated above. Special emphasis is placed on identifying whether the uncertainties affect relative or absolute measures of risk. Where practical, the parameters that most significantly affect the risk assessment results are identified, and quantitative estimates of uncertainty are provided.

\subsection{UNCERTAINTIES IN WASTE INVENTORY AND CHARACTERIZATION}

The site-specific HLW inventories (i.e., number of canisters) and the physical and radiological waste characteristics are important input parameters to the transportation risk assessment. The potential amount of transportation for any alternative is determined primarily by the projected waste inventory at each site and assumptions concerning shipment capacities. The physical and radiological waste characteristics are important in determining the amount of waste 
released during accidents and the subsequent doses to exposed individuals through multiple environmental exposure pathways.

The development of projected site-specific HLW inventory and waste characterization data used to support the WM PEIS is described in a technical report (Folga et al. 1996). The technical report also contains detailed information on current and projected HLW management activities at each of the four HLW sites and identifies uncertainties in the data used for assessment purposes. In general, the uncertainties in the data are site-specific, could affect both relative and absolute measures of transportation risk, and are difficult to quantify. The number of canisters to be produced at WVDP is relatively well defined; however, the canister estimates for the other three sites are highly uncertain. The final waste form has not been decided for HLW stored as calcine at INEL; the process selected for assessment purposes represents a best estimate at this time. In addition, considerable uncertainty exists for treatment of HLW at Hanford.

Precisely defining the impact of these uncertainties on the transportation risk analysis is difficult because of the number of sites and alternatives and the inability to accurately quantify the waste characterization uncertainty at each site. The uncertainties in the waste characterization data will be reflected to some degree in the transportation risk results. If the waste inventories are consistently overestimated (or underestimated), the resulting transportation risk estimates also will be overestimated (or underestimated) by roughly the same factor. In terms of relative risk comparisons, if the uncertainty in one site inventory is larger than in other site inventories, then the uncertainties may not be comparable among different consolidation alternatives, and meaningful relative risk comparisons will be difficult. For instance, if the inventory at site $\mathrm{A}$ is overestimated compared with other sites, the risk assessment results will be unduly biased toward alternatives that do not involve shipment of site A waste. In this assessment, however, the waste characterization data have been carefully developed by uniformly applying consistent methodologies and assumptions to the best available information. This approach is expected to limit the overall uncertainty in the data and the likelihood that the level of uncertainty will vary significantly among sites. For comparative purposes, the observed differences in transportation risks among alternatives are believed to represent unbiased, reasonably accurate estimates from current information.

\subsection{UNCERTAINTIES IN SHIPMENT CAPACITIES}

As stated above, the amount of transportation required for each alternative is based in part on assumptions concerning the packaging characteristics and shipment capacities for truck and rail modes. Representative shipment capacities have been defined for each mode based on probable future shipment capacities-truck and rail casks were assumed to accept one and five canisters, respectively. In reality, the actual shipment capacities may differ from the predicted capacities, so that the projected number of shipments, and consequently the total transportation risk, would change. However, although the predicted transportation risks would increase or decrease accordingly, the 
relative differences in risks among consolidation alternatives would remain about the same. It is in fact likely that DOE would deploy a multi-canister truck cask for large shipping campaigns; assuming a single-canister cask would therefore provide a conservative estimate of risk for truck shipments.

\subsection{UNCERTAINTIES IN ROUTE DETERMINATION}

Representative routes have been determined between all origin and destination sites considered by the alternatives. The routes have been determined consistent with current guidelines, regulations, and practices but may not be the actual routes that will be used in the future. In reality, the actual routes may differ from the representative ones in terms of distances and total population along the routes. Moreover, in that the assessment considers HLW that may be transported over a period of 20-30 years starting at some time in the future, the highway and rail infrastructures and the demographics along routes may change. These effects have not been accounted for in the transportation assessment; however, it is not anticipated that these changes would significantly affect relative comparisons of risk among the alternatives considered in the WM PEIS.

\subsection{UNCERTAINTIES IN CALCULATION OF RADIATION DOSES}

The models used to calculate radiation doses from transportation activities introduce a further uncertainty in the risk assessment process. It is generally difficult to estimate the accuracy, or absolute uncertainty, of the risk assessment results. The accuracy of the calculated results is closely related to the limitations of the computational models and to the uncertainties in each of the input parameters that the model requires. The single greatest limitation facing users of RADTRAN, or any computer code of this type, is the scarcity of data for certain input parameters.

Uncertainties associated with the computational models are minimized by using state-of-the-art computer codes that have undergone extensive review. Because there are numerous uncertainties that are recognized but difficult to quantify, assumptions are made at each step of the risk assessment process that are intended to produce conservative results (i.e., overestimate the calculated dose and radiological risk). Because parameters and assumptions are applied equally to all alternatives, this model bias is not expected to affect the meaningfulness of relative comparisons of risk; however, the results may not represent risks in an absolute sense.

In order to understand the most important uncertainties and areas of conservatism in the transportation risk assessment, the results for all alternatives were examined to identify the largest contributors to the collective population risk. The results of this examination are discussed briefly below. 
For truck shipments, the largest contributors to the collective population dose were found to be, in decreasing order of importance, (1) incident-free dose to members of the public at stops, (2) incident-free dose to transportation crew members, (3) incident-free dose to members of the public sharing the route (on-link dose), (4) incident-free dose to members of the public residing along the route (off-link dose), and (5) accident dose risk to members of the public. Approximately $80 \%$ of the estimated public dose was incurred at stops, $15 \%$ by the on-link population, and $5 \%$ by the off-link population. In general, the accident contribution to the total risk was negligible compared with the incident-free risk.

For rail shipments, the largest contributors to the collective population dose were found to be, in decreasing order of importance, (1) incident-free dose to transportation crew members, (2) incident-free dose to members of the public residing along the route (off-link dose), (3) incident-free dose to members of the public at stops, (4) incident-free dose to members of the public sharing the route (on-link dose), and (5) accident dose risk to members of the public. Approximately $70 \%$ of the estimated public dose was incurred by the off-link population, $25 \%$ by the population at stops, and $5 \%$ by the on-link population. As with truck shipments, the accident contribution to the total risk in general was negligible compared with the incident-free risk.

As shown above, incident-free transportation risks are the dominant component of the total transportation risk for both truck and rail modes. The most important parameter in calculating incident-free doses is the shipment external dose rate (incident-free doses are directly proportional to the shipment external dose rate). For this assessment, it was assumed that all HLW shipments would have an external dose rate at the regulatory maximum of $10 \mathrm{mrem} / \mathrm{h}$ at $2 \mathrm{~m}$ from the shipment. In practice, the external dose rates will not only vary from site to site, but also from shipment to shipment at a given site; and the rates will range well below the limit assumed for this assessment (dose rates cannot exceed the regulatory maximum). Therefore, the assessment provides a conservative estimate of incident-free impacts.

Finally, the single largest contributor to the collective population doses calculated with RADTRAN was found to be the dose to members of the public at truck stops. Currently, RADTRAN uses a simple point-source approximation for truck-stop exposures and assumes that the total stop time for a shipment is proportional to the shipment distance. The parameters used in the stop model were based on a survey of a very limited number of radioactive material shipments that examined a variety of shipment types in different areas of the country (Madsen and Wilmot 1983). It was assumed that stops occur as a function of distance, with a stop rate of $0.011 \mathrm{~h} / \mathrm{km}$. It was further assumed that at each stop, an average of 25 people are exposed at a distance of $20 \mathrm{~m}$. The population dose is directly proportional to the external shipment dose rate and the number of people exposed and inversely proportional to the square of the distance. Based upon the limited data available, the parameter values used in the assessment appear to be conservative; however, data do not exist to qualitatively assess the degree of conservatism in the stop-dose model. As a practical matter, it is 
conceivable that DOE could take steps to control the location, frequency, and duration of truck stops if necessary to reduce excessive exposure to radiation.

\subsection{UNCERTAINTIES IN COMPARISON OF TRUCK AND RAIL TRANSPORTATION MODES}

The HLW transportation risk assessment results presented in the WM PEIS indicate that rail transportation poses a lower overall risk to workers and the public as compared with truck transportation of the same quantity of waste. However, it is important to recognize that although rail shipments were found to result in a smaller number of expected fatalities compared with truck shipments, in general the risks from transportation operations are small for both modes. Moreover, comparisons between truck and rail shipment risks need to consider the uncertainties inherent in the risk assessment process. As discussed above, in most cases the calculational uncertainties are difficult to quantify and, in fact, may not be the same between the truck and rail assessment assumptions. 


\section{MITIGATIVE MEASURES}

The DOE is committed to conducting all transportation-related activities in a manner protective of human health and safety. The hazards of transporting radioactive materials under both incident-free and accident conditions are minimized by existing packaging and shipment regulations, as summarized in Section 3. All activities related to the transportation of HLW would be conducted in accordance with the applicable health and safety requirements of the federal government, states, and local jurisdictions, including requirements promulgated by DOT in Title 49 of the Code of Federal Regulations.

Although detailed plans concerning HLW transportation will not be prepared for major shipping campaigns until some time in the future, safety plans have been prepared for a transportation program involving the transportation of transuranic waste to the DOE Waste Isolation Pilot Plant (WIPP), which is a mined geologic repository. The plans for the WIPP can be considered to be representative of those for future major DOE programs for waste transportation. Provisions in the WIPP plans (DOE 1990a) include the following mechanisms and measures:

- Provision of vehicles and equipment with the best available mechanical safeguards, including governors that limit speed and personal protective equipment;

- Provision of a facility for maintenance and inspection of equipment;

- Implementation of a safety program, including personnel training in safe work practices;

- Stringent driver-training program and penalty provisions;

- Accident and emergency training;

- Provision of constant-surveillance service for all loaded shipments; and

- Provision of communications equipment and services.

In reviewing the WIPP program activities, the National Academy of Sciences concluded that the "system proposed for transportation of TRUW waste to WIPP is safer than that employed for any other hazardous material in the United States today and will reduce risk to very low levels" (DOE 1990a). 
In addition to these policies, DOE may impose administrative measures to control accumulated doses in specific circumstances. Examples of administrative controls would include requiring temporary lead shielding between loaded casks and service personnel, controlling the location and duration of service stops, and prohibiting transportation during inclement weather. These measures would act to ensure that all exposures are maintained below the regulatory dose limits specified in DOE Orders 5400.5 and 5480.11 (DOE 1988c, 1990b) for members of the public and for workers, respectively.

For accidents, DOE has issued a series of orders specifying the requirements for emergency preparedness, including DOE Orders 5500.10, 5500.2B, 5500.3A, and 5500.4A (DOE 1991a,b,c, 1992). Each DOE site has also established an emergency management program, such as the one at Hanford (Westinghouse Hanford Co. 1994). Procedures and agreements among DOE, other federal agencies, and state agencies are in place to allow for effective response by all appropriate parties if a severe accident should occur.

Finally, it should be noted that shippers and carriers of radioactive material generally have a higher-than-average awareness of transport risk and prepare cargoes and drivers for such shipments accordingly. This preparation should have a twofold effect of reducing component/equipment failure and mitigating the "human error" contribution to accident causation. These effects were not given credit in the accident assessment but will act to limit accident occurrences in practice. 


\section{REFERENCES}

DOE: See U.S. Department of Energy.

Doty, S.R., et al., 1976, A Climatological Analysis of Pasquill Stability Categories Based on 'STAR' Summaries, National Climatic Center, National Oceanic and Atmospheric Administration, Asheville, N.C., April.

Fischer, L.E., et al., 1987, Shipping Container Response to Severe Highway and Railway Accident Conditions, NUREG/CR-4829, UCID-20733, prepared by Lawrence Livermore National Laboratory, Livermore, Calif., for U.S. Nuclear Regulatory Commission, Washington, D.C.

Folga, S.M., et al., 1996, High-Level Waste Inventory, Characteristics, Generation, and Facility Assessment for Treatment, Storage, and Disposal Alternatives Considered in the U.S. Department of Energy Waste Management Programmatic Environmental Impact Statement, ANL/EAD/TM-17, Argonne National Laboratory, Argonne, III.

ICRP: See International Commission on Radiological Protection.

International Commission on Radiological Protection, 1977, "Recommendations of the International Commission on Radiological Protection," ICRP publication 26, Annals of the ICRP 1(3), Pergamon Press, New York.

International Commission on Radiological Protection, 1991, "1990 Recommendations of the International Commission on Radiological Protection," ICRP publication 60, Annals of the ICRP 21(1-3), Pergamon Press, New York.

Johnson, P.E., et al., 1993a, HIGHWAY 3.1, An Enhanced Transportation Routing Model: Program Description, Methodology, and Revised User's Manual, ORNL/TM-12124, Oak Ridge National Laboratory, Oak Ridge, Tenn., March.

Johnson, P.E., et al., 1993b, INTERLINE 5.0, An Expanded Railroad Routing Model: Program Description, Methodology, and Revised User's Manual, ORNL/TM-12090, Oak Ridge National Laboratory, Oak Ridge, Tenn., March.

Madsen, M.M., and E.L. Wilmot, 1983, Truck Transportation of Radioactive Materials, SAND-821952C, Sandia National Laboratories, Albuquerque, N.M. 
Monette, F.A., et al., 1996a, Supplemental Information Related to Risk Assessment for the Off-Site Transportation of Transuranic Waste for the U.S. Department of Energy Waste Management Programmatic Environmental Impact Statement, ANL/EAD/TM-27, Argonne National Laboratory, Argonne, Ill.

Monette, F.A., et al., 1996b, Supplemental Information Related to Risk Assessment for the Off-Site Transportation of Low-Level Waste for the U.S. Department of Energy Waste Management Programmatic Environmental Impact Statement, ANL/EAD/TM-23, Argonne National Laboratory, Argonne, Ill.

Monette, F.A., et al., 1996c, Supplemental Information Related to Risk Assessment for the Off-Site Transportation of Low-Level Mixed Waste for the U.S. Department of Energy Waste Management Programmatic Environmental Impact Statement, ANL/EAD/TM-35, Argonne National Laboratory, Argonne, Ill.

Moore, R.L., et al., 1983, "Design Concept for a Defense High-Level Waste Shipping Cask-Truck," in Proceedings of the 7th International Symposium on Packaging and Transportation of Radioactive Materials, May.

Neuhauser, K.S., and F.L. Kanipe, 1993, RADTRAN 4, Volume II: Technical Manual, SAND89-2370, Sandia National Laboratories, Albuquerque, N.M., Aug.

NRC: See U.S. Nuclear Regulatory Commission.

Rao, R.K., et al., 1982, Non-Radiological Impacts of Transporting Radioactive Material, SAND811703, TTC-0236, Sandia National Laboratories, Albuquerque, N.M.

Saricks, C., and T. Kvitek, 1994, Longitudinal Review of State-Level Accident Statistics for Carriers of Interstate Freight, ANL/ESD/TM-68, Argonne National Laboratory, Argonne, Ill.

U.S. Department of Energy, 1986, Environmental Assessment: Yucca Mountain, Nevada, Nuclear Waste Policy Act, DOE/RW-0073, Office of Civilian Radioactive Waste Management, Washington, D.C., May.

U.S. Department of Energy, 1987a, Final Environmental Impact Statement: Disposal of Hanford Defense High-Level, Transuranic and Tank Wastes, DOE/EIS-0113, Washington, D.C., Dec.

U.S. Department of Energy, 1987b, Analysis of Radiation Doses from Operation of Postulated Commercial Spent Fuel Transportation Systems, DOE-CH/TPO-001, Pacific Northwest Laboratory, Richland, Wash., Nov. 
U.S. Department of Energy, 1988a, External Dose Rate Conversion Factors for Calculation of Dose to the Public, DOE/EH-0070, Office of Environment, Safety, and Health, Washington, D.C.

U.S. Department of Energy, 1988b, Internal Dose Conversion Factors for Calculation of Dose to the Public, DOE/EH-0071, Office of Environment, Safety, and Health, Washington, D.C.

U.S. Department of Energy, 1988c, "Radiation Protection for Occupational Workers," DOE Order 5480.11, Washington, D.C.

U.S. Department of Energy, 1990a, Supplemental Environmental Impact Statement, Waste Isolation Pilot Plant, DOE/EIS-0026-FS, Washington, D.C., Jan.

U.S. Department of Energy, 1990b, "Radiation Protection of the Public and the Environment," DOE Order 5400.5, Washington, D.C.

U.S. Department of Energy, 1991a, "Emergency Categories, Classes, and Notification and Reporting Requirements," DOE Order 5500.2B, Washington, D.C.

U.S. Department of Energy, 1991b, "Emergency Readiness Assurance Program," DOE Order 5500.10, Washington, D.C.

U.S. Department of Energy, 1991c, "Planning and Preparedness for Operational Emergencies," DOE Order 5500.3A, Washington, D.C.

U.S. Department of Energy, 1992, "Public Affairs Policy and Planning Requirements for Emergencies," DOE Order 5500.4A, Washington, D.C.

U.S. Department of Energy, 1996, Waste Management Programmatic Environmental Impact Statement for Managing Treatment, Storage, and Disposal of Radioactive and Hazardous Wastes, DOE/EIS-0200, Office of Waste Management, Washington, D.C.

U.S. Nuclear Regulatory Commission, 1977a, Final Environmental Statement on the Transportation of Radioactive Material by Air and Other Modes, NUREG-0170, Washington, D.C.

U.S. Nuclear Regulatory Commission, 1977b, Calculation of Annual Dose to Man From Routine Releases of Reactor Effluents for the Purpose of Evaluating Compliance with 10 CFR Part 50, Appendix I, Rev. I, Regulatory Guide 1.109, Washington, D.C.

Westinghouse Hanford Co., 1994, Emergency Plan, WHC-CM-4-1, Richland, Wash., Jan. 
Wilmot, E.L., 1981, Transportation Accident Scenarios for Commercial Spent Fuel, SAND80-2124, Sandia National Laboratories, Albuquerque, N.M.

Yuan, Y.C., et al., 1993, RISKIND-A Computer Program for Calculating Radiological Consequences and Health Risks from Transportation of Spent Nuclear Fuel, ANL/EAIS-6, Rev. 0, Argonne National Laboratory, Argonne, Ill., Feb. 
$A-1$

APPENDIX:

DETAILED COLLECTIVE RISK RESULTS BY ALTERNATIVE 
A-2 


\section{APPENDIX:}

\section{DETAILED COLLECTIVE RISK RESULTS BY ALTERNATIVE}

As described in the main body of this report, the RADTRAN 4 computer code (Neuhauser and Kanipe 1993) was used to calculate the collective population risks for routine and accident conditions for four HLW alternatives. The results of the collective risk assessment are summarized in Section 7 of the report. This appendix provides detailed results for each of the HLW alternatives considered.

The RADTRAN 4 population risk calculations take into account both the consequences and probabilities of potential exposure events. Thus, the accident risk values are referred to as "dose risk" because they incorporate the spectrum of accident probabilities. The collective population risk is a measure of the total radiological risk posed to society as a whole by the alternative being considered. As such, the collective population risks are used as the primary means of comparing the various alternatives in the WM PEIS.

The detailed results are presented in a series of tables organized into six sections, corresponding to the six HLW alternatives that represent different shipping options. The detailed results contain route summaries and "per-shipment" risk factors for each origin-destination pair considered by the particular alternative. The per-shipment risk factors can be used to estimate risks for alternatives that may differ from the ones presented here. 
A.1 Detailed Collective Risk Assessment Results for the HLW No Action Alternative

TABLE A.1-1 Summary of Route Information for the HLW No Action Alternative

\begin{tabular}{|c|c|c|c|c|c|}
\hline & \multirow[b]{2}{*}{ Mode/Route } & \multirow{2}{*}{$\begin{array}{c}\text { Distance } \\
\text { (mi) }\end{array}$} & \multicolumn{3}{|c|}{ Percentage in Zone } \\
\hline & & & Rural & Suburban & Urban \\
\hline \multicolumn{6}{|l|}{ Truck } \\
\hline Hanford Site & to Yucca Mountain, NV & 1,162 & 86.9 & 10.5 & 2.5 \\
\hline Savannah River & to Yucca Mountain, NV & 2,448 & 83.3 & 14.9 & 1.8 \\
\hline West Valley DP & to Yucca Mountain, NV & 2,407 & 83.9 & 14.1 & 2.0 \\
\hline \multicolumn{6}{|l|}{ Rail } \\
\hline Hanford Site & to Yucca Mountain, NV & 1,302 & 93.0 & 5.9 & 1.1 \\
\hline Savannah River & to Yucca Mountain, NV & 2,839 & 84.5 & 13.5 & 1.9 \\
\hline West Valley DP & to Yucca Mountain, NV & 2,540 & 78.0 & 18.0 & 4.0 \\
\hline
\end{tabular}

TABLE A.1-2 Number of Shipments and Total One-Way Shipment Distances for the HLW No Action Alternative

\begin{tabular}{|c|c|c|c|c|c|}
\hline & \multirow[b]{2}{*}{ Route } & \multicolumn{2}{|c|}{ Number of Shipments } & \multicolumn{2}{|c|}{ Total Mileage (mi) } \\
\hline & & Truck & Rail & Truck & Rail \\
\hline Hanford Site & to Yucca Mountain, NV & 15,000 & 3,000 & $1.74 \mathrm{E}+07$ & $3.91 E+06$ \\
\hline Savannah River & to Yucca Mountain, NV & 4,572 & 915 & $1.12 \mathrm{E}+07$ & $2.60 E+06$ \\
\hline West Valley DP & to Yucca Mountain, NV & 340 & 68 & $8.18 \mathrm{E}+05$ & $1.73 E+05$ \\
\hline Total & & 19,912 & 3,983 & $2.94 \mathrm{E}+07$ & $6.68 \mathrm{E}+06$ \\
\hline
\end{tabular}


TABLE A.1-3 Incident-Free Dose per Shipment (person-rem/shipment) for the HLW No Action Alternative

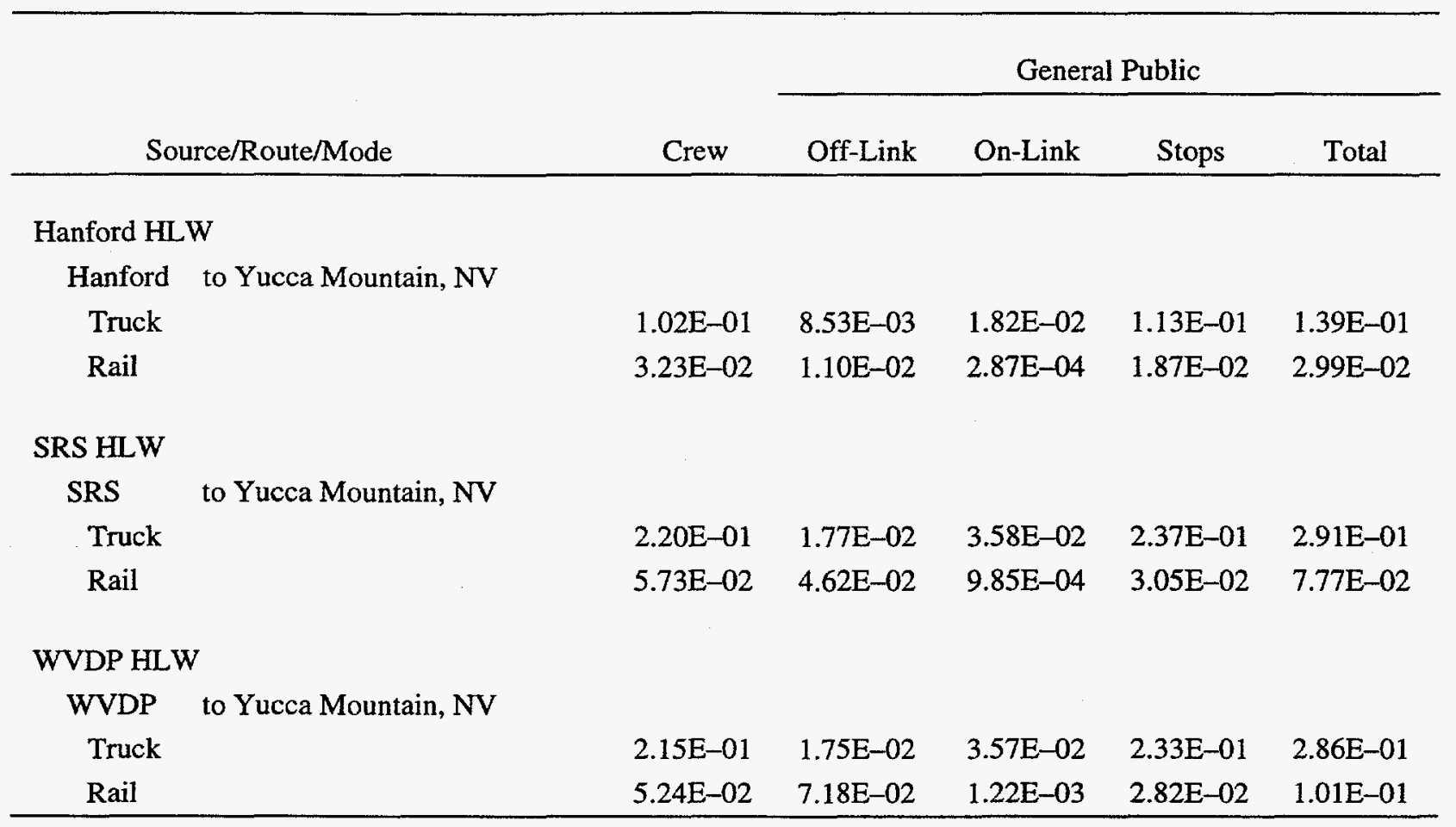

TABLE A.1-4 Accident Dose Risk per Shipment (person-rem/shipment) for the HLW No Action Alternative

\begin{tabular}{lcc}
\hline \multicolumn{1}{c}{ Source/Route } & Truck & Rail \\
\hline $\begin{array}{l}\text { Hanford HLW } \\
\text { Hanford Site } \quad \text { to Yucca Mountain, NV }\end{array}$ & $9.77 \mathrm{E}-06$ & $1.58 \mathrm{E}-06$ \\
$\begin{array}{l}\text { SRS HLW } \\
\text { Savannah River to Yucca Mountain, NV }\end{array}$ & $1.09 \mathrm{E}-04$ & $1.63 \mathrm{E}-05$ \\
$\begin{array}{l}\text { WVDP HLW } \\
\text { West Valley DP to Yucca Mountain, NV }\end{array}$ & $1.15 \mathrm{E}-04$ & $2.69 \mathrm{E}-04$ \\
\hline
\end{tabular}


TABLE A.1-5 Nonradiological Risk Factors per Shipment (fatalities/ shipment) for the HLW No Action Alternative

\begin{tabular}{llll}
\hline & Mode/Route & Emission & Accident \\
\hline & & & \\
Truck & & & \\
Hanford Site & to Yucca Mountain, NV & $9.50 \mathrm{E}-06$ & $6.50 \mathrm{E}-05$ \\
Savannah River & to Yucca Mountain, NV & $1.43 \mathrm{E}-05$ & $1.75 \mathrm{E}-04$ \\
West Valley DP & to Yucca Mountain, NV & $1.52 \mathrm{E}-05$ & $1.47 \mathrm{E}-04$ \\
& & & \\
Rail & & & \\
Hanford Site & to Yucca Mountain, NV & $5.90 \mathrm{E}-06$ & $2.72 \mathrm{E}-06$ \\
Savannah River & to Yucca Mountain, NV & $2.27 \mathrm{E}-05$ & $5.94 \mathrm{E}-06$ \\
West Valley DP & to Yucca Mountain, NV & $4.22 \mathrm{E}-05$ & $5.31 \mathrm{E}-06$ \\
\hline
\end{tabular}

TABLE A.1-6 Total Incident-Free Dose (person-rem) for the HLW No Action Alternative

\begin{tabular}{|c|c|c|c|c|c|}
\hline & \multirow[b]{2}{*}{ Route } & \multicolumn{2}{|c|}{ Truck } & \multicolumn{2}{|c|}{ Rail } \\
\hline & & Crew & Public & Crew & Public \\
\hline Hanford Site & to Yucca Mountain, NV & $1.52 \mathrm{E}+03$ & $2.09 \mathrm{E}+03$ & $9.70 \mathrm{E}+01$ & $8.98 \mathrm{E}+01$ \\
\hline Savannah River & to Yucca Mountain, NV & $1.01 \mathrm{E}+03$ & $1.33 E+03$ & $5.24 \mathrm{E}+01$ & $7.11 \mathrm{E}+01$ \\
\hline West Valley DP & to Yucca Mountain, NV & $7.32 \mathrm{E}+01$ & $9.74 \mathrm{E}+01$ & $3.56 \mathrm{E}+00$ & $6.88 \mathrm{E}+00$ \\
\hline Total & & $2.60 \mathrm{E}+03$ & $3.52 E+03$ & $1.53 \mathrm{E}+02$ & $1.68 \mathrm{E}+02$ \\
\hline
\end{tabular}

TABLE A.1-7 Total Accident Dose Risk (person-rem) for the HLW No Action Alternative

\begin{tabular}{lccc}
\hline & Route & Truck & Rail \\
\hline & & & \\
Hanford Site & to Yucca Mountain, NV & $1.46 \mathrm{E}-01$ & $4.74 \mathrm{E}-03$ \\
Savannah River & to Yucca Mountain, NV & $4.98 \mathrm{E}-01$ & $1.49 \mathrm{E}-02$ \\
West Valley DP & to Yucca Mountain, NV & $3.92 \mathrm{E}-02$ & $1.83 \mathrm{E}-03$ \\
\hline Total & & $6.83 \mathrm{E}-01$ & $2.15 \mathrm{E}-02$ \\
\hline
\end{tabular}


TABLE A.1-8 Expected Fatalities for the HLW No Action Alternative

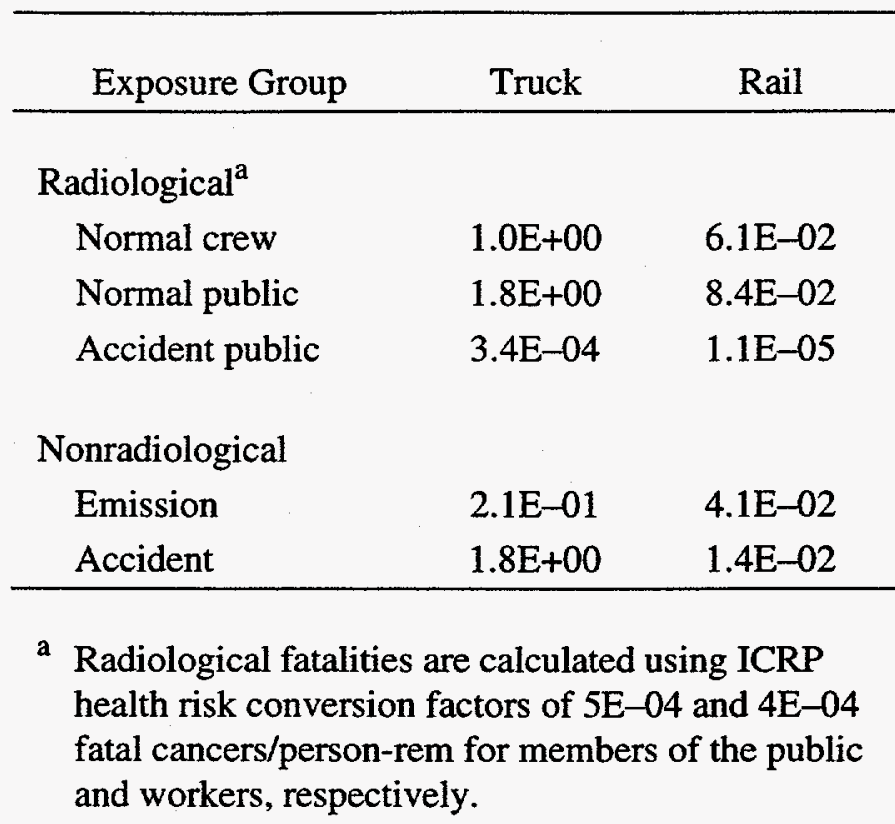

TABLE A.1-9 Expected Cancer Incidence for the HLW No Action Alternative

\begin{tabular}{lcc}
\hline \multicolumn{1}{c}{ Exposure Group } & Truck & Rail \\
\hline Radiological $^{\mathrm{a}}$ & & \\
Normal crew $_{\text {Normal public }}$ & $3.6 \mathrm{E}+00$ & $2.1 \mathrm{E}-01$ \\
Accident public & $6.0 \mathrm{E}+00$ & $2.9 \mathrm{E}-01$ \\
& $1.2 \mathrm{E}-03$ & $3.7 \mathrm{E}-05$ \\
Nonradiological & & \\
Emission & & \\
Accident & $2.1 \mathrm{E}-01$ & $4.1 \mathrm{E}-02$ \\
& $\mathrm{NA}$ & NA \\
\hline
\end{tabular}

a Radiological cancer incidences are calculated using ICRP health risk conversion factors of 1.7E-04 and 1.4E-04 fatal cancer cases/person-rem for members of the public and workers, respectively. 
TABLE A.1-10 Expected Genetic Effects for the HLW No Action Alternative

\begin{tabular}{lcc}
\hline Exposure Group & Truck & Rail \\
\hline Radiological $^{\mathrm{a}}$ & & \\
Normal crew $_{\text {Normal public }}$ & $1.6 \mathrm{E}-01$ & $9.2 \mathrm{E}-03$ \\
Accident public & $3.5 \mathrm{E}-01$ & $1.7 \mathrm{E}-02$ \\
& & $1.3 \mathrm{E}-05$ \\
Nonradiological & & \\
Emission & NA & NA \\
Accident & NA & NA \\
\hline
\end{tabular}

a Radiological genetic effects are calculated using ICRP health risk conversion factors of $1 E-04$ and $6 \mathrm{E}-05$ genetic effects/person-rem for members of the public and workers, respectively. 
A.2 Detailed Collective Risk Assessment Results for the HLW Decentralized Alternative

TABLE A.2-1 Summary of Route Information for the HLW Decentralized Alternative

\begin{tabular}{|c|c|c|c|c|c|}
\hline & & \multirow{2}{*}{$\begin{array}{c}\text { Distance } \\
(\mathrm{mi})\end{array}$} & \multicolumn{3}{|c|}{ Percentage in Zone } \\
\hline \multicolumn{2}{|c|}{ Mode/Route } & & Rural & Suburban & Urban \\
\hline \multicolumn{6}{|l|}{ Truck } \\
\hline Hanford Site & to Yucca Mountain, NV & 1,162 & 86.9 & 10.5 & 2.5 \\
\hline Savannah River & to Yucca Mountain, NV & 2,448 & 83.3 & 14.9 & 1.8 \\
\hline West Valley DP & to Yucca Mountain, NV & 2,407 & 83.9 & 14.1 & 2.0 \\
\hline INEL & to Yucca Mountain, NV & 746 & 83.6 & 13.0 & 3.4 \\
\hline \multicolumn{6}{|l|}{ Rail } \\
\hline Hanford Site & to Yucca Mountain, NV & 1,302 & 93.0 & 5.9 & 1.1 \\
\hline Savannah River & to Yucca Mountain, NV & 2,839 & 84.5 & 13.5 & 1.9 \\
\hline West Valley DP & to Yucca Mountain, NV & 2,540 & 78.0 & 18.0 & 4.0 \\
\hline INEL & to Yucca Mountain, NV & 756 & 92.8 & 5.9 & 1.3 \\
\hline
\end{tabular}

TABLE A.2-2 Number of Shipments and Total One-Way Shipment Distances for the HLW Decentralized Alternative

\begin{tabular}{|c|c|c|c|c|c|}
\hline & \multirow[b]{2}{*}{ Route } & \multicolumn{2}{|c|}{ Number of Shipments } & \multicolumn{2}{|c|}{ Total Mileage (mi) } \\
\hline & & Truck & Rail & Truck & Rail \\
\hline Hanford Site & to Yucca Mountain, NV & 15,000 & 3,000 & $1.74 \mathrm{E}+07$ & $3.91 E+06$ \\
\hline Savannah River & to Yucca Mountain, NV & 4,572 & 915 & $1.12 \mathrm{E}+07$ & $2.60 \mathrm{E}+06$ \\
\hline West Valley DP & to Yucca Mountain, NV & 340 & 68 & $8.18 \mathrm{E}+05$ & $1.73 \mathrm{E}+05$ \\
\hline INEL & to Yucca Mountain, NV & 1,700 & 340 & $1.27 \mathrm{E}+06$ & $2.57 \mathrm{E}+05$ \\
\hline Total & & 21,612 & 4,323 & $3.07 \mathrm{E}+07$ & $6.93 E+06$ \\
\hline
\end{tabular}


TABLE A.2-3 Incident-Free Dose per Shipment (person-rem/shipment) for the HLW Decentralized Alternative

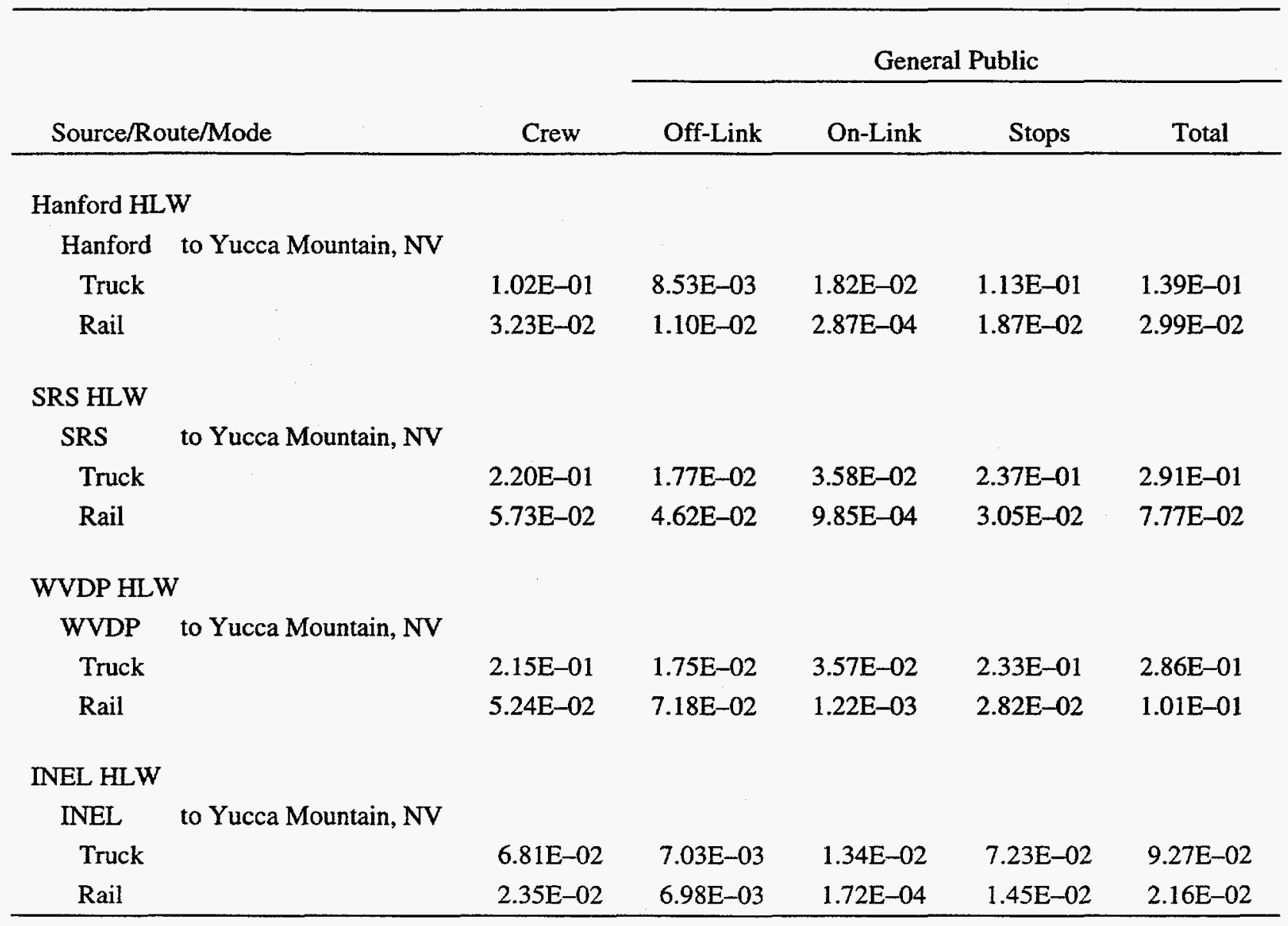


TABLE A.2-4 Accident Dose Risk per Shipment (person-rem/shipment) for the HLW Decentralized Alternative

\begin{tabular}{lcc}
\hline \multicolumn{1}{c}{ Source/Route } & Truck & Rail \\
\hline $\begin{array}{l}\text { Hanford HLW } \\
\text { Hanford Site }\end{array}$ to Yucca Mountain, NV & $9.77 \mathrm{E}-06$ & $1.58 \mathrm{E}-06$ \\
$\begin{array}{l}\text { SRS HLW } \\
\text { Savannah River to Yucca Mountain, NV }\end{array}$ & $1.09 \mathrm{E}-04$ & $1.63 \mathrm{E}-05$ \\
$\begin{array}{l}\text { WVDP HLW } \\
\text { West Valley DP } \text { to Yucca Mountain, NV }\end{array}$ & $1.15 \mathrm{E}-04$ & $2.69 \mathrm{E}-05$ \\
$\begin{array}{l}\text { INEL HLW } \\
\text { INEL }\end{array} \quad$ to Yucca Mountain, NV & $4.48 \mathrm{E}-07$ & $4.82 \mathrm{E}-08$ \\
\hline
\end{tabular}

TABLE A.2-5 Nonradiological Risk Factors per Shipment (fatalities/ shipment) for the HLW Decentralized Alternative

\begin{tabular}{|c|c|c|c|}
\hline \multicolumn{2}{|c|}{ Mode/Route } & \multirow{2}{*}{ Emission } & \multirow{2}{*}{ Accident } \\
\hline Truck & & & \\
\hline Hanford Site & to Yucca Mountain, NV & $9.50 \mathrm{E}-06$ & $6.50 \mathrm{E}-05$ \\
\hline Savannah River & to Yucca Mountain, NV & $1.43 \mathrm{E}-05$ & $1.75 \mathrm{E}-04$ \\
\hline West Valley DP & to Yucca Mountain, NV & $1.52 \mathrm{E}-05$ & $1.47 \mathrm{E}-04$ \\
\hline INEL & to Yucca Mountain, NV & $8.08 \mathrm{E}-06$ & $4.49 \mathrm{E}-05$ \\
\hline \multicolumn{4}{|l|}{ Rail } \\
\hline Hanford Site & to Yucca Mountain, NV & $5.90 \mathrm{E}-06$ & $2.72 \mathrm{E}-06$ \\
\hline Savannah River & to Yucca Mountain, NV & $2.27 \mathrm{E}-05$ & $5.94 \mathrm{E}-06$ \\
\hline West Valley DP & to Yucca Mountain, NV & $4.22 \mathrm{E}-05$ & $5.31 \mathrm{E}-06$ \\
\hline INEL & to Yucca Mountain, NV & $3.98 \mathrm{E}-06$ & $1.58 \mathrm{E}-06$ \\
\hline
\end{tabular}


TABLE A.2-6 Total Incident-Free Dose (person-rem) for the HLW Decentralized Alternative

\begin{tabular}{|c|c|c|c|c|c|}
\hline & \multirow[b]{2}{*}{ Route } & \multicolumn{2}{|c|}{ Truck } & \multicolumn{2}{|c|}{ Rail } \\
\hline & & Crew & Public & Crew & Public \\
\hline Hanford Site & to Yucca Mountain, NV & $1.52 \mathrm{E}+03$ & $2.09 \mathrm{E}+03$ & $9.70 \mathrm{E}+01$ & $8.98 \mathrm{E}+01$ \\
\hline Savannah River & to Yucca Mountain, NV & $1.01 E+03$ & $1.33 \mathrm{E}+03$ & $5.24 \mathrm{E}+01$ & $7.11 \mathrm{E}+01$ \\
\hline West Valley DP & to Yucca Mountain, NV & $7.32 \mathrm{E}+01$ & $9.74 \mathrm{E}+01$ & $3.56 \mathrm{E}+00$ & $6.88 \mathrm{E}+00$ \\
\hline INEL & to Yucca Mountain, NV & $1.16 \mathrm{E}+02$ & $1.58 \mathrm{E}+02$ & $7.98 \mathrm{E}+00$ & $7.36 \mathrm{E}+00$ \\
\hline Total & & $2.72 \mathrm{E}+03$ & $3.67 \mathrm{E}+03$ & $1.61 \mathrm{E}+02$ & $1.75 \mathrm{E}+02$ \\
\hline
\end{tabular}

TABLE A.2-7 Total Accident Dose Risk (person-rem) for the HLW Decentralized Alternative

\begin{tabular}{llll}
\hline & Route & Truck & Rail \\
\hline Hanford Site & to Yucca Mountain, NV & $1.46 \mathrm{E}-01$ & $4.74 \mathrm{E}-03$ \\
Savannah River & to Yucca Mountain, NV & $4.98 \mathrm{E}-01$ & $1.49 \mathrm{E}-02$ \\
West Valley DP & to Yucca Mountain, NV & $3.92 \mathrm{E}-02$ & $1.83 \mathrm{E}-03$ \\
INEL & to Yucca Mountain, NV & $7.61 \mathrm{E}-04$ & $1.64 \mathrm{E}-05$ \\
\hline & & & \\
Total & & $6.84 \mathrm{E}-01$ & $2.15 \mathrm{E}-02$ \\
\hline
\end{tabular}


TABLE A.2-8 Expected Fatalities for the HLW Decentralized Alternative

\begin{tabular}{|c|c|c|}
\hline Exposure Group & Truck & Rail \\
\hline \multicolumn{3}{|l|}{ Radiological $^{\mathrm{a}}$} \\
\hline Normal crew & $1.1 \mathrm{E}+00$ & $6.4 \mathrm{E}-02$ \\
\hline Normal public & $1.8 \mathrm{E}+00$ & $8.8 \mathrm{E}-02$ \\
\hline Accident public & $3.4 \mathrm{E}-04$ & $1.1 \mathrm{E}-05$ \\
\hline \multicolumn{3}{|l|}{ Nonradiological } \\
\hline Emission & $2.3 \mathrm{E}-01$ & $4.3 \mathrm{E}-02$ \\
\hline Accident & $1.9 \mathrm{E}+00$ & $1.5 \mathrm{E}-02$ \\
\hline \multicolumn{3}{|c|}{$\begin{array}{l}\text { Radiological fatalities are calculated } \\
\text { using ICRP health risk conversion } \\
\text { factors of } 5 E-04 \text { and } 4 \mathrm{E}-04 \text { fatal } \\
\text { cancers/person-rem for members of the } \\
\text { public and workers, respectively. }\end{array}$} \\
\hline
\end{tabular}

TABLE A.2-9 Expected Cancer Incidence for the HLW Decentralized Alternative

\begin{tabular}{|c|c|c|}
\hline Exposure Group & Truck & Rail \\
\hline \multicolumn{3}{|l|}{ Radiological $^{\text {a }}$} \\
\hline Normal crew & $3.8 \mathrm{E}+00$ & $2.3 \mathrm{E}-01$ \\
\hline Normal public & $6.2 E+00$ & $3.0 \mathrm{E}-01$ \\
\hline Accident public & $1.2 \mathrm{E}-03$ & $3.7 \mathrm{E}-05$ \\
\hline \multicolumn{3}{|l|}{ Nonradiological } \\
\hline Emission & $2.3 \mathrm{E}-01$ & $4.3 \mathrm{E}-02$ \\
\hline Accident & NA & NA \\
\hline \multicolumn{3}{|c|}{$\begin{array}{l}\text { Radiological cancer incidences are } \\
\text { calculated using ICRP health risk conver- } \\
\text { sion factors of } 1.7 \mathrm{E}-04 \text { and } 1.4 \mathrm{E}-04 \text { fatal } \\
\text { cancer cases/person-rem for members of the } \\
\text { public and workers, respectively. }\end{array}$} \\
\hline
\end{tabular}


TABLE A.2-10 Expected Genetic Effects for the HLW Decentralized Alternative

\begin{tabular}{lcc}
\hline Exposure Group & Truck & Rail \\
\hline & & \\
Radiological $^{\mathrm{a}}$ & & \\
Normal crew & $1.6 \mathrm{E}-01$ & $9.7 \mathrm{E}-03$ \\
Normal public & $3.7 \mathrm{E}-01$ & $1.8 \mathrm{E}-02$ \\
Accident public & $4.5 \mathrm{E}-05$ & $1.3 \mathrm{E}-06$ \\
Nonradiological & & \\
Emission & NA & NA \\
Accident & NA & NA \\
\hline
\end{tabular}

a Radiological genetic effects are calculated using ICRP health risk conversion factors of $1 \mathrm{E}-04$ and $6 \mathrm{E}-05$ genetic effects/person-rem for members of the public and workers, respectively. 


\section{A.3 Detailed Collective Risk Assessment Results for the HLW Regionalized 1 Alternative}

TABLE A.3-1 Summary of Route Information for the HLW

Regionalized 1 Alternative

\begin{tabular}{|c|c|c|c|c|c|}
\hline & & \multirow{2}{*}{$\begin{array}{c}\text { Distance } \\
\text { (mi) }\end{array}$} & \multicolumn{3}{|c|}{ Percentage in Zone } \\
\hline \multicolumn{2}{|c|}{ Mode/Route } & & Rural & Suburban & Urban \\
\hline \multicolumn{6}{|l|}{ Truck } \\
\hline Hanford Site & to Yucca Mountain, NV & 1,162 & 86.9 & 10.5 & 2.5 \\
\hline Savannah River & to Yucca Mountain, NV & 2,448 & 83.3 & 14.9 & 1.8 \\
\hline West Valley DP & to Savannah River & 883 & 70.3 & 28.5 & 1.2 \\
\hline INEL & to Yucca Mountain, NV & 746 & 83.6 & 13.0 & 3.4 \\
\hline \multicolumn{6}{|l|}{ Rail } \\
\hline Hanford Site & to Yucca Mountain, NV & 1,302 & 93.0 & 5.9 & 1.1 \\
\hline Savannah River & to Yucca Mountain, NV & 2,839 & 84.5 & 13.5 & 1.9 \\
\hline West Valley DP & to Savannah River & 1,217 & 62.8 & 32.4 & 4.9 \\
\hline INEL & to Yucca Mountain, NV & 756 & 92.8 & 5.9 & 1.3 \\
\hline
\end{tabular}

TABLE A.3-2 Number of Shipments and Total One-Way Shipment Distances for the HLW Regionalized 1 Alternative

\begin{tabular}{|c|c|c|c|c|c|}
\hline & \multirow[b]{2}{*}{ Route } & \multicolumn{2}{|c|}{ Number of Shipments } & \multicolumn{2}{|c|}{ Total Mileage (mi) } \\
\hline & & Truck & Rail & Truck & Rail \\
\hline Hanford Site & to Yucca Mountain, NV & 15,000 & 3,000 & $1.74 \mathrm{E}+07$ & $3.91 \mathrm{E}+06$ \\
\hline Savannah River & to Yucca Mountain, NV & 4,912 & 983 & $1.20 \mathrm{E}+07$ & $2.79 \mathrm{E}+06$ \\
\hline SRS HLW & & 4,572 & 915 & $1.12 \mathrm{E}+07$ & $2.60 \mathrm{E}+06$ \\
\hline WVDP HLW & & 340 & 68 & $8.32 E+05$ & $1.93 \mathrm{E}+05$ \\
\hline West Valley DP & to Savannah River & 340 & 68 & $3.00 \mathrm{E}+05$ & $8.27 \mathrm{E}+04$ \\
\hline INEL & to Yucca Mountain, NV & 1,700 & 340 & $1.27 \mathrm{E}+06$ & $2.57 \mathrm{E}+05$ \\
\hline Total & & 21,952 & 4,391 & $3.10 \mathrm{E}+07$ & $7.04 \mathrm{E}+06$ \\
\hline
\end{tabular}


TABLE A.3-3 Incident-Free Dose per Shipment (person-rem/shipment) for the HLW Regionalized 1 Alternative

\begin{tabular}{|c|c|c|c|c|c|c|}
\hline \multirow{2}{*}{\multicolumn{2}{|c|}{ Source/Route/Mode }} & \multirow[b]{2}{*}{ Crew } & \multicolumn{4}{|c|}{ General Public } \\
\hline & & & Off-Link & On-Link & Stops & Total \\
\hline \multicolumn{7}{|c|}{ Hanford HLW } \\
\hline \multicolumn{7}{|c|}{ Hanford to Yucca Mountain, NV } \\
\hline Truck & & $1.02 E-01$ & $8.53 \mathrm{E}-03$ & $1.82 \mathrm{E}-02$ & $1.13 \mathrm{E}-01$ & $1.39 \mathrm{E}-01$ \\
\hline Rail & & $3.23 \mathrm{E}-02$ & $1.10 \mathrm{E}-02$ & $2.87 \mathrm{E}-04$ & $1.87 \mathrm{E}-02$ & $2.99 \mathrm{E}-02$ \\
\hline \multicolumn{7}{|l|}{ SRS HLW } \\
\hline SRS & to Yucca Mountain, NV & & & & & \\
\hline Truck & & $2.20 \mathrm{E}-01$ & $1.77 \mathrm{E}-02$ & $3.58 \mathrm{E}-02$ & $2.37 \mathrm{E}-01$ & $2.91 \mathrm{E}-01$ \\
\hline Rail & & $5.73 \mathrm{E}-02$ & $4.62 \mathrm{E}-02$ & $9.85 \mathrm{E}-04$ & $3.05 \mathrm{E}-02$ & $7.77 \mathrm{E}-02$ \\
\hline \multicolumn{7}{|c|}{ WVDP HLW } \\
\hline WVDP & to Yucca Mountain, NV & & & & & \\
\hline Truck & & $8.88 \mathrm{E}-02$ & $8.49 \mathrm{E}-03$ & $1.34 \mathrm{E}-02$ & $8.56 \mathrm{E}-02$ & $1.07 \mathrm{E}-01$ \\
\hline Rail & & $3.09 \mathrm{E}-02$ & $4.86 \mathrm{E}-02$ & $8.43 \mathrm{E}-04$ & $1.80 \mathrm{E}-02$ & $6.75 \mathrm{E}-02$ \\
\hline SRS & to Yucca Mountain, NV & & & & & \\
\hline Truck & & $2.20 \mathrm{E}-01$ & $1.77 \mathrm{E}-02$ & $3.58 \mathrm{E}-02$ & $2.37 \mathrm{E}-01$ & 2/91E-01 \\
\hline Rail & & $5.73 \mathrm{E}-02$ & $4.62 \mathrm{E}-02$ & $9.85 \mathrm{E}-04$ & $3.05 \mathrm{E}-02$ & $7.77 \mathrm{E}-02$ \\
\hline \multicolumn{7}{|l|}{ INEL HLW } \\
\hline INEL & to Yucca Mountain, NV & & & & & \\
\hline Truck & & $6.81 E-02$ & $7.03 \mathrm{E}-03$ & $1.34 \mathrm{E}-02$ & $7.23 \mathrm{E}-02$ & $9.27 \mathrm{E}-02$ \\
\hline Rail & & $2.35 \mathrm{E}-02$ & $6.98 \mathrm{E}-03$ & $1.72 \mathrm{E}-04$ & $1.45 \mathrm{E}-02$ & $2.16 \mathrm{E}-02$ \\
\hline
\end{tabular}


TABLE A.3-4 Accident Dose Risk per Shipment (personrem/shipment) for the HLW Regionalized 1 Alternative

\begin{tabular}{|c|c|c|c|}
\hline \multicolumn{2}{|c|}{ Source/Route } & \multirow[t]{2}{*}{ Truck } & \multirow[t]{2}{*}{ Rail } \\
\hline Hanford HLW & & & \\
\hline Hanford Site & to Yucca Mountain, NV & $9.77 \mathrm{E}-06$ & $1.58 \mathrm{E}-06$ \\
\hline \multicolumn{4}{|l|}{ SRS HLW } \\
\hline Savannah River & to Yucca Mountain, NV & $1.09 \mathrm{E}-04$ & $1.63 \mathrm{E}-05$ \\
\hline \multicolumn{4}{|l|}{ WVDP HLW } \\
\hline West Valley DP & to Savannah River & $2.38 \mathrm{E}-05$ & $4.56 \mathrm{E}-06$ \\
\hline Savannah River & to Yucca Mountain, NV & $7.95 \mathrm{E}-05$ & $1.23 \mathrm{E}-05$ \\
\hline \multicolumn{4}{|l|}{ INEL HLW } \\
\hline INEL & to Yucca Mountain, NV & $4.48 \mathrm{E}-07$ & $4.82 \mathrm{E}-08$ \\
\hline
\end{tabular}

TABLE A.3-5 Nonradiological Risk Factors per Shipment (fatalities/shipment) for the HLW Regionalized 1 Alternative

\begin{tabular}{llll}
\hline \multicolumn{1}{c}{ Mode/Route } & Emission & Accident \\
\hline Truck & & & \\
Hanford Site & to Yucca Mountain, NV & $9.50 \mathrm{E}-06$ & $6.50 \mathrm{E}-05$ \\
Savannah River & to Yucca Mountain, NV & $1.43 \mathrm{E}-05$ & $1.75 \mathrm{E}-04$ \\
West Valley DP & to Savannah River & $3.28 \mathrm{E}-06$ & $6.60 \mathrm{E}-05$ \\
INEL & to Yucca Mountain, NV & $8.08 \mathrm{E}-06$ & $4.49 \mathrm{E}-05$ \\
Rail & & & \\
Hanford Site & to Yucca Mountain, NV & $5.90 \mathrm{E}-06$ & $2.72 \mathrm{E}-06$ \\
Savannah River & to Yucca Mountain, NV & $2.27 \mathrm{E}-05$ & $5.94 \mathrm{E}-06$ \\
West Valley DP & to Savannah River & $2.49 \mathrm{E}-05$ & $2.55 \mathrm{E}-06$ \\
INEL & to Yucca Mountain, NV & $3.98 \mathrm{E}-06$ & $1.58 \mathrm{E}-06$ \\
\hline
\end{tabular}


TABLE A.3-6 Total Incident-Free Dose (person-rem) for the HLW Regionalized 1 Alternative

\begin{tabular}{|c|c|c|c|c|c|}
\hline & \multirow[b]{2}{*}{ Route } & \multicolumn{2}{|c|}{ Truck } & \multicolumn{2}{|c|}{ Rail } \\
\hline & & Crew & Public & Crew & Public \\
\hline Hanford Site & to Yucca Mountain, NV & $1.52 \mathrm{E}+03$ & $2.09 E+03$ & $9.70 \mathrm{E}+01$ & $8.98 \mathrm{E}+01$ \\
\hline Savannah River & to Yucca Mountain, NV & $1.08 \mathrm{E}+03$ & $1.43 E+03$ & $5.63 E+01$ & $7.64 \mathrm{E}+01$ \\
\hline West Valley DP & to Savannah River & $3.02 \mathrm{E}+01$ & $3.65 \mathrm{E}+01$ & $2.10 \mathrm{E}+00$ & $4.59 \mathrm{E}+00$ \\
\hline INEL & to Yucca Mountain, NV & $1.16 \mathrm{E}+02$ & $1.58 \mathrm{E}+02$ & $7.98 \mathrm{E}+00$ & $7.36 \mathrm{E}+00$ \\
\hline Total & & $2.75 E+03$ & $3.71 \mathrm{E}+03$ & $1.63 E+02$ & $1.78 \mathrm{E}+02$ \\
\hline
\end{tabular}

TABLE A.3-7 Total Accident Dose Risk (person-rem) for the HLW Regionalized 1 Alternative

\begin{tabular}{llcc}
\hline & Route & Truck & Rail \\
\hline Hanford Site & to Yucca Mountain, NV & $1.46 \mathrm{E}-01$ & $4.74 \mathrm{E}-03$ \\
Savannah River & to Yucca Mountain, NV & $5.25 \mathrm{E}-01$ & $1.58 \mathrm{E}-02$ \\
West Valley DP & to Savannah River & $8.10 \mathrm{E}-03$ & $3.10 \mathrm{E}-04$ \\
INEL & to Yucca Mountain, NV & $7.61 \mathrm{E}-04$ & $1.64 \mathrm{E}-05$ \\
\hline & & & \\
Total & & $6.80 \mathrm{E}-01$ & $2.08 \mathrm{E}-02$ \\
\hline
\end{tabular}


TABLE A.3-8 Expected Fatalities for the HLW Regionalized 1 Alternative

\begin{tabular}{lcc}
\hline Exposure Group & Truck & Rail \\
\hline Radiological $^{\mathrm{a}}$ & & \\
Normal crew & $1.1 \mathrm{E}+00$ & $6.5 \mathrm{E}-02$ \\
Normal public & $1.9 \mathrm{E}+00$ & $8.9 \mathrm{E}-02$ \\
Accident public & $3.4 \mathrm{E}-04$ & $1.0 \mathrm{E}-05$ \\
Nonradiological & & \\
Emission & $2.3 \mathrm{E}-01$ & $4.3 \mathrm{E}-02$ \\
Accident & $1.9 \mathrm{E}+00$ & $1.5 \mathrm{E}-02$ \\
\hline
\end{tabular}

a Radiological fatalities are calculated using ICRP health risk conversion factors of 5E-04 and 4E-04 fatal cancers/person-rem for members of the public and workers, respectively.

TABLE A.3-9 Expected Cancer Incidence for the HLW Regionalized 1 Alternative

\begin{tabular}{lcc}
\hline Exposure Group & Truck & Rail \\
\hline Radiological $^{\mathrm{a}}$ & & \\
Normal crew & $3.9 \mathrm{E}+00$ & $2.3 \mathrm{E}-01$ \\
Normal public & $6.3 \mathrm{E}+00$ & $3.0 \mathrm{E}-01$ \\
Accident public & $1.2 \mathrm{E}-03$ & $3.5 \mathrm{E}-05$ \\
Nonradiological & & \\
Emission & $2.3 \mathrm{E}-01$ & $4.3 \mathrm{E}-02$ \\
Accident & $\mathrm{NA}$ & $\mathrm{NA}$ \\
\hline
\end{tabular}

a Radiological cancer incidences are calculated using ICRP health risk conversion factors of $1.7 \mathrm{E}-04$ and $1.4 \mathrm{E}-04$ fatal cancer cases/person-rem for members of the public and workers, respectively. 
TABLE A.3-10 Expected Genetic Effects for the HLW Regionalized 1 Alternative

\begin{tabular}{lcc}
\hline Exposure Group & Truck & Rail \\
\hline Radiological $^{\mathrm{a}}$ & & \\
Normal crew & $1.7 \mathrm{E}-01$ & $9.8 \mathrm{E}-03$ \\
Normal public & $3.7 \mathrm{E}-01$ & $1.8 \mathrm{E}-02$ \\
Accident public & $4.6 \mathrm{E}-05$ & $1.3 \mathrm{E}-06$ \\
Nonradiological & & \\
Emission & NA & NA \\
Accident & NA & NA \\
\hline
\end{tabular}

a Radiological genetic effects are calculated using ICRP health risk conversion factors of $1 \mathrm{E}-04$ and $6 \mathrm{E}-05$ genetic effects/person-rem for members of the public and workers, respectively. 
A.4 Detailed Collective Risk Assessment Results for the HLW Regionalized 2 Alternative

TABLE A.4-1 Summary of Route Information for the HLW

Regionalized 2 Alternative

\begin{tabular}{|c|c|c|c|c|c|}
\hline & & \multirow{2}{*}{$\begin{array}{c}\text { Distance } \\
\text { (mi) }\end{array}$} & \multicolumn{3}{|c|}{ Percentage in Zone } \\
\hline \multicolumn{2}{|c|}{ Mode/Route } & & Rural & Suburban & Urban \\
\hline \multicolumn{6}{|l|}{ Truck } \\
\hline Hanford Site & to Yucca Mountain, NV & 1,162 & 86.9 & 10.5 & 2.5 \\
\hline Savannah River & to Yucca Mountain, NV & 2,448 & 83.3 & 14.9 & 1.8 \\
\hline West Valley DP & to Hanford Site & 2,556 & 84.6 & 13.7 & 1.7 \\
\hline INEL & to Yucca Mountain, NV & 746 & 83.6 & 13.0 & 3.4 \\
\hline \multicolumn{6}{|l|}{ Rail } \\
\hline Hanford Site & to Yucca Mountain, NV & 1,302 & 93.0 & 5.9 & 1.1 \\
\hline Savannah River & to Yucca Mountain, NV & 2,839 & 84.5 & 13.5 & 1.9 \\
\hline West Valley DP & to Hanford Site & 2,654 & 78.3 & 18.0 & 3.7 \\
\hline INEL & to Yucca Mountain, NV & 756 & 92.8 & 5.9 & 1.3 \\
\hline
\end{tabular}

TABLE A.4-2 Number of Shipments and Total One-Way Shipment Distances for the HLW Regionalized 2 Alternative

\begin{tabular}{|c|c|c|c|c|c|}
\hline & \multirow[b]{2}{*}{ Route } & \multicolumn{2}{|c|}{ Number of Shipments } & \multicolumn{2}{|c|}{ Total Mileage (mi) } \\
\hline & & Truck & Rail & Truck & Rail \\
\hline Hanford Site & to Yucca Mountain, NV & 15,340 & 3,068 & $1.78 \mathrm{E}+07$ & $4.00 \mathrm{E}+06$ \\
\hline Hanford HLW & & 15,000 & 3,000 & $1.74 \mathrm{E}+07$ & $3.91 \mathrm{E}+06$ \\
\hline WVDP HLW & & 340 & 68 & $3.95 E+05$ & $8.85 \mathrm{E}+04$ \\
\hline Savannah River & to Yucca Mountain, NV & 4,572 & 915 & $1.12 \mathrm{E}+07$ & $2.60 \mathrm{E}+06$ \\
\hline West Valley DP & to Hanford Site & 340 & 68 & $8.69 \mathrm{E}+05$ & $1.80 \mathrm{E}+05$ \\
\hline INEL & to Yucca Mountain, NV & 1,700 & 340 & $1.27 \mathrm{E}+06$ & $2.57 \mathrm{E}+05$ \\
\hline Total & & 21,952 & 4,391 & $3.12 \mathrm{E}+07$ & $7.03 E+06$ \\
\hline
\end{tabular}


TABLE A.4-3 Incident-Free Dose per Shipment (person-rem/shipment) for the HLW Regionalized 2 Alternative

General Public

\begin{tabular}{|c|c|c|c|c|c|c|}
\hline \multirow{2}{*}{\multicolumn{2}{|c|}{ Source/Route/Mode }} & \multirow[b]{2}{*}{ Crew } & \\
\hline & & & Off-Link & On-Link & Stops & Total \\
\hline \multicolumn{7}{|c|}{ Hanford HLW } \\
\hline \multicolumn{7}{|c|}{ Hanford to Yucca Mountain, NV } \\
\hline Truck & & $1.02 \mathrm{E}-01$ & $8.53 \mathrm{E}-03$ & $1.82 \mathrm{E}-02$ & $1.13 \mathrm{E}-01$ & $1.39 \mathrm{E}-01$ \\
\hline Rail & & $3.23 E-02$ & $1.10 \mathrm{E}-02$ & $2.87 \mathrm{E}-04$ & $1.87 \mathrm{E}-02$ & $2.99 \mathrm{E}-02$ \\
\hline \multicolumn{7}{|l|}{ SRS HLW } \\
\hline SRS & to Yucca Mountain, NV & & & & & \\
\hline Truck & & $2.20 \mathrm{E}-01$ & $1.77 \mathrm{E}-02$ & $3.58 \mathrm{E}-02$ & $2.37 \mathrm{E}-01$ & $2.91 \mathrm{E}-01$ \\
\hline Rail & & $5.73 \mathrm{E}-02$ & $4.62 \mathrm{E}-02$ & $9.85 \mathrm{E}-04$ & $3.05 \mathrm{E}-02$ & 7.77E-02 \\
\hline \multicolumn{7}{|c|}{ WVDP HLW } \\
\hline \multicolumn{7}{|c|}{ WVDP to Yucca Mountain, NV } \\
\hline Truck & & $2.26 \mathrm{E}-01$ & $1.69 \mathrm{E}-02$ & $3.59 \mathrm{E}-02$ & $2.48 \mathrm{E}-01$ & $3.00 \mathrm{E}-01$ \\
\hline Rail & & $5.43 E-02$ & $7.19 \mathrm{E}-02$ & $1.25 \mathrm{E}-03$ & $2.91 \mathrm{E}-02$ & $1.02 \mathrm{E}-01$ \\
\hline \multicolumn{7}{|c|}{ Hanford to Yucca Mountain, NV } \\
\hline Truck & & $1.02 \mathrm{E}-01$ & $8.53 \mathrm{E}-03$ & $1.82 \mathrm{E}-02$ & $1.13 \mathrm{E}-01$ & $1.39 \mathrm{E}-01$ \\
\hline Rail & & $3.23 \mathrm{E}-02$ & $1.10 \mathrm{E}-02$ & $2.87 \mathrm{E}-04$ & $1.87 \mathrm{E}-02$ & $2.99 \mathrm{E}-02$ \\
\hline \multicolumn{7}{|l|}{ INEL HLW } \\
\hline INEL & to Yucca Mountain, NV & & & & & \\
\hline Truck & & $6.81 \mathrm{E}-02$ & $7.03 \mathrm{E}-03$ & $1.34 \mathrm{E}-02$ & $7.23 \mathrm{E}-02$ & $9.27 \mathrm{E}-02$ \\
\hline Rail & & $2.35 \mathrm{E}-02$ & $6.98 \mathrm{E}-03$ & $1.72 \mathrm{E}-04$ & $1.45 \mathrm{E}-02$ & $2.16 \mathrm{E}-02$ \\
\hline
\end{tabular}


TABLE A.4-4 Accident Dose Risk per Shipment (person-rem/ shipment) for the HLW Regionalized 2 Alternative

\begin{tabular}{|c|c|c|c|}
\hline \multicolumn{2}{|c|}{ Source/Route } & Truck & Rail \\
\hline \multicolumn{4}{|l|}{ Hanford HLW } \\
\hline Hanford Site & to Yucca Mountain, NV & $9.77 \mathrm{E}-06$ & $1.58 \mathrm{E}-06$ \\
\hline \multicolumn{4}{|l|}{ SRS HLW } \\
\hline Savannah River & to Yucca Mountain, NV & $1.09 \mathrm{E}-04$ & $1.63 \mathrm{E}-05$ \\
\hline \multicolumn{4}{|l|}{ WVDP HLW } \\
\hline West Valley DP & to Hanford Site & $1.17 \mathrm{E}-04$ & $2.76 \mathrm{E}-05$ \\
\hline Hanford Site & to Yucca Mountain, NV & $9.17 \mathrm{E}-06$ & $1.53 \mathrm{E}-06$ \\
\hline \multicolumn{4}{|l|}{ INEL HLW } \\
\hline INEL & to Yucca Mountain, NV & $4.48 \mathrm{E}-07$ & $4.82 \mathrm{E}-08$ \\
\hline
\end{tabular}

TABLE A.4-5 Nonradiological Risk Factors per Shipment (fatalities/shipment) for the HLW Regionalized 2 Alternative

\begin{tabular}{llll}
\hline \multicolumn{1}{c}{ Mode/Route } & Emission & Accident \\
\hline Truck & & & \\
Hanford Site & to Yucca Mountain, NV & $9.50 \mathrm{E}-06$ & $6.50 \mathrm{E}-05$ \\
Savannah River & to Yucca Mountain, NV & $1.43 \mathrm{E}-05$ & $1.75 \mathrm{E}-04$ \\
West Valley DP & to Hanford Site & $1.36 \mathrm{E}-05$ & $1.38 \mathrm{E}-04$ \\
INEL & to Yucca Mountain, NV & $8.08 \mathrm{E}-06$ & $4.49 \mathrm{E}-05$ \\
Rail & & & \\
Hanford Site & to Yucca Mountain, NV & $5.90 \mathrm{E}-06$ & $2.72 \mathrm{E}-06$ \\
Savannah River & to Yucca Mountain, NV & $2.27 \mathrm{E}-05$ & $5.94 \mathrm{E}-06$ \\
West Valley DP & to Hanford Site & $4.14 \mathrm{E}-05$ & $5.55 \mathrm{E}-06$ \\
INEL & to Yucca Mountain, NV & $3.98 \mathrm{E}-06$ & $1.58 \mathrm{E}-06$ \\
\hline
\end{tabular}


TABLE A.4-6 Total Incident-Free Dose (person-rem) for the HLW Regionalized 2 Alternative

\begin{tabular}{|c|c|c|c|c|c|}
\hline & \multirow[b]{2}{*}{ Route } & \multicolumn{2}{|c|}{ Truck } & \multicolumn{2}{|c|}{ Rail } \\
\hline & & Crew & Public & Crew & Public \\
\hline Hanford Site & to Yucca Mountain, NV & $1.56 \mathrm{E}+03$ & $2.14 \mathrm{E}+03$ & $9.92 E+01$ & $9.19 E+01$ \\
\hline Savannah River & to Yucca Mountain, NV & $1.01 \mathrm{E}+03$ & $1.33 E+03$ & $5.24 \mathrm{E}+01$ & $7.11 \mathrm{E}+01$ \\
\hline West Valley DP & to Hanford Site & $7.69 E+01$ & $1.02 \mathrm{E}+02$ & $3.69 \mathrm{E}+00$ & $6.95 E+00$ \\
\hline INEL & to Yucca Mountain, NV & $1.16 \mathrm{E}+02$ & $1.58 \mathrm{E}+02$ & $7.98 \mathrm{E}+00$ & $7.36 \mathrm{E}+00$ \\
\hline Total & & $2.76 \mathrm{E}+03$ & $3.73 E+03$ & $1.63 \mathrm{E}+02$ & $1.77 \mathrm{E}+02$ \\
\hline
\end{tabular}

TABLE A.4-7 Total Accident Dose Risk (person-rem) for the HLW Regionalized 2 Alternative

\begin{tabular}{llll}
\hline & Route & Truck & \multicolumn{1}{c}{ Rail } \\
\hline Hanford Site & to Yucca Mountain, NV & $1.50 \mathrm{E}-01$ & $4.84 \mathrm{E}-03$ \\
Savannah River & to Yucca Mountain, NV & $4.98 \mathrm{E}-01$ & $1.49 \mathrm{E}-02$ \\
West Valley DP & to Hanford Site & $3.96 \mathrm{E}-02$ & $1.88 \mathrm{E}-03$ \\
INEL & to Yucca Mountain, NV & $7.61 \mathrm{E}-04$ & $1.64 \mathrm{E}-05$ \\
\hline & & & \\
Total & & $6.88 \mathrm{E}-01$ & $2.17 \mathrm{E}-02$ \\
\hline
\end{tabular}


TABLE A.4-8 Expected Fatalities for the HLW Regionalized 2 Alternative

\begin{tabular}{lcc}
\hline Exposure Group & Truck & Rail \\
\hline Radiological $^{\mathrm{a}}$ & & \\
Normal crew & $1.1 \mathrm{E}+00$ & $6.5 \mathrm{E}-02$ \\
Normal public & $1.9 \mathrm{E}+00$ & $8.9 \mathrm{E}-02$ \\
Accident public & $3.4 \mathrm{E}-04$ & $1.1 \mathrm{E}-05$ \\
Nonradiological & & \\
Emission & $2.3 \mathrm{E}-01$ & $4.3 \mathrm{E}-02$ \\
Accident & $1.9 \mathrm{E}+00$ & $1.5 \mathrm{E}-02$ \\
\hline
\end{tabular}

${ }^{a}$. Radiological fatalities are calculated using ICRP health risk conversion factors of 5E-04 and 4E-04 fatal cancers/person-rem for members of the public and workers, respectively.

TABLE A.4-9 Expected Cancer Incidence for the HLW Regionalized 2 Alternative

\begin{tabular}{lcc}
\hline Exposure Group & Truck & Rail \\
\hline Radiological $^{\mathrm{a}}$ & & \\
Normal crew $_{\text {Normal public }}$ & $3.9 \mathrm{E}+00$ & $2.3 \mathrm{E}-01$ \\
Accident public & $1.2 \mathrm{E}-03$ & $3.7 \mathrm{E}-05$ \\
Nonradiological & & \\
Emission & $2.3 \mathrm{E}-01$ & $4.3 \mathrm{E}-02$ \\
Accident & NA & NA \\
\hline
\end{tabular}

a Radiological cancer incidences are calculated using ICRP health risk conversion factors of $1.7 \mathrm{E}-04$ and 1.4E-04 fatal cancer cases/person-rem for members of the public and workers, respectively. 
TABLE A.4-10 Expected Genetic

Effects for the HLW Regionalized 2

Alternative

\begin{tabular}{|c|c|c|}
\hline Exposure Group & Truck & Rail \\
\hline \multicolumn{3}{|l|}{ Radiological $^{\mathrm{a}}$} \\
\hline Normal crew & $1.7 \mathrm{E}-01$ & $9.8 \mathrm{E}-03$ \\
\hline Normal public & $3.7 \mathrm{E}-01$ & $1.8 \mathrm{E}-02$ \\
\hline Accident public & $4.5 \mathrm{E}-05$ & $1.3 \mathrm{E}-06$ \\
\hline \multicolumn{3}{|l|}{ Nonradiological } \\
\hline Emission & NA & NA \\
\hline Accident & NA & NA \\
\hline \multicolumn{3}{|c|}{$\begin{array}{l}\text { Radiological genetic effects are } \\
\text { calculated using ICRP health risk } \\
\text { conversion factors of } 1 \mathrm{E}-04 \text { and } 6 \mathrm{E}-05 \\
\text { genetic effects/person-rem for members } \\
\text { of the public and workers, respectively. }\end{array}$} \\
\hline
\end{tabular}




\section{A.5 Detailed Collective Risk Assessment Results for the HLW Centralized 1 Alternative}

TABLE A.5-1 Summary of Route Information for the HLW Centralized 1 Alternative

\begin{tabular}{|c|c|c|c|c|c|}
\hline & \multirow[b]{2}{*}{ Mode/Route } & \multirow{2}{*}{$\begin{array}{l}\text { Distance } \\
\text { (mi) }\end{array}$} & \multicolumn{3}{|c|}{ Percentage in Zone } \\
\hline & & & Rural & Suburban & Urban \\
\hline \multicolumn{6}{|l|}{ Truck } \\
\hline Hanford Site & to Yucca Mountain, NV & 1,162 & 86.9 & 10.5 & 2.5 \\
\hline Savannah River & to Hanford Site & 2,727 & 84.3 & 14.2 & 1.5 \\
\hline Savannah River & to Yucca Mountain, NV & 2,448 & 83.3 & 14.9 & 1.8 \\
\hline West Valley DP & to Hanford Site & 2,556 & 84.6 & 13.7 & 1.7 \\
\hline INEL & to Yucca Mountain, NV & 746 & 83.6 & 13.0 & 3.4 \\
\hline \multicolumn{6}{|l|}{ Rail } \\
\hline Hanford Site & to Yucca Mountain, NV & 1,302 & 93.0 & 5.9 & 1.1 \\
\hline Savannah River & to Hanford Site & 2,953 & 84.7 & 13.5 & 1.8 \\
\hline Savannah River & to Yucca Mountain, NV & 2,839 & 84.5 & 13.5 & 1.9 \\
\hline West Valley DP & to Hanford Site & 2,654 & 78.3 & 18.0 & 3.7 \\
\hline INEL & to Yucca Mountain, NV & 756 & 92.8 & 5.9 & 1.3 \\
\hline
\end{tabular}

TABLE A.5-2 Number of Shipments and Total One-Way Shipment Distances for the HLW Centralized 1 Alternative

\begin{tabular}{|c|c|c|c|c|c|}
\hline & \multirow[b]{2}{*}{ Route } & \multicolumn{2}{|c|}{ Number of Shipments } & \multicolumn{2}{|c|}{ Total Mileage (mi) } \\
\hline & & Truck & Rail & Truck & Rail \\
\hline Hanford Site & to Yucca Mountain, NV & 17,713 & 3,543 & $2.06 E+07$ & $4.61 \mathrm{E}+06$ \\
\hline Hanford HLW & & 15,000 & 3,000 & $1.74 \mathrm{E}+07$ & $3.91 \mathrm{E}+06$ \\
\hline SRS HLW & & 2,373 & 475 & $2.76 \mathrm{E}+06$ & $6.19 E+05$ \\
\hline WVDP HLW & & 340 & 68 & $3.95 \mathrm{E}+05$ & $8.85 E+04$ \\
\hline Savannah River & to Hanford Site & 2,373 & 475 & $6.47 \mathrm{E}+06$ & $1.40 \mathrm{E}+06$ \\
\hline Savannah River & to Yucca Mountain, NV & 2,199 & 440 & $5.38 \mathrm{E}+06$ & $1.25 E+06$ \\
\hline West Valley DP & to Hanford Site & 340 & 68 & $8.69 E+05$ & $1.80 \mathrm{E}+05$ \\
\hline INEL & to Yucca Mountain, NV & 1,700 & 340 & $1.27 \mathrm{E}+06$ & $2.57 E+05$ \\
\hline Total & & 24,325 & 4,866 & $3.46 \mathrm{E}+07$ & $7.70 E+06$ \\
\hline
\end{tabular}


TABLE A.5-3 Incident-Free Dose per Shipment (person-rem/shipment) for the HLW Centralized 1 Alternative

\begin{tabular}{|c|c|c|c|c|c|c|}
\hline \multirow{2}{*}{\multicolumn{2}{|c|}{ Source/Route/Mode }} & \multirow[b]{2}{*}{ Crew } & \multicolumn{4}{|c|}{ General Public } \\
\hline & & & Off-Link & On-Link & Stops & Total \\
\hline \multicolumn{7}{|c|}{ Hanford HLW } \\
\hline Hanford & to Yucca Mountain, NV & & & & & \\
\hline Truck & & $1.02 \mathrm{E}-01$ & $8.53 \mathrm{E}-03$ & $1.82 \mathrm{E}-02$ & $1.13 \mathrm{E}-01$ & $1.39 \mathrm{E}-01$ \\
\hline Rail & & $3.23 \mathrm{E}-02$ & $1.10 \mathrm{E}-02$ & $2.87 \mathrm{E}-04$ & $1.87 \mathrm{E}-02$ & $2.99 \mathrm{E}-02$ \\
\hline \multicolumn{7}{|l|}{ SRS HLW } \\
\hline SRS & to Hanford Site & & & & & \\
\hline Truck & & $2.42 \mathrm{E}-01$ & $1.76 \mathrm{E}-02$ & $3.75 \mathrm{E}-02$ & $2.64 \mathrm{E}-01$ & $3.19 \mathrm{E}-01$ \\
\hline Rail & & $5.91 \mathrm{E}-02$ & $4.62 \mathrm{E}-02$ & $1.01 \mathrm{E}-03$ & $3.14 \mathrm{E}-02$ & $7.86 \mathrm{E}-02$ \\
\hline Hanford & to Yucca Mountain, NV & & & & & \\
\hline Truck & & $1.02 \mathrm{E}-01$ & $8.53 \mathrm{E}-03$ & $1.82 \mathrm{E}-02$ & $1.13 \mathrm{E}-01$ & $1.39 \mathrm{E}-01$ \\
\hline Rail & & $3.23 \mathrm{E}-02$ & $1.10 \mathrm{E}-02$ & $2.87 \mathrm{E}-04$ & $1.87 \mathrm{E}-02$ & $2.99 \mathrm{E}-02$ \\
\hline SRS & to Yucca Mountain, NV & & & & & \\
\hline Truck & & $2.20 \mathrm{E}-01$ & $1.77 \mathrm{E}-02$ & $3.58 \mathrm{E}-02$ & $2.37 \mathrm{E}-01$ & $2.91 \mathrm{E}-01$ \\
\hline Rail & & $5.73 \mathrm{E}-02$ & $4.62 \mathrm{E}-02$ & $9.85 \mathrm{E}-04$ & $3.05 \mathrm{E}-02$ & $7.77 \mathrm{E}-02$ \\
\hline \multicolumn{7}{|c|}{ WVDP HLW } \\
\hline \multicolumn{7}{|l|}{ WVDP } \\
\hline Truck & & $2.26 \mathrm{E}-01$ & $1.69 \mathrm{E}-02$ & $3.59 \mathrm{E}-02$ & $2.48 \mathrm{E}-01$ & $3.00 \mathrm{E}-01$ \\
\hline Rail & & $5.43 \mathrm{E}-02$ & $7.19 \mathrm{E}-02$ & $1.25 \mathrm{E}-03$ & $2.91 \mathrm{E}-02$ & $1.02 \mathrm{E}-01$ \\
\hline Hanford & to Yucca Mountain, NV & & & & & \\
\hline Truck & & $1.02 \mathrm{E}-01$ & $8.53 \mathrm{E}-03$ & $1.82 \mathrm{E}-02$ & $1.13 \mathrm{E}-01$ & $1.39 \mathrm{E}-01$ \\
\hline Rail & & $3.23 E-02$ & $1.10 \mathrm{E}-02$ & $2.87 \mathrm{E}-04$ & $1.87 \mathrm{E}-02$ & $2.99 \mathrm{E}-02$ \\
\hline \multicolumn{7}{|c|}{ INEL HLW } \\
\hline INEL & to Yucca Mountain, NV & & & & & \\
\hline Truck & & $6.81 \mathrm{E}-02$ & $7.03 \mathrm{E}-03$ & $1.34 \mathrm{E}-02$ & $7.23 \mathrm{E}-02$ & $9.27 \mathrm{E}-02$ \\
\hline Rail & & $2.35 \mathrm{E}-02$ & $6.98 \mathrm{E}-03$ & $1.72 \mathrm{E}-04$ & $1.45 \mathrm{E}-02$ & $2.16 \mathrm{E}-02$ \\
\hline
\end{tabular}


TABLE A.5-4 Accident Dose Risk per Shipment (personrem/shipment) for the HLW Centralized 1 Alternative

\begin{tabular}{llll}
\hline \multicolumn{1}{c}{ Source/Route } & Truck & Rail \\
\hline & & & \\
$\begin{array}{c}\text { Hanford HLW } \\
\text { Hanford Site } \\
\text { SRS HLW }\end{array}$ & to Yucca Mountain, NV & $9.77 \mathrm{E}-06$ & $1.58 \mathrm{E}-06$ \\
$\begin{array}{l}\text { Savannah River } \\
\text { Hanford Site }\end{array}$ & to Hanford Site & $1.09 \mathrm{E}-04$ & $1.75 \mathrm{E}-05$ \\
$\begin{array}{l}\text { Savannah River } \\
\text { WVDP HLW }\end{array}$ & $\begin{array}{l}\text { to Yucca Mountain, NV } \\
\text { West Valley DP }\end{array}$ & $\begin{array}{l}1.52 \mathrm{E}-05 \\
\text { to Hanford Site }\end{array}$ & $2.49 \mathrm{E}-06$ \\
$\begin{array}{l}\text { Hanford Site } \\
\text { INEL HLW }\end{array}$ & to Yucca Mountain, NV & $9.17 \mathrm{E}-06$ & $1.53 \mathrm{E}-06$ \\
INEL & & & \\
\hline
\end{tabular}

TABLE A.5-5 Nonradiological Risk Factors per Shipment (fatalities/shipment) for the HLW Centralized 1 Alternative

\begin{tabular}{llll}
\hline \multicolumn{1}{c}{ Mode/Route } & Emission & Accident \\
\hline Truck & & & \\
Hanford Site & to Yucca Mountain, NV & $9.50 \mathrm{E}-06$ & $6.50 \mathrm{E}-05$ \\
Savannah River & to Hanford Site & $1.31 \mathrm{E}-05$ & $1.81 \mathrm{E}-04$ \\
Savannah River & to Yucca Mountain, NV & $1.43 \mathrm{E}-05$ & $1.75 \mathrm{E}-04$ \\
West Valley DP & to Hanford Site & $1.36 \mathrm{E}-05$ & $1.38 \mathrm{E}-04$ \\
INEL & to Yucca Mountain, NV & $8.08 \mathrm{E}-06$ & $4.49 \mathrm{E}-05$ \\
Rail & & & \\
Hanford Site & to Yucca Mountain, NV & $5.90 \mathrm{E}-06$ & $2.72 \mathrm{E}-06$ \\
Savannah River & to Hanford Site & $2.21 \mathrm{E}-05$ & $6.18 \mathrm{E}-06$ \\
Savannah River & to Yucca Mountain, NV & $2.27 \mathrm{E}-05$ & $5.94 \mathrm{E}-06$ \\
West Valley DP & to Hanford Site & $4.14 \mathrm{E}-05$ & $5.55 \mathrm{E}-06$ \\
INEL & to Yucca Mountain, NV & $3.98 \mathrm{E}-06$ & $1.58 \mathrm{E}-06$ \\
\hline
\end{tabular}


TABLE A.5-6 Total Incident-Free Dose (person-rem) for the HLW Centralized 1 Alternative

\begin{tabular}{|c|c|c|c|c|c|}
\hline & \multirow[b]{2}{*}{ Route } & \multicolumn{2}{|c|}{ Truck } & \multicolumn{2}{|c|}{ Rail } \\
\hline & & Crew & Public & Crew & Public \\
\hline Hanford Site & to Yucca Mountain, NV & $1.80 \mathrm{E}+03$ & $2.47 \mathrm{E}+03$ & $1.15 \mathrm{E}+02$ & $1.06 \mathrm{E}+02$ \\
\hline Savannah River & to Hanford Site & $5.73 E+02$ & $7.58 \mathrm{E}+02$ & $2.81 \mathrm{E}+01$ & $3.73 \mathrm{E}+01$ \\
\hline Savannah River & to Yucca Mountain, NV & $4.84 \mathrm{E}+02$ & $6.39 \mathrm{E}+02$ & $2.52 \mathrm{E}+01$ & $3.42 \mathrm{E}+01$ \\
\hline West Valley DP & to Hanford Site & $7.69 \mathrm{E}+01$ & $1.02 \mathrm{E}+02$ & $3.69 E+00$ & $6.95 \mathrm{E}+00$ \\
\hline INEL & to Yucca Mountain, NV & $1.16 \mathrm{E}+02$ & $1.58 \mathrm{E}+02$ & $7.98 \mathrm{E}+00$ & $7.36 \mathrm{E}+00$ \\
\hline Total & & $3.05 \mathrm{E}+03$ & $4.12 E+03$ & $1.80 \mathrm{E}+02$ & $1.92 \mathrm{E}+02$ \\
\hline
\end{tabular}

TABLE A.5-7 Total Accident Dose Risk (person-rem) for the HLW Centralized 1 Alternative

\begin{tabular}{llcc}
\hline & Route & Truck & \multicolumn{1}{c}{ Rail } \\
\hline Hanford Site & to Yucca Mountain, NV & $1.86 \mathrm{E}-01$ & $6.03 \mathrm{E}-03$ \\
Savannah River & to Hanford Site & $2.59 \mathrm{E}-01$ & $8.29 \mathrm{E}-03$ \\
Savannah River & to Yucca Mountain, NV & $2.39 \mathrm{E}-01$ & $7.18 \mathrm{E}-03$ \\
West Valley DP & to Hanford Site & $3.96 \mathrm{E}-02$ & $1.88 \mathrm{E}-03$ \\
INEL & to Yucca Mountain, NV & $7.61 \mathrm{E}-04$ & $1.64 \mathrm{E}-05$ \\
\hline & & & \\
Total & & & \\
\hline
\end{tabular}


TABLE A.5-8 Expected Fatalities for the HLW Centralized 1 Alternative

\begin{tabular}{lll}
\hline Exposure Group & Truck & Rail \\
\hline Radiological $^{\mathrm{a}}$ & & \\
Normal crew & $1.2 \mathrm{E}+00$ & $7.2 \mathrm{E}-02$ \\
Normal public & $2.1 \mathrm{E}+00$ & $9.6 \mathrm{E}-02$ \\
Accident public & $3.6 \mathrm{E}-04$ & $1.2 \mathrm{E}-05$ \\
Nonradiological & & \\
Emission & $2.5 \mathrm{E}-01$ & $4.6 \mathrm{E}-02$ \\
Accident & $2.1 \mathrm{E}+00$ & $1.6 \mathrm{E}-02$ \\
\hline
\end{tabular}

a Radiological fatalities are calculated using ICRP health risk conversion factors of $5 \mathrm{E}-04$ and $4 \mathrm{E}-04$ fatal cancers/ person-rem for members of the public and workers, respectively.

TABLE A.5-9 Expected Cancer Incidence for the HLW Centralized 1 Alternative

\begin{tabular}{lcc}
\hline Exposure Group & Truck & Rail \\
\hline Radiological $^{\mathrm{a}}$ & & \\
Normal crew & $4.3 \mathrm{E}+00$ & $2.5 \mathrm{E}-01$ \\
Normal public & $7.0 \mathrm{E}+00$ & $3.3 \mathrm{E}-01$ \\
Accident public & $1.2 \mathrm{E}-03$ & $4.0 \mathrm{E}-05$ \\
Nonradiological & & \\
Emission & $2.5 \mathrm{E}-01$ & $4.6 \mathrm{E}-02$ \\
Accident & NA & NA \\
\hline
\end{tabular}

a Radiological cancer incidences are calculated using ICRP health risk conversion factors of $1.7 \mathrm{E}-04$ and 1.4E-04 fatal cancer cases/person-rem for members of the public and workers, respectively. 
TABLE A.5-10 Expected Genetic Effects for the HLW Centralized 1 Alternative

\begin{tabular}{lcc}
\hline Exposure Group & Truck & Rail \\
\hline Radiological $^{\mathrm{a}}$ & & \\
Normal crew $_{\text {Normal public }}$ & $1.8 \mathrm{E}-01$ & $1.1 \mathrm{E}-02$ \\
Accident public & $4.1 \mathrm{E}-01$ & $1.9 \mathrm{E}-02$ \\
Nonradiological & & $1.4 \mathrm{E}-06$ \\
Emission & NA & NA \\
Accident & NA & NA \\
\hline
\end{tabular}

a Radiological genetic effects are calculated using ICRP health risk conversion factors of $1 \mathrm{E}-04$ and $6 \mathrm{E}-05$ genetic effects/personrem for members of the public and workers, respectively. 
A.6 Detailed Collective Risk Assessment Results for the HLW Centralized 2 Alternative

TABLE A.6-1 Summary of Route Information for the HLW

Centralized 2 Alternative

\begin{tabular}{|c|c|c|c|c|c|}
\hline & & \multirow[b]{2}{*}{$\begin{array}{c}\text { Distance } \\
\text { (mi) }\end{array}$} & \multicolumn{3}{|c|}{ Percentage in Zone } \\
\hline \multicolumn{2}{|c|}{ Mode/Route } & & Rural & Suburban & Urban \\
\hline \multicolumn{6}{|l|}{ Truck } \\
\hline Hanford Site & to Yucca Mountain, NV & 1,162 & 86.9 & 10.5 & 2.5 \\
\hline Savannah River & to Hanford Site & 2,727 & 84.3 & 14.2 & 1.5 \\
\hline West Valley DP & to Hanford Site & 2,556 & 84.6 & 13.7 & 1.7 \\
\hline INEL & to Hanford Site & 599 & 91.3 & 7.6 & 1.1 \\
\hline \multicolumn{6}{|l|}{ Rail } \\
\hline Hanford Site & to Yucca Mountain, NV & 1,302 & 93.0 & 5.9 & 1.1 \\
\hline Savannah River & to Hanford Site & 2,953 & 84.7 & 13.5 & 1.8 \\
\hline West Valley DP & to Hanford Site & 2,654 & 78.3 & 18.0 & 3.7 \\
\hline INEL & to Hanford Site & 658 & 91.4 & 7.1 & 1.4 \\
\hline
\end{tabular}

TABLE A.6-2 Number of Shipments and Total One-Way Shipment Distances for the HLW Centralized 2 Alternative

\begin{tabular}{|c|c|c|c|c|c|}
\hline & \multirow[b]{2}{*}{ Route } & \multicolumn{2}{|c|}{ Number of Shipments } & \multicolumn{2}{|c|}{ Total Mileage (mi) } \\
\hline & & Truck & Rail & Truck & Rail \\
\hline Hanford Site & to Yucca Mountain, NV & 21,612 & 4,323 & $2.51 \mathrm{E}+07$ & $5.63 E+06$ \\
\hline Hanford HLW & & 15,000 & 3,000 & $1.74 \mathrm{E}+07$ & $3.91 E+06$ \\
\hline SRS HLW & & 4,572 & 915 & $5.31 \mathrm{E}+06$ & $1.19 E+06$ \\
\hline WVDP HLW & & 340 & 68 & $3.95 \mathrm{E}+05$ & $8.85 \mathrm{E}+04$ \\
\hline INEL HLW & & 1,700 & 340 & $1.98 \mathrm{E}+06$ & $4.43 \mathrm{E}+05$ \\
\hline Savannah River & to Hanford Site & 4,572 & 915 & $1.25 \mathrm{E}+07$ & $2.70 E+06$ \\
\hline West Valley DP & to Hanford Site & 340 & 68 & $8.69 E+05$ & $1.80 \mathrm{E}+05$ \\
\hline INEL & to Hanford Site & 1,700 & 340 & $1.02 E+06$ & $2.24 \mathrm{E}+05$ \\
\hline Total & & 28,224 & 5,646 & $3.95 E+07$ & $8.74 \mathrm{E}+06$ \\
\hline
\end{tabular}


TABLE A.6-3 Incident-Free Dose per Shipment (person-rem/shipment) for the HLW Centralized 2 Alternative

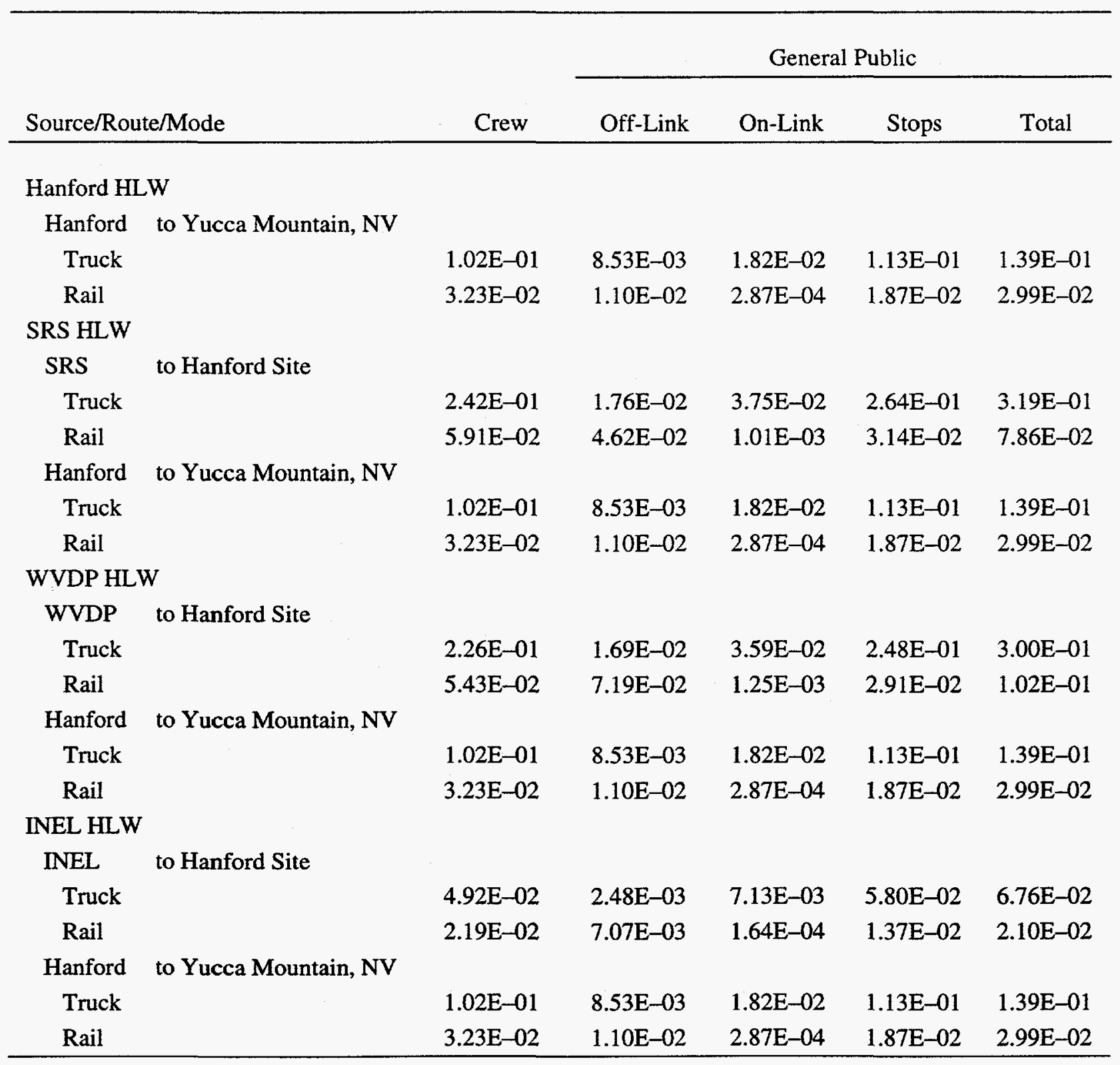


TABLE A.6-4 Accident Dose Risk per Shipment (personrem/shipment) for the HLW Centralized 2 Alternative

\begin{tabular}{|c|c|c|c|}
\hline \multicolumn{2}{|c|}{ Source/Route } & \multirow[t]{2}{*}{ Truck } & \multirow[t]{2}{*}{ Rail } \\
\hline Hanford HLW & & & \\
\hline Hanford Site & to Yucca Mountain, NV & $9.77 \mathrm{E}-06$ & $1.58 \mathrm{E}-06$ \\
\hline \multicolumn{4}{|l|}{ SRS HLW } \\
\hline Savannah River & to Hanford Site & $1.09 \mathrm{E}-04$ & $1.75 \mathrm{E}-05$ \\
\hline Hanford Site & to Yucca Mountain, NV & $1.52 \mathrm{E}-05$ & $2.49 \mathrm{E}-06$ \\
\hline \multicolumn{4}{|l|}{ WVDP HLW } \\
\hline West Valley DP & to Hanford Site & $1.17 \mathrm{E}-04$ & $2.76 \mathrm{E}-05$ \\
\hline Hanford Site & to Yucca Mountain, NV & $9.17 \mathrm{E}-06$ & $1.53 \mathrm{E}-06$ \\
\hline \multicolumn{4}{|l|}{ INEL HLW } \\
\hline INEL & to Hanford Site & $2.70 \mathrm{E}-07$ & $7.39 \mathrm{E}-08$ \\
\hline Hanford Site & to Yucca Mountain, NV & $6.18 \mathrm{E}-07$ & $9.96 \mathrm{E}-08$ \\
\hline
\end{tabular}

TABLE A.6-5 Nonradiological Risk Factors per Shipment (fatalities/shipment) for the HLW Centralized 2 Alternative

\begin{tabular}{llll}
\hline \multicolumn{1}{c}{ Mode/Route } & Emission & Accident \\
\hline Truck & & & \\
Hanford Site & to Yucca Mountain, NV & $9.50 \mathrm{E}-06$ & $6.50 \mathrm{E}-05$ \\
Savannah River & to Hanford Site & $1.31 \mathrm{E}-05$ & $1.81 \mathrm{E}-04$ \\
West Valley DP & to Hanford Site & $1.36 \mathrm{E}-05$ & $1.38 \mathrm{E}-04$ \\
INEL & to Hanford Site & $2.19 \mathrm{E}-06$ & $3.07 \mathrm{E}-05$ \\
Rail & & & \\
Hanford Site & to Yucca Mountain, NV & $5.90 \mathrm{E}-06$ & $2.72 \mathrm{E}-06$ \\
Savannah River & to Hanford Site & $2.21 \mathrm{E}-05$ & $6.18 \mathrm{E}-06$ \\
West Valley DP & to Hanford Site & $4.14 \mathrm{E}-05$ & $5.55 \mathrm{E}-06$ \\
INEL & to Hanford Site & $3.98 \mathrm{E}-06$ & $1.38 \mathrm{E}-06$ \\
\hline
\end{tabular}


TABLE A.6-6 Total Incident-Free Dose (person-rem) for the HLW Centralized 2 Alternative

\begin{tabular}{|c|c|c|c|c|c|}
\hline & \multirow[b]{2}{*}{ Route } & \multicolumn{2}{|c|}{ Truck } & \multicolumn{2}{|c|}{ Rail } \\
\hline & & Crew & Public & Crew & Public \\
\hline Hanford Site & to Yucca Mountain, NV & $2.20 \mathrm{E}+03$ & $3.01 E+03$ & $1.40 \mathrm{E}+02$ & $1.29 E+02$ \\
\hline Savannah River & to Hanford Site & $1.10 \mathrm{E}+03$ & $1.46 \mathrm{E}+03$ & $5.41 \mathrm{E}+01$ & $7.19 E+01$ \\
\hline West Valley DP & to Hanford Site & $7.69 \mathrm{E}+01$ & $1.02 \mathrm{E}+02$ & $3.69 \mathrm{E}+00$ & $6.95 \mathrm{E}+00$ \\
\hline INEL & to Hanford Site & $8.36 \mathrm{E}+01$ & $1.15 \mathrm{E}+02$ & $7.44 \mathrm{E}+00$ & $7.13 \mathrm{E}+00$ \\
\hline Total & & $3.46 \mathrm{E}+03$ & $4.69 \mathrm{E}+03$ & $2.05 \mathrm{E}+02$ & $2.15 \mathrm{E}+02$ \\
\hline
\end{tabular}

TABLE A.6-7 Total Accident Dose Risk (person-rem) for the HLW Centralized 2 Alternative

\begin{tabular}{llll}
\hline & Route & Truck & \multicolumn{1}{c}{ Rail } \\
\hline Hanford Site & to Yucca Mountain, NV & $2.20 \mathrm{E}-01$ & $7.16 \mathrm{E}-03$ \\
Savannah River & to Hanford Site & $5.00 \mathrm{E}-01$ & $1.60 \mathrm{E}-02$ \\
West Valley DP & to Hanford Site & $3.96 \mathrm{E}-02$ & $1.88 \mathrm{E}-03$ \\
INEL & to Hanford Site & $4.58 \mathrm{E}-04$ & $2.51 \mathrm{E}-05$ \\
\hline & & & \\
Total & & $7.60 \mathrm{E}-01$ & $2.50 \mathrm{E}-02$ \\
\hline
\end{tabular}


TABLE A.6-8 Expected Fatalities for the HLW Centralized 2 Alternative

\begin{tabular}{lll}
\hline Exposure Group & Truck & Rail \\
\hline Radiological $^{\mathrm{a}}$ & & \\
$\quad$ Normal crew & $1.4 \mathrm{E}+00$ & $8.2 \mathrm{E}-02$ \\
Normal public & $2.3 \mathrm{E}+00$ & $1.1 \mathrm{E}-01$ \\
Accident public & $3.8 \mathrm{E}-04$ & $1.3 \mathrm{E}-05$ \\
Nonradiological & & \\
Emission & $2.7 \mathrm{E}-01$ & $5.0 \mathrm{E}-02$ \\
Accident & $2.3 \mathrm{E}+00$ & $1.8 \mathrm{E}-02$ \\
\hline
\end{tabular}

a Radiological fatalities are calculated using ICRP health risk conversion factors of 5E-04 and 4E-04 fatal cancers/person-rem for members of the public and workers, respectively.

TABLE A.6-9 Expected Cancer Incidence for the HLW Centralized 2 Alternative

\begin{tabular}{lcc}
\hline Exposure Group & Truck & Rail \\
\hline Radiological $^{\mathrm{a}}$ & & \\
Normal crew & $4.8 \mathrm{E}+00$ & $2.9 \mathrm{E}-01$ \\
Normal public & $8.0 \mathrm{E}+00$ & $3.7 \mathrm{E}-01$ \\
Accident public & $1.3 \mathrm{E}-03$ & $4.3 \mathrm{E}-05$ \\
Nonradiological & & \\
Emission & $2.7 \mathrm{E}-01$ & $5.0 \mathrm{E}-02$ \\
Accident & NA & NA \\
\hline
\end{tabular}

a Radiological cancer incidences are calculated using ICRP health risk conversion factors of $1.7 \mathrm{E}-04$ and $1.4 \mathrm{E}-04$ fatal cancer cases/person-rem for members of the public and workers, respectively. 
TABLE A.6-10 Expected Genetic

Effects for the HLW Centralized 2

Alternative

\begin{tabular}{lll}
\hline Exposure Group & Truck & Rail \\
\hline Radiological $^{\mathrm{a}}$ & & \\
Normal crew & $2.1 \mathrm{E}-01$ & $1.2 \mathrm{E}-02$ \\
Normal public & $4.7 \mathrm{E}-01$ & $2.2 \mathrm{E}-02$ \\
Accident public & $5.0 \mathrm{E}-05$ & $1.5 \mathrm{E}-06$ \\
Nonradiological & & \\
Emission & NA & NA \\
Accident & NA & NA \\
\hline
\end{tabular}

a Radiological genetic effects are calculated using ICRP health risk conversion factors of $1 \mathrm{E}-04$ and $6 \mathrm{E}-05$ genetic effects/person-rem for members of the public and workers, respectively. 